RAFAELLA ALMEIDA LIMA NUNES

\author{
APLICAÇÃO DE TÉCNICAS MOLECULARES NO DIAGNÓSTICO \\ LABORATORIAL COMPLEMENTAR DAS INFECÇÕES VIRAIS DO \\ SISTEMA NERVOSO CENTRAL NO HOSPITAL UNIVERSITÁRIO DA USP
}

Dissertação apresentada ao Programa de PósGraduação em Microbiologia do Instituto de Ciências Biomédicas da Universidade de São Paulo, para obtenção do Título de Mestre em Ciências. 
RAFAELLA ALMEIDA LIMA NUNES

\section{APLICAÇÃO DE TÉCNICAS MOLECULARES NO DIAGNÓSTICO \\ LABORATORIAL COMPLEMENTAR DAS INFECÇÕES VIRAIS DO \\ SISTEMA NERVOSO CENTRAL NO HOSPITAL UNIVERSITÁRIO DA USP}

Dissertação apresentada ao Programa de PósGraduação em Microbiologia do Instituto de Ciências Biomédicas da Universidade de São Paulo, para obtenção do Título de Mestre em Ciências.

Área de concentração: Microbiologia.

Orientadora: Profa. Dra. Charlotte Marianna Hársi.

Versão corrigida. A versão original eletrônica encontra-se disponível tanto na Biblioteca do ICB quanto na Biblioteca Digital de Teses e Dissertações da USP (BDTD). 
DADOS DE CATALOGAÇÃO NA PUBLICAÇÃO (CIP)

Serviço de Biblioteca e Informação Biomédica do

Instituto de Ciências Biomédicas da Universidade de São Paulo

구 reprodução total

Nunes, Rafaella Almeida Lima.

Aplicação de técnicas moleculares no diagnóstico laboratorial complementar das infecções virais do sistema nervoso central no Hospital Universitário da USP / Rafaella Almeida Lima Nunes. -- São Paulo, 2013.

Orientador: Profa. Dra. Charlotte Marianna Harsi.

Dissertação (Mestrado) - Universidade de São Paulo. Instituto de Ciências Biomédicas. Departamento de Microbiologia. Área de concentração: Microbiologia. Linha de pesquisa: Virologia.

Versão do título para o inglês: Molecular techniques application for the complementary laboratory diagnosis of viral infections of the central nervous system at the University Hospital of USP.

1. Meningite 2. Meningoencefalite 3 . Reação em cadeia da polimerase 4. Adenovírus humanos 5. Enterovírus humanos 6. Herpesvírus humanos I. Harsi, Profa. Dra. Charlotte Marianna II. Universidade de São Paulo. Instituto de Ciências Biomédicas. Programa de Pós-Graduação em Microbiologia III. Título. 
Candidato(a): $\quad$ Rafaella Almeida Lima Nunes.

Título da Dissertação: Aplicação de técnicas moleculares no diagnóstico laboratorial complementar das infecções virais do sistema nervoso central no Hospital Universitário da USP.

Orientador(a): $\quad$ Profa. Dra. Charlotte Marianna Harsi.

A Comissão Julgadora dos trabalhos de Defesa da Dissertação de Mestrado, em sessão pública realizada a .................................................., considerou

( ) Aprovado(a) ( ) Reprovado(a)

Examinador(a): Assinatura:

Nome:

Instituição:

Examinador(a): Assinatura:

Nome:

Instituição:

Presidente: Assinatura:

Nome:

Instituição: 


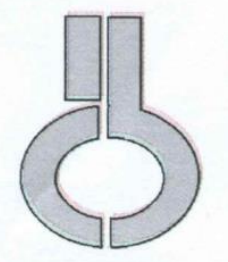

UNIVERSIDADE DE SÃO PAULO

\section{INSTITUTO DE CIÊNCIAS BIOMÉDICAS}

Cidade Universitária "Armando de Salles Oliveira"

Av. Prof. Lineu Prestes, 2415 - cep. 05508-000 Săo Paulo, SP - Brasil

Telefone :(55) (11) 3091.7733 telefax : (55) (11) 3091-8405

e-mail: cep@ icb.usp.br

São Paulo, 26 de novembro de 2010.

\section{PARECER 978/CEP}

A Comissão de Ética em Pesquisas com Seres Humanos do ICB, em 25.11.2010, APROvOU o projeto intitulado: “Implantação da técnica de PCR em tempo real para diagnóstico laboratorial das infecções virais do sistema nervoso central no Hospital Universitário da USP" sob responsabilidade de execução dos autores Profa. Dra. Charlotte Marianna Hársi e a aluna Rafaella Almeida Lima NunES

Cabe aos pesquisadores executantes elaborar e apresentar a este Comitê, relatórios anuais (parciais ou final), de acordo com a resolução 196/06 do Conselho Nacional da Saúde, item IX. 2 letra c.

O primeiro relatório deverá ser encaminhado à Secretaria deste CEP em

25.11.2011.

Atenciosamente

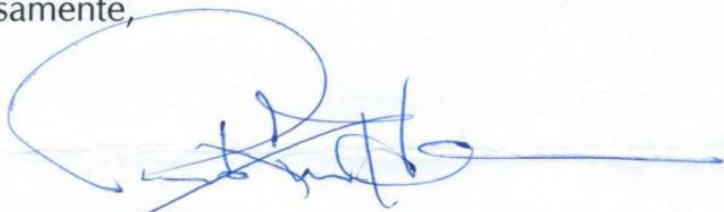

Prof. Dr. Paolo M. A. Zanotto

Coordenador da Comissão de Ética em

Pesquisas com Seres Humanos - ICB/USP 
$I l^{m o(a)} \cdot S^{r(a)}$

Profa. Dra. Marina Baquerizo Martinez

Serviço de Laboratório Clínico do Hospital Universitário

UNIVERSIDADE DE SÃO PAULO

REFERENTE: Subprojeto de Pesquisa "Implantação da técnica de PCR em tempo real para diagnóstico laboratorial complementar de infecções virais do sistema nervoso central do Hospital Universitário da USP" - Orientadora: Dra. Charlotte Marianna Hársi Mestranda: Rafaella Almeida Lima Nunes - Registro CEP-HU/USP: 902/09B - SISNEP CAAE: 0022.0.198.000-11.

Prezado(a) Senhor(a)

O Comitê de Ética em Pesquisa do Hospital Universitário da Universidade de São Paulo, em reunião ordinária realizada no dia 16 de dezembro de 2011, analisou o Projeto de Pesquisa acima citado, considerando-o como APROVADO.

Lembramos que cabe ao pesquisador elaborar e apresentar a este Comitê, relatórios anuais (parciais ou final, em função da duração da pesquisa), de acordo com a Resolução no 196/96 do Conselho Nacional de Saúde, inciso IX.2, letra "c".

O primeiro relatório está previsto para 16 de dezembro de 2012.

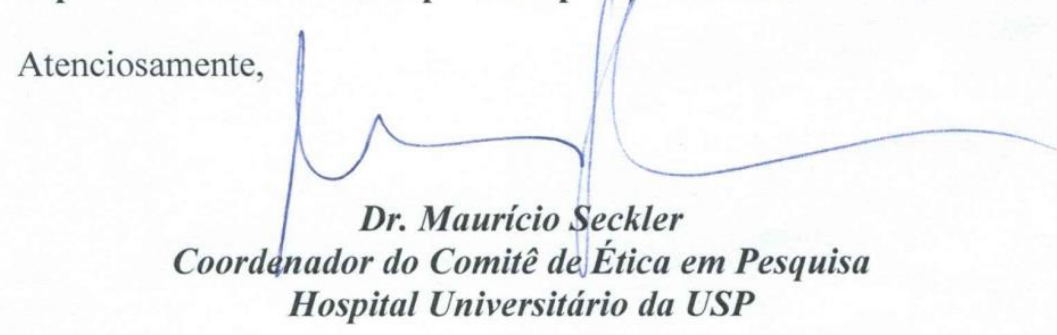

COMITE DE ÉTICA EM PESQUISA DO HOSPITAL UNIVERSITÁRIO DA USP Avenida Professor Lineu Prestes, 2565 - Cidade Universitária - 05508-000 São Paulo - SP Tels.: (11) 3091-9457 - Fax: (11) 3091-9479 - E-mail: cep $a$ hu.usp.br 
A Deus, meu refúgio, minha vitória, Deus do impossível! A minha mãe Águila, meu exemplo, minha vida, razão de eu ter chegado até aqui. Ao meu anjo Telmo, meu sustento, minha força, meu amor. Que nunca me deixou desistir. Sem você este trabalho definitivamente não teria sido concluído. Não tenho palavras... A minha avó Maria, que sempre acreditou em mim, e tenho certeza, está muito orgulhosa. A minha família, que sempre me apoiou. 


\section{AGRADECIMENTOS ESPECIAIS}

\section{A Deus,}

Que cuida de mim desde o meu primeiro suspiro de vida, que nunca falhou, e que me ensinou a agradecer pelas coisas ainda não vistas, e que pela fé, sempre se tornaram reais.

\section{À Profa. Dra. Charlotte Marianna Hársi,}

Por ter aberto as portas para a realização de um sonho, pelo apoio durante todos esses anos, e principalmente pelo incentivo nesta fase final.

Às amigas Juliana e Joselma,

Pelo acolhimento com carinho desde o primeiro dia, por terem me ensinado, direcionado e incentivado, no trabalho e na vida, e por me fazerem rir muito...não tenho palavras para agradecer a vocês! Podem contar comigo para o que for preciso!

Às amigas Telma, Patrícia e Bete,

Que com sua doçura tornaram meus dias mais felizes, mais leves, mais esperançosos. E por fazerem brotar um sorriso no meu rosto quando isso parecia impossível...Isso é o que realmente vale à pena não é?!! Muito obrigada por tudo!!!

À Dra. Marina Baquerizo Martinez e a toda a equipe do HU-USP,

Pela colaboração neste trabalho, orientando, cedendo amostras clínicas, material e espaço para a realização desta pesquisa, sempre com muita simpatia e disponibilidade.

À Profa. Dra. Dolores U. Mehnert,

Minha segunda orientadora, que sempre me tratou como uma de suas alunas. Agradeço também pelo uso dos equipamentos de seu laboratório.

\section{Ao Carlos,}

Grande amigo, sempre disposto a ajudar no que fosse preciso...mineiro de Juiz de Fora como eu, me acolheu como a uma filha. Grande exemplo de como enfrentar as grandes adversidades da vida sem perder a força! 
À amiga Laura,

Pela ajuda em muitos momentos, pelas conversas e pelas dicas veterinárias...rsrsrs!

À amiga Karina,

Pelo apoio científico e principalmente pelos conselhos e apoio emocional.

\section{À Paty Moura,}

Pela ajuda, incentivo, e muitas risadas!!!

À Profa. Dra. Marílis V. Marques,

Pela orientação no inicio do mestrado.

Aos meus irmãos,

Que oraram por mim e me ajudaram a compreender o real sentido da fé.

Aos meus sogros,

Por todo o apoio de sempre, e por me terem como a uma filha.

À minha família, pai, irmãos e cunhados,

Por torcerem sempre pelo meu sucesso.

Ao Neném,

Que com toda a sua inocência, amor e lealdade compartilhou comigo os momentos mais felizes e os mais difíceis, como se fosse um ser humano.

\section{Ao $\mathrm{CNPq}$,}

Pela bolsa de mestrado concedida durantes este trabalho.

A todos os meus verdadeiros amigos,

Sintam-se imensamente agradecidos pelo apoio nos meus momentos mais difíceis. Sem vocês eu não teria vencido! 


\section{AGRADECIMENTOS}

À Dra. Veridiana Munford, pelas conversas, conselhos e palavras de incentivo.

Ao JR, único homem em meio a tantas mulheres enlouquecidas, pela ajuda sempre que necessário e pela torcida.

À Luana, por compartilhar os apertos da vida acadêmica.

Ao Prof. Dr. Enrique Boccardo, pelos valiosos conselhos e ensinamentos.

Aos alunos do Laboratório de Oncovirologia, pela amizade, conversas e pelo café de sempre!

À Gisele, secretária do curso de pós-graduação pelas orientações, paciência e atenção.

Ao Prof. Dr. Paolo Zanotto, pela utilização dos equipamentos de seu laboratório.

Aos amigos Vitor e Dani, pela ajuda, conversas e risadas.

Aos funcionários do SAT, sem os quais nenhuma pesquisa seria possível.

Aos funcionários da biblioteca, pela ajuda e paciência nos momentos finais de elaboração da dissertação.

Ao pessoal da limpeza, que com um sorriso e um bom dia no início da manhã, fizeram meus dias melhores. 
"Pois será como a árvore plantada junto a ribeiros de águas, a qual dá seu fruto na estação própria, $e$ cujas folhas não caem, e tudo quanto fizer prosperará." Salmos 1:3 


\section{RESUMO}

NUNES, R. A. L. Aplicação de técnicas moleculares no diagnóstico laboratorial complementar das infecções virais do sistema nervoso central no Hospital Universitário da USP. 2013. 118 f. Dissertação (Mestrado em Microbiologia) - Instituto de Ciências Biomédicas, Universidade de São Paulo, São Paulo, 2013.

Enterovírus (HEV), herpesvírus 1 e 2 (HHV-1 e HHV-2) e adenovírus (HAdV) são importantes agentes causadores de infecção do SNC. Neste trabalho, técnicas moleculares foram aplicadas para a detecção destes vírus. Amostras de líquor foram colhidas de pacientes com suspeita de infecção do SNC atendidos no Hospital Universitário da USP, entre agosto e novembro/2010 e entre fevereiro/2012 e janeiro/2013. O material genético viral foi extraído através dos métodos Qiaamp DNA Blood (Qiagen ${ }^{\circledR}$ ) e MagMAX ${ }^{T M}$ Viral RNA Isolation (Ambiom), e após comparação, o segundo método mostrou-se mais adequado à aplicação na rotina clínica. Através da reação de Nested-PCR, os HEV foram detectados em 9,8\% das amostras, os HAdV em 2,5\% e HHV-1 e 2 em 1,1\%. Foram observados três casos de coinfecção: 2 entre HEV e HHV, e 1 entre HEV e HAdV. Todas as faixas etárias foram atingidas, com predomínio nos pacientes com menos de 20 anos de idade. Apenas as infecções por HEV apresentaram sazonalidade bem definida, ocorrendo mais frequentemente nos meses mais quentes do ano. Os diagnósticos de entrada anotados foram variados, mas a maior frequência de amostras positivas foi observada naqueles pacientes cujo diagnóstico já indicava meningite ou sintomas relacionados a esta patologia. A análise quimiocitológica do líquor permitiu observar que os vírus foram detectados com maior frequência em amostras com celularidade elevada, embora também tenham sido encontrados em amostras com número normal de células. As alterações nos níveis proteicos do líquor não apresentaram correlação com a presença de vírus. A concentração de glicose apresentou, em geral, níveis dentro da normalidade, embora sua redução tenha sido observada em alguns casos nos quais foram detectados HHV-1 e 2. A análise quimiocitológica do líquor mostrou-se importante no direcionamento da conduta clínica, mas a detecção e identificação do vírus é fundamental para a conclusão do diagnóstico. Neste contexto, torna-se importante a aplicação de técnicas moleculares, que permitam a efetiva detecção viral. A reação de PCR em tempo real, cuja padronização foi iniciada neste trabalho, consiste em importante ferramenta para a utilização futura no diagnóstico complementar das infecções virais do SNC, e maiores esforços serão dispensados para a definitiva padronização e aplicação desta técnica na rotina clínica.

Palavras-chave: Meningites. Meningoencefalites. Reação em cadeia da polimerase. Adenovírus humanos. Enterovírus humanos. Herpesvírus humanos. 


\begin{abstract}
NUNES, R. A. L. Molecular techniques application for the complementary laboratory diagnosis of viral infections of the central nervous system at the University Hospital of USP. 2013. 118 p. Masters thesis (Microbiology) - Instituto de Ciências Biomédicas, Universidade de São Paulo, São Paulo, 2013.

Enteroviruses (HEV), herpesviruses 1 and 2 (HHV-1 and HHV-2) and adenoviruses (HAdV) are important causative agents of infections of the CNS. In this study, molecular techniques were applied to the detection of these viruses. CSF samples were collected from patients with suspected CNS infection, treated at the University Hospital of USP, between August and November, 2010, and between February 2012 and January 2013. The viral genetic materials were extracted by QIAamp DNA Blood kit (Qiagen ${ }^{\circledR}$ ) and MagMAX ${ }^{\mathrm{TM}}$ Viral RNA Isolation (Ambiom) methods, and after comparison, the second one showed to be more suitable for the application in clinical diagnosis. By the Nested-PCR reaction, HEV were detected in $9.8 \%$ of the samples, $\mathrm{HAdV}$ in $2.5 \%$ and $\mathrm{HHV}-1$ and 2 in $1.1 \%$. There were 3 cases of coinfection: 2 with HEV and HHV and other with HEV and HAdV. All age groups were affected, with higher prevalence in patients under the age of 20 years. Only HEV infections showed defined seasonality, occurring more frequently in the warmer months of the year. Several different admission diagnosis were reported, but the highest frequency of positive samples was observed on those patients whose diagnostic already indicated meningitis or related symptoms. The chemocytologic analysis of CSF indicated that viruses were detected more frequently in samples with high cellularity, although they have also been detected in samples with normal number of cells. Changes in the CSF protein levels did not correlate with the presence of viruses. The glucose concentration was, generally, within normal levels, although its reduction has been observed in some cases with HHV-1 and 2. The chemocytologic analysis CSF proved to be important in directing the clinical conduct, but the detection and identification of viruses is essential for the diagnosis. In this context, it is important to apply molecular techniques for effective viral detection. The real time PCR, which standardization was initiated in this work, will be an important tool for the viral diagnosis. Efforts will be done for the final standardization and application of this technique in the complementary laboratory diagnosis of viral infections of the CNS.
\end{abstract}

Keywords: Meningitis. Meningoencephalitis. Polymerase chain reaction. Human adenovirus. Human enterovirus. Human herpesvirus. 


\section{LISTA DE FIGURAS}

Figura 1- Incidência (por 100.000 habitantes) das meningites segundo etiologias no Estado de São Paulo, de 1998 a 2011.

Figura 2 - Distribuição percentual dos casos de meningite segundo etiologias no Estado de São Paulo, de 1998 a 2012.

Figura 3 - Frequência das meningites segundo etiologias entre 2007 e 2012 no Brasil

Figura 4 - Representação esquemática e fotomicrografia eletrônica da partícula de poliovírus.

Figura 5 - Representação esquemática e fotomicrografia eletrônica da partícula de adenovírus.

Figura 6 - Representação esquemática e fotomicrografia eletrônica da partícula de herpesvírus.

Figura 7 - Fotomicrografia eletrônica da partícula de herpesvírus: estrutura viral. .38

Figura 8 - Esquema das reações envolvendo os sistemas Syber ${ }^{\circledR}$ Green e $\operatorname{TaqMan}^{\circledR}$..

Figura 9 - Aspecto de células HEK 293 em cultura antes e após a inoculação de HAdV-2 padrão.

Figura 10 - Aspecto de células GMK em cultura antes e após a inoculação com Coxsackievírus B5 padrão.

Figura 11 - Aspecto de células VERO em cultura antes e após inoculação com HHV-1 padrão.

Figura 12 - Perfil eletroforético dos produtos amplificados de HAdV, HEV e HHV-1/HHV-2 após a reação de PCR.

Figura 13 - Perfil eletroforético dos produtos amplificados de HAdV, HEV e HHV-1 após a reação de Nested-PCR.

Figura 14 - Perfil eletroforético das amostras de LCR nas quais foram detectados HAdV após reação de Nested $-\mathrm{PCR}$.

Figura 15 - Perfil eletroforético das amostras de LCR nas quais foram detectados HEV após reação de Nested-PCR.

Figura 16 - Perfil eletroforético das amostras de LCR nas quais foram detectados HHV1/HHV-2 após reação de Nested - PCR

Figura 17 - Frequência relativa de HAdV, HEV e HHV (HHV-1 e HHV-2) detectados em relação ao total de amostras de LCR analisadas. 
Figura 18 - Perfil eletroforético dos produtos amplificados das diluições do DNA extraído de HAdV-2 após a reação de Nested-PCR.

Figura 19 - Curva de amplificação das diluições do DNA de HAdV-2 e das amostras de LCR HU 23/10 e 133/12 após reação de PCR em tempo real

Figura 20 - Curva padrão correspondente às diluições do DNA de HAdV-2 e amostras de LCR HU 23/10 e 133/12 após reação de PCR em tempo real.

Figura 21 - Perfil dos produtos amplificados das diluições do cDNA proveniente de enterovírus padrão (Coxsackievírus B5) após a reação de Nested-PCR

Figura 22 - Curva de amplificação das diluições do cDNA de enterovírus (Coxsackievírus B5) e amostra de LCR HU 02/10 obtida após reação de PCR em tempo

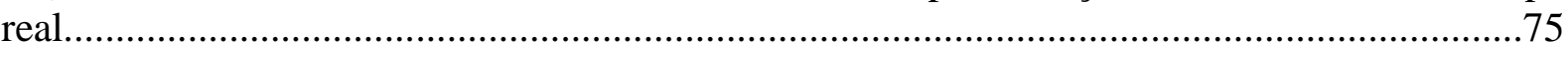

Figura 23 - Curva padrão das diluições do cDNA de enterovírus (Coxsackievírus B5) e amostra de LCR HU 02/10 obtida após reação de PCR em tempo real.

Figura 24 - Frequência mensal das amostras positivas e negativas colhidas entre fevereiro/2012 e janeiro/2013 após reação de Nested-PCR para a detecção de HAdV, HEV e HHV-1/HHV-2.

Figura 25 - Frequência de infecções do SNC por HAdV, HEV e HHV-1/HHV-2. Distribuição por faixa-etária. 


\section{LISTA DE QUADROS}

Quadro 1 - Etiologia e epidemiologia de alguns dos principais vírus associados a quadros de infecção do SNC

Quadro 2 - Características do líquor e alterações apresentadas em casos de infecção.

Quadro 3 - Disposição dos reagentes e amostras na placa para extração dos ácidos nucleicosMagMAX ${ }^{T M}$ Viral RNA Isolation (Ambiom).

Quadro 4 - Esquema de tabulação dos resultados para a comparação de sensibilidade, especificidade, VPP e VPN entre os métodos utilizados para a extração de ácidos nucleicos.58

Quadro 5 - Sequências dos oligonucleotídeos utilizados nas reações de PCR e Nested-PCR para a detecção de HAdV, HEV e HHV-1 e 2

Quadro 6 - Temperaturas de anelamento dos oligonucleotídeos utilizados nas reações de PCR e Nested-PCR

Quadro 7 - Conjuntos de sondas e primers utilizados para a detecção de adenovírus e enterovírus através da reação de PCR em tempo real. 


\section{LISTA DE TABELAS}

Tabela 1 - Critérios de confirmação das meningites assépticas no Brasil em 2011 e 2012.....48

Tabela 2 - Resultados obtidos após extração dos ácidos nucleicos presentes nas amostras de líquor, seguida das reações de PCR e Nested-PCR para a detecção de HAdV, HEV e HHV1/HHV-2. Comparação dos métodos de extração

Tabela 3 - Relação entre o agente viral detectado e a faixa-etária dos pacientes .79

Tabela 4 - Relação entre o quadro clínico dos pacientes e a efetiva detecção de vírus nas amostras clínicas.

Tabela 5 - Agentes virais detectados nas amostras clínicas de acordo com o quadro clínico.

Tabela 6 - Distribuição das amostras de LCR de acordo com a celularidade observada após análise quimiocitológica.

Tabela 7 - Correlação entre os vírus detectados e a celularidade das amostras de LCR.

Tabela 8 - Distribuição das amostras positivas e com celularidade aumentada em relação ao predomínio de neutrófilos, linfócitos ou monócitos.

Tabela 9 - Níveis de proteínas das amostras de LCR analisadas. .85

Tabela 10 - Níveis de glicose das amostras de LCR analisadas .86 


\section{LISTA DE ABREVIATURAS E SIGLAS}

CVE - Centro de Vigilância epidemiológica

DATASUS - Banco de Dados do Sistema Único de Saúde

HAdV - Adenovírus humanos

HEV - Enterovírus Humanos

HHV-1 - Herpesvírus Humanos do tipo 1

HHV-2 - Herpesvírus Humanos do tipo 2

HIV - Vírus da Imunodeficiência Humana

HU - Hospital universitário

USP - Universidade de São Paulo

ICB - Instituto de Ciências Biomédicas

ICTV - International Committee on Taxonomy of Viruses

SNC - Sistema Nervoso Central

LCR - Líquido cefalorraquidiano, líquor

OMS - Organização Mundial de Saúde

PCR - Polymerase chain reaction

DNA - Ácido desoxirribonucleico

ATCC - American Type Culture Collection

$\mathrm{CO}_{2}$ - Dióxido de carbono

cDNA - DNA complementar

DEPC - Dietilpirocarbonato

dNTP - Desoxirribonucleotídeo fosfatado

DTT - Dithiothreitol 
ECP - Efeito citopático

EDTA - Ácido etilenodiaminotetracético

EMEM - Meio mínimo essencial Eagle

PBS - Solução salino fosfatada

TAE - Tampão contendo tris-acetato, ácido acético e EDTA

SFB - Soro fetal bovino

$\mathrm{pH}$ - Potencial hidrogeniônico

U - Unidade

dL - Decilitro

mg - Miligrama

mm³ - Milímetro cúbico

$\mu \mathrm{L}$ - Microlitro

$\mathrm{mM}$ - Milimolar

pmoles - Picomoles

$\mathrm{pb}$ - Pares de base 


\section{SUMÁRIO}

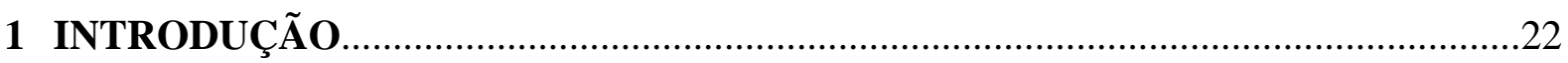

1.1 Breve apresentação e histórico das infecções do sistema nervoso central.................22

1.2 Epidemiologia das infecções virais do sistema nervoso central...............................23

1.3 Etiologia das infecções virais do sistema nervoso central ....................................28

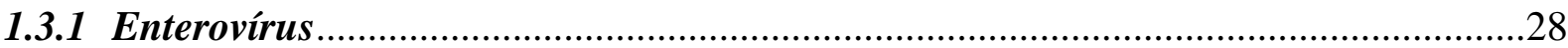

1.3.1.1 Características da partícula viral e taxonomia .......................................................29

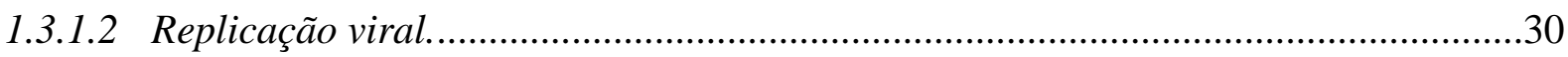

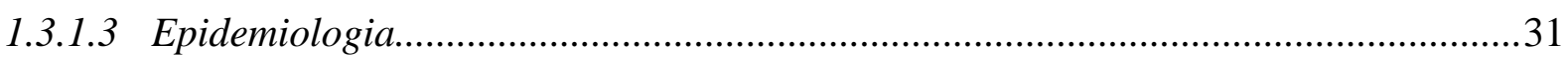

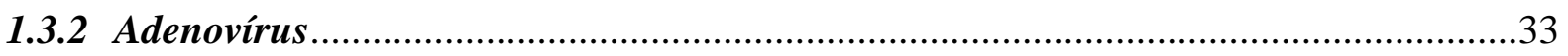

1.3.2.1 Características da partícula viral e taxonomia.........................................................33

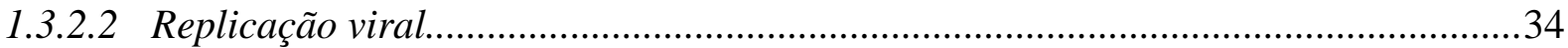

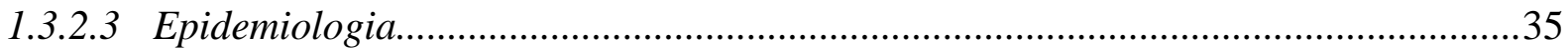

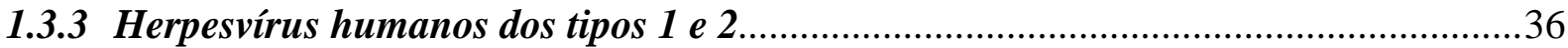

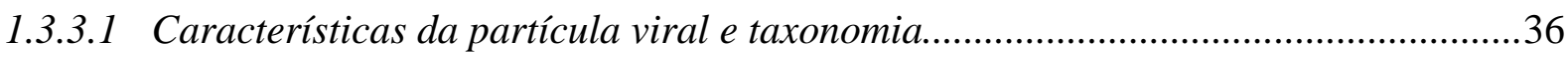

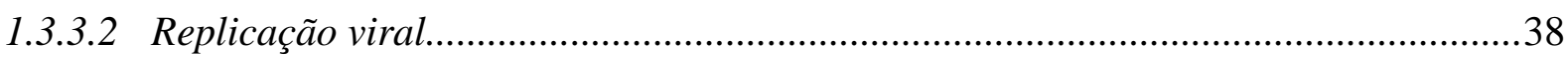

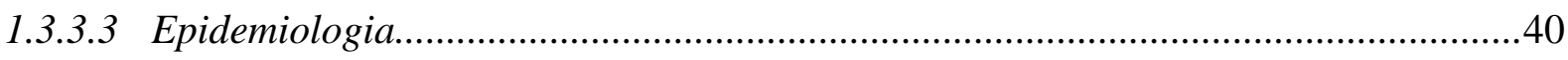

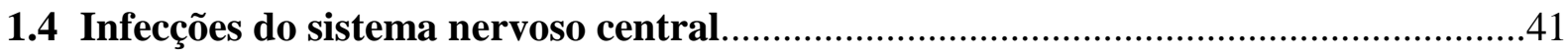

1.5 Patogênese e disseminação dos vírus neurotrópicos.................................................42

1.6 Características das infecções do sistema nervoso central..........................................44

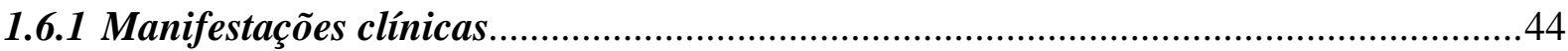

1.6.2 Características do líquor e alterações provocadas pelas infecções do sistema nervoso central.

1.7 Diagnóstico das infecções virais do sistema nervoso central....................................48

1.7.1 Diagnóstico molecular das infecções do sistema nervoso central..............................49

2 OBJETIVOS

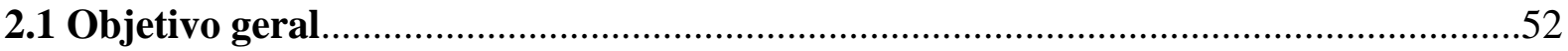

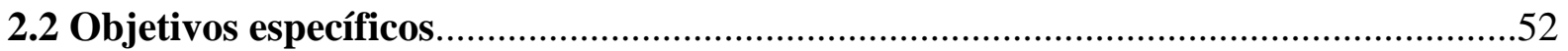

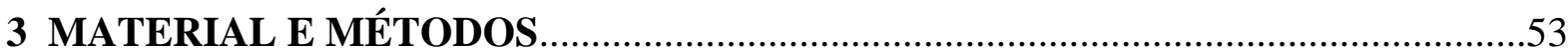

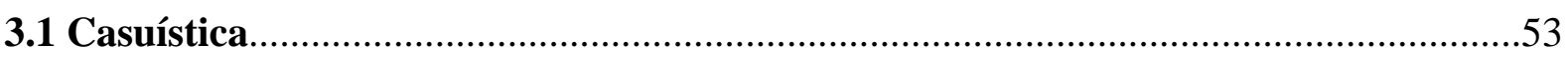

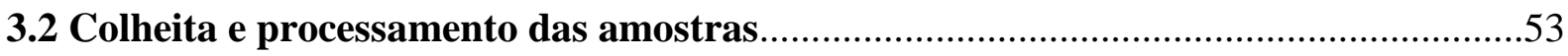

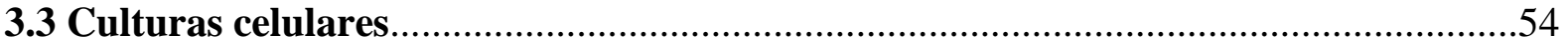

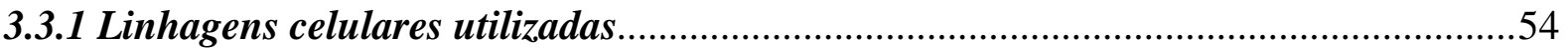




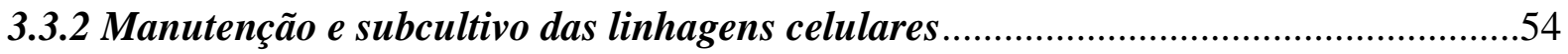

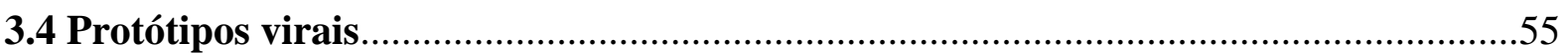

3.4.1 Cultivo dos protótipos de adenovírus, enterovírus e herpesvírus.................................55

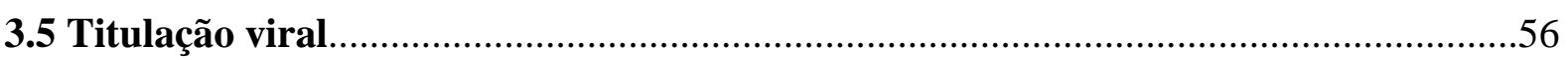

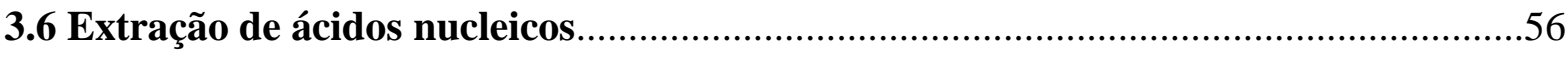

3.7 Comparação dos métodos de extração dos ácidos nucleicos......................................58

3.8 Transcrição reversa do genoma dos enterovírus......................................................60

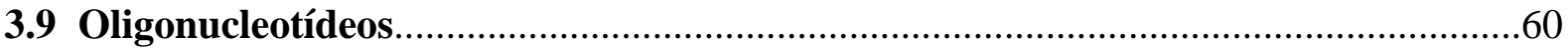

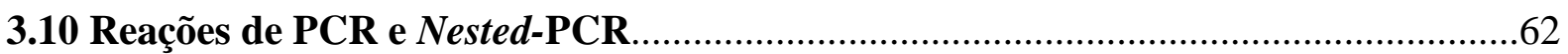

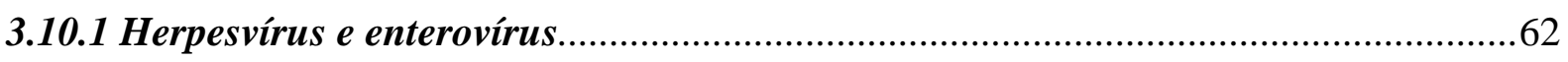

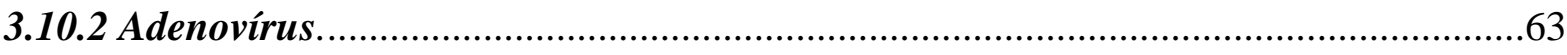

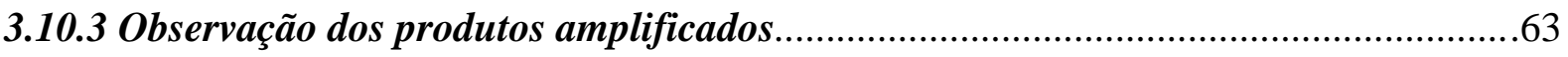

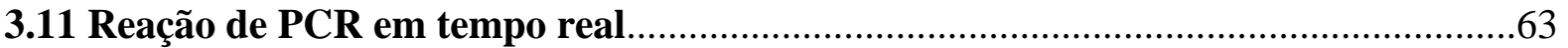

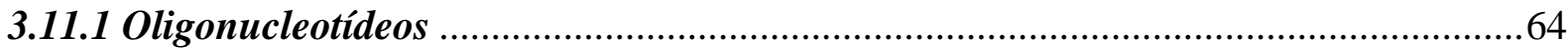

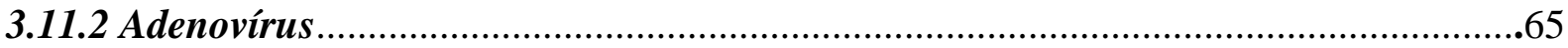

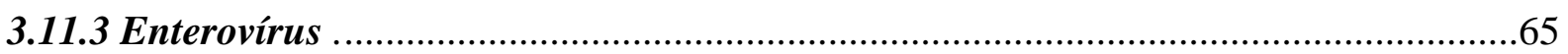

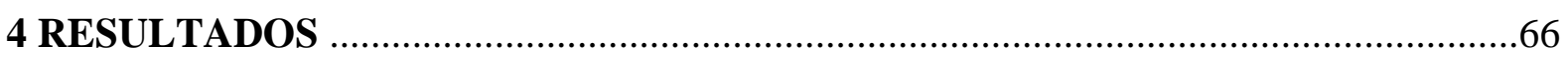

4.1 Cultivo dos protótipos de adenovírus, enterovírus e herpesvírus..............................66

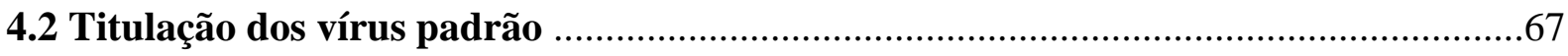

4.3 Avaliação dos protocolos utilizados para a extração do DNA e RNA viral.................67

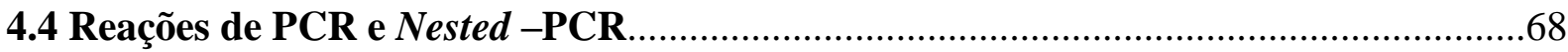

4.5 Detecção de HAdV, HEV, HHV-1 e HHV-2 nas amostras de LCR através da técnica

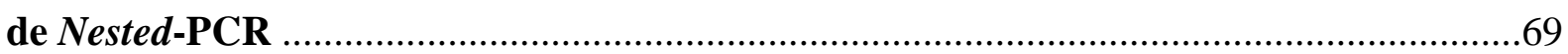

4.6 Padronização da reação de PCR em tempo real...........................................................72

4.6.1 Reação de PCR em tempo real para a detecção de adenovírus ..................................72

4.6.2 Reação de PCR em tempo real para a detecção de enterovírus .................................74

4.6.3 Correlação entre o título viral dos $\mathrm{HAdV}$ e HEV e o limiar de detecção das reações

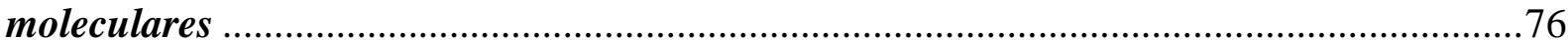

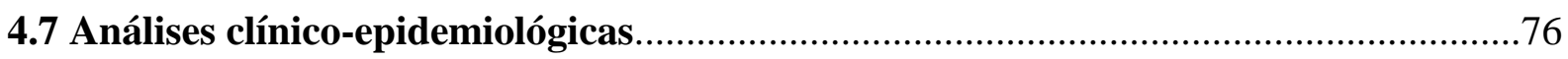

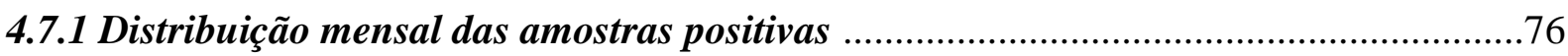

4.7.2 Relação entre a positividade das amostras de LCR e a faixa-etária dos pacientes......78

4.7.3 Relação entre o quadro clínico dos pacientes e a positividade das amostras...............79

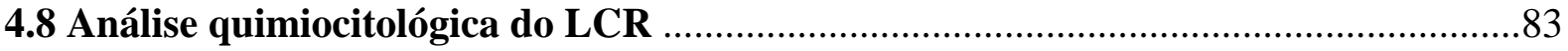

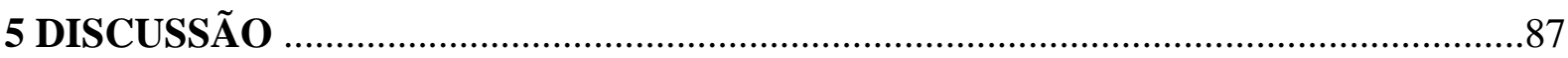


6 CONCLUSÕES

.107

REFERÊNCIAS 


\section{INTRODUÇÃO}

\subsection{Breve apresentação e histórico das infecções do sistema nervoso central}

A meningite é uma doença caracterizada pela inflamação das meninges, membranas que envolvem o encéfalo e a medula espinhal. Os sintomas incluem febre, mal estar, cefaleia intensa, vômitos, letargia, mialgia, irritabilidade e sinais de irritação meníngea (rigidez de nuca, e sinais de Kernig, Brudzinski e Lasègue) (ANDERSON, 1993).

Outro importante processo inflamatório que acomete o sistema nervoso central (SNC) é a encefalite, que pode ter origem infecciosa ou resultar de processos autoimunes, toxinas, drogas e outras condições (SOMAND; MEURER, 2009).

Os primeiros relatos referentes às infecções do SNC são bastante antigos. Desde os tempos primitivos, foram reconhecidas determinadas condições caracterizadas por febre, dor de cabeça, vômitos, distúrbios mentais e de consciência, que resultavam na morte dos pacientes (WALKER; LAWS; UDVARHELYI, 1998).

Alguns autores sugerem que médicos importantes da história, como Hipócrates, já faziam referência às meningites em seus manuscritos (ATTIA et al., 1999). Pertence a Thomas Willis, em meados do século XVII, a primeira descrição detalhada da meningite em sua forma epidêmica, em "A description of an epidemical fever". Apenas em 1887, dois séculos mais tarde, foi isolado pelo patologista e bacteriologista austríaco Anton Weichselbaum o primeiro agente etiológico relacionado a esta enfermidade, a Neisseria meningitidis. Embora alguns autores tenham estudado o líquor e tentado descrever as alterações associadas às infecções do SNC, apenas em 1981 o doutor Heinrich Irenaeus Quincke introduziu a punção lombar com fins diagnósticos e terapêuticos (CARVALHO, 1994; SCHREIBER; MATHYS, 1991; WALKER; LAWS; UDVARHELYI, 1998). Desde então, os demais agentes etiológicos bacterianos foram sendo gradativamente identificados, porém ainda não havia sido mencionada a possível etiologia viral das infecções do SNC.

O primeiro relato de epidemia de meningite refere-se ao ocorrido em $1805 \mathrm{em}$ Genebra. A partir de então, novos casos foram observados na Inglaterra, além da ocorrência de epidemias na Europa e América do Norte durante o século XIX. O continente africano tem sido alvo de surtos e epidemias que preocupam as autoridades de saúde até os dias de hoje, principalmente associados à doença de etiologia bacteriana (GREENWOOD, 2006).

Em 1842 foi realizada a primeira descrição de uma epidemia de meningite no Brasil, ocorrida no Rio de Janeiro, com registro de aproximadamente 20 casos. Em fevereiro de 
1906, surgiram os primeiros casos em São Paulo, entre imigrantes europeus. Nesta época, o tratamento era exclusivamente paliativo e não havia nenhuma medida específica de prevenção e controle (CARVALHANAS; BRANDILEONI; ZANELLA, 2005).

Atualmente, mesmo com a evolução das possibilidades preventivas e terapêuticas, a ocorrência e a gravidade destas infecções ainda constituem um importante problema de Saúde Pública, sobretudo, mas não exclusivamente, envolvendo as populações mais carentes.

As meningites virais são, também, denominadas meningites assépticas, embora estes termos não sejam exatamente sinônimos. Em 1925, Wallgren usou o termo "meningite asséptica" para designar as infecções de evolução clínica mais branda, incluindo todas as meningites que apresentavam líquor claro, em que nenhuma causa fosse detectada pelas técnicas rotineiras de laboratório (CAVALCANTI, 1994). Christie (1969) observou que uma característica marcante das infecções de etiologia viral do SNC era o predomínio de linfócitos no líquor, e sugeriu o termo "meningite linfocitária" para denominar tais infecções.

Os vírus são responsáveis pela grande maioria dos casos de infecção aguda do SNC. Apesar das baixas taxas de mortalidade a eles associadas, podem ser observadas elevadas taxas de morbidade, e dependendo do agente viral envolvido, quadros graves de alteração do SNC, com alto risco de ocorrência de sequelas e ocasional morte do paciente, o que contraria a ideia de que tais infecções sempre estão associadas a um curso benigno (BEDOYA; LEITE, 1998).

\subsection{Epidemiologia das infecções virais do sistema nervoso central}

As infecções do SNC acometem, anualmente, milhões de pessoas em todo o mundo, e estão relacionadas a elevadas taxas de morbidade e mortalidade (ORGANIZAÇÃO MUNDIAL DE SAÚDE - OMS, 2012).

As meningites apresentam distribuição mundial, e fatores como clima, presença de aglomerados populacionais, condições e infraestrutura de saúde e virulência dos agentes infecciosos podem interferir em sua expressão epidemiológica.

Merecem destaque, em Saúde Pública, as meningites bacterianas e virais, que são doenças de notificação compulsória no Brasil, devido à ampla ocorrência e ao alto potencial de produzirem surtos. Quantitativamente, os vírus são os principais agentes etiológicos envolvidos, e embora, em geral, não causem infecções tão severas quanto às de etiologia bacteriana, destacam-se pela magnitude de sua ocorrência e relevância social (ROOS, 2005). Cabe ressaltar, porém, que quando associada a determinados agentes como os herpesvírus, 
ocasionalmente causadores de quadros de encefalites, a gravidade da doença pode ser bem maior, com altas taxas de mortalidade, o que exige diagnóstico e tratamento imediato.

Nas figuras 1 e 2 são expressas a incidência e a distribuição percentual dos casos de meningite no Estado de São Paulo de acordo com sua etiologia.

Figura 1- Incidência (por 100.000 habitantes) das meningites segundo etiologias no Estado de São Paulo, de 1998 a 2011.

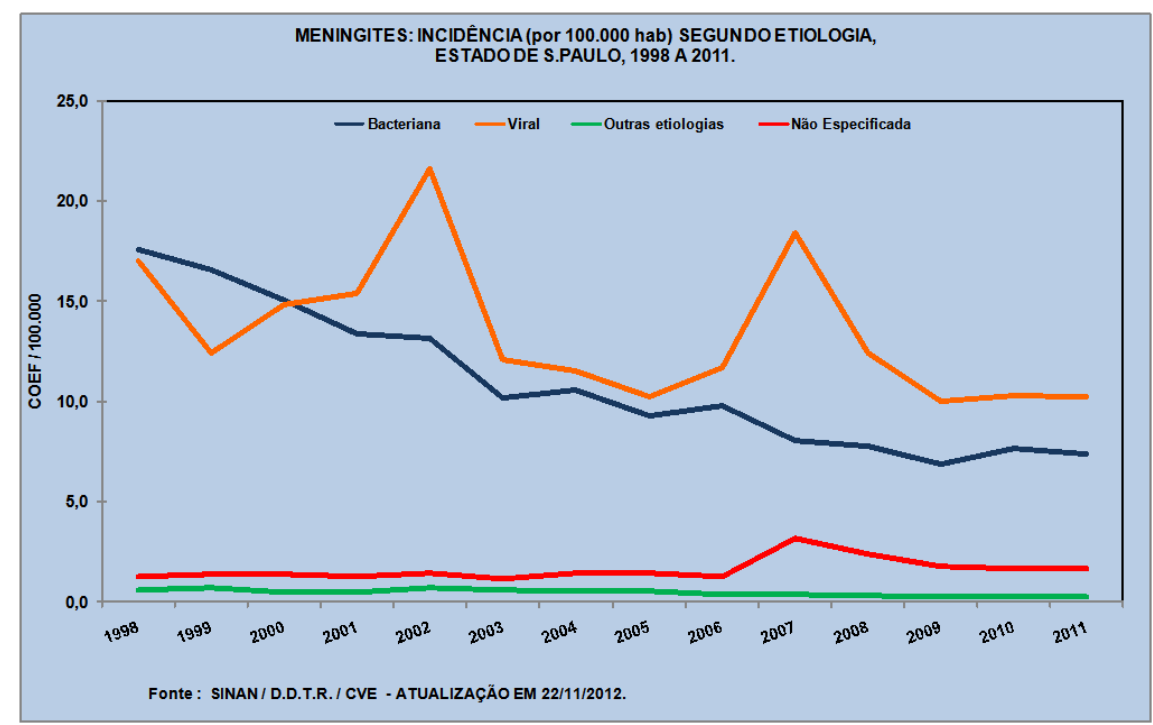

Fonte: Centro de Vigilância Epidemiológica de São Paulo - CVE, 2013.

$\mathrm{Na}$ figura acima pode ser observada a queda progressiva da incidência das meningites bacterianas entre os anos de 1998 e 2011. Semelhante observação não pode ser realizada no que tange às infecções virais, cujo curso foi marcado por picos de incidência da doença, possivelmente associados a surtos.

De acordo com a figura 2, pode ser observado que entre 1998 e 2012, cerca de 50\% das infecções do SNC notificadas no Estado de São Paulo apresentavam etiologia viral. No entanto, embora as infecções virais sejam mais frequentes, o número de óbitos a elas relacionado é muito inferior ao observado nas infecções de etiologia bacteriana. No Estado de São Paulo, desde o início de 2013 até o presente momento, 123 casos de meningite viral foram notificados, e nenhum óbito foi associado a tais ocorrências (CVE-SP, 2013). 
Figura 2 - Distribuição percentual dos casos de meningite segundo etiologias no Estado de São Paulo, de 1998 a 2012.

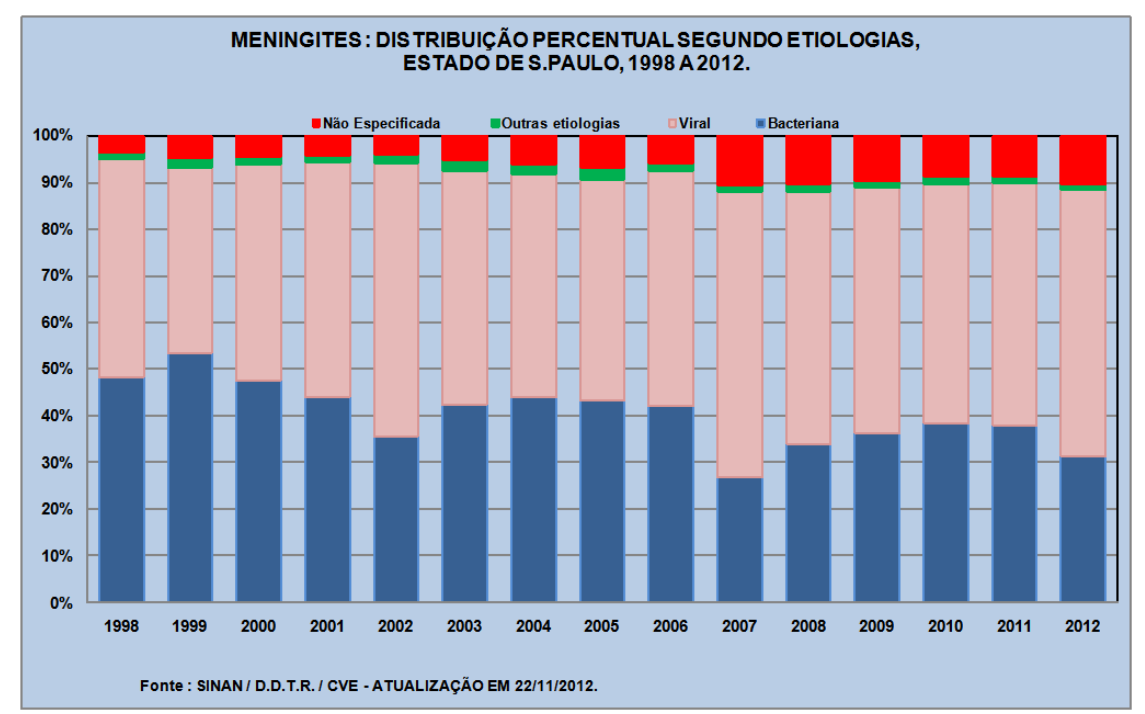

Fonte: CVE-SP, 2013.

No Brasil, de acordo com dados do Departamento de Informática do Sistema Único de Saúde (DATASUS, 2013), entre os anos de 2007 e 2012, 137. 906 casos de meningite foram notificados, dos quais 44,3\% correspondiam a quadros de meningite asséptica. Considerandose apenas a faixa etária abaixo dos 15 anos, foram observados 84.533 casos de meningite, 63,5\% de todas as ocorrências, confirmando a importância destas infecções nesta faixa etária. No ano de 2013, até o presente momento, 866 dos 1.804 casos notificados no país correspondem a quadros de meningite asséptica (DATASUS, 2013).

A figura 3 mostra a frequência das meningites segundo etiologias no Brasil.

Figura 3 - Frequência das meningites segundo etiologias entre 2007 e 2012 no Brasil.

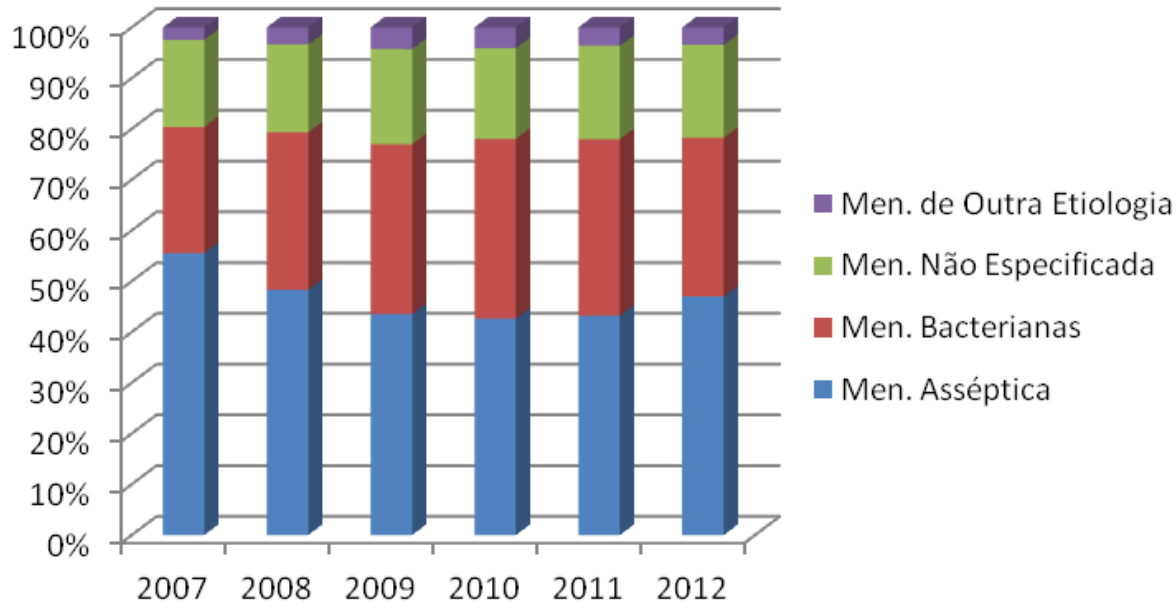

Fonte: DATASUS, 2013. 
Observa-se que, assim como no Estado de São Paulo, as meningites virais são responsáveis por quase metade das ocorrências notificadas no Brasil.

As infecções virais do SNC são consideradas importantes em todo o mundo, e para alguns patógenos envolvidos, a sazonalidade e a distribuição geográfica são bem marcantes. Nestes casos, como ocorre com os enterovírus e arbovírus, o conhecimento da história e trajetória do paciente pode contribuir para direcionar o diagnóstico (ROSS, 2005).

O quadro a seguir mostra alguns dos principais vírus envolvidos em quadros de infecção do SNC e breve epidemiologia (Quadro 1). 
Quadro 1 - Etiologia e epidemiologia de alguns dos principais vírus associados a quadros de infecção do SNC.

\begin{tabular}{|c|c|}
\hline Tipo de Vírus & Epidemiologia \\
\hline Enterovírus & $\begin{array}{l}\text { Maior incidência em crianças, nos períodos de verão e outono } \\
\text { em países de clima temperado, e durante todo o ano em climas } \\
\text { tropicais. Curso geralmente benigno, mas com possíveis } \\
\text { complicações em neonatos e pacientes imunodeprimidos. }\end{array}$ \\
\hline Vírus da caxumba & Atinge com frequência a população não imunizada. \\
\hline West Nile virus & $\begin{array}{l}\text { Infecção transmitida por mosquito (arbovirose). Mais frequente } \\
\text { em países de clima temperado, marcante no final do verão. Fatal } \\
\text { em } 4-13 \% \text { dos casos. }\end{array}$ \\
\hline Japanese encephalitis virus & $\begin{array}{l}\text { Transmitido através da picada de um mosquito, mais frequente } \\
\text { no sudeste da Ásia. Mortalidade entre } 20-30 \% \text { ou lesão } \\
\text { neurológica a longo prazo. }\end{array}$ \\
\hline Tick-borne encephalitis virus & $\begin{array}{l}\text { Presente na Europa e Ásia, comum na primavera e início do } \\
\text { verão. } 1-20 \% \text { dos casos são fatais. }\end{array}$ \\
\hline Vírus da imunodeficiência humana (HIV) & $\begin{array}{l}\text { Presente em } 5-10 \% \text { dos pacientes HIV positivos } \\
\text { soroconvertidos. As complicações são raras em infecções } \\
\text { precoces por HIV. A infecção crônica está relacionada à } \\
\text { demência. }\end{array}$ \\
\hline $\begin{array}{l}\text { Herpesvírus humanos tipos } 1 \text { e } 2 \\
\text { (HHV-1 e HHV-2) }\end{array}$ & $\begin{array}{l}\text { HHV-1 está mais associado a encefalites e HHV-2 a meningites. } \\
\text { Fatais em } 70 \% \text { das encefalites não tratadas, com alto potencial } \\
\text { de deixar sequelas. }\end{array}$ \\
\hline Citomegalovírus (CMV) & Comum em pacientes imunodeprimidos. \\
\hline Vírus da Varicela Zoster (VZV) & $\begin{array}{l}\text { Ocorre como rara complicação da catapora. Podem acompanhar } \\
\text { episódios de zoster em idosos ou encefalite crônica difusa em } \\
\text { imunodeprimidos. }\end{array}$ \\
\hline
\end{tabular}

Fonte: Adaptado de Santos, 2009.

Outros vírus associados a quadros de infecção do SNC que devem ser citados são: vírus Epstein-Barr, adenovírus humanos e outros flavivírus (vírus da dengue, febre amarela, 
Saint Louis) e alfavírus (Eastern Equine Encephalitis, Western Equine Encephalitis e Venezuelan Equine Encephalitis) (MONDINI et al., 2007; SÃO PAULO, 2006).

Uma questão que compromete a obtenção de dados epidemiológicos no que tange às infecções do SNC, principalmente às de etiologia viral, é a subnotificação. A suavidade e brevidade dos sintomas associados a grande parte das infecções virais, principalmente em adultos, não conduz à procura por atendimento médico por parte do paciente, e nos casos nos quais há a procura pelo atendimento de saúde, nem todas as ocorrências são corretamente diagnosticadas e notificadas.

Mesmo sendo os vírus os prováveis responsáveis pela maioria das infecções do SNC, dificilmente o agente causador é identificado. Isso ocorre porque o diagnóstico padrão dessas infecções é baseado no exame clínico-epidemiológico e na análise quimiocitológica, bacteriológica e micológica do líquor. Na grande maioria das vezes, o diagnóstico das meningites virais ocorre por exclusão, e a detecção efetiva dos vírus não é realizada.

\subsection{Etiologia das infecções virais do sistema nervoso central}

\subsubsection{Enterovírus}

A maioria dos sorotipos de enterovírus foi descoberta e descrita entre os anos de 1947 e 1963, como resultado da aplicação de culturas celulares e da utilização de camundongos lactentes, recém-nascidos, no isolamento viral, visando à investigação de casos de paralisia infantil e outras doenças do SNC. Em 1948, durante uma epidemia de poliomielite na cidade de Coxsackie, nos Estados Unidos, foi isolado, pela primeira vez, um coxsakievírus, que se diferenciava claramente dos poliovírus pelo tipo de patogenicidade apresentada. No ano seguinte, foi isolado o primeiro coxsackievírus do grupo $\mathrm{B}$, através da investigação de casos de meningite asséptica. No ano de 1951, a partir das fezes de indivíduos assintomáticos, foi isolado o primeiro echovírus, e estudos posteriores mostraram que estes são responsáveis por uma variedade de doenças em seres humanos (OBERSTE; PALLANSCH, 2003; PALLANSCH; ROOS, 2007).

Os enterovírus estão associados a enfermidades que acomentem todas as faixasetárias, geralmente de gravidade leve a moderada, embora quadros graves possam ser observados em crianças e indivíduos imunocomprometidos. Além disso, este grupo de vírus é a causa mais comum de meningite asséptica, infecção mais frequente do SNC (PALLANSCH; ROOS, 2007). 


\subsubsection{Características da partícula viral e taxonomia}

O gênero Enterovirus pertence à família Picornaviridae. São vírus de RNA de fita simples de polaridade positiva, não envelopados, com 28 a $30 \mathrm{~nm}$ de diâmetro e que apresentam simetria icosaédrica. Em geral, as partículas são resistentes a solventes orgânicos, a desinfetantes utilizados em laboratórios como o etanol 70\% e a condições de baixo pH, além de serem bastante estáveis à temperatura ambiente. Tais propriedades explicam a elevada estabilidade da partícula viral no ambiente, diretamente relacionada à transmissão fecal-oral e à replicação no trato gastrointestinal (PALLANSCH; ROOS, 2007).

O capsídeo dos membros da família Picornaviridae é composto por quatro proteínas estruturais: VP1, VP2, VP3 e VP4, exceto no caso dos Parechovírus. As proteínas VP1, VP2 e VP3 estão expostas parcialmente na superfície do vírion, enquanto a VP4 está voltada para seu interior. A proteína VP1 apresenta os epítopos antigênicos associados à indução da produção de anticorpos neutralizantes (PALLANSCH; ROOS, 2007).

Figura 4 - Representação esquemática e fotomicrografia eletrônica da partícula de poliovírus.

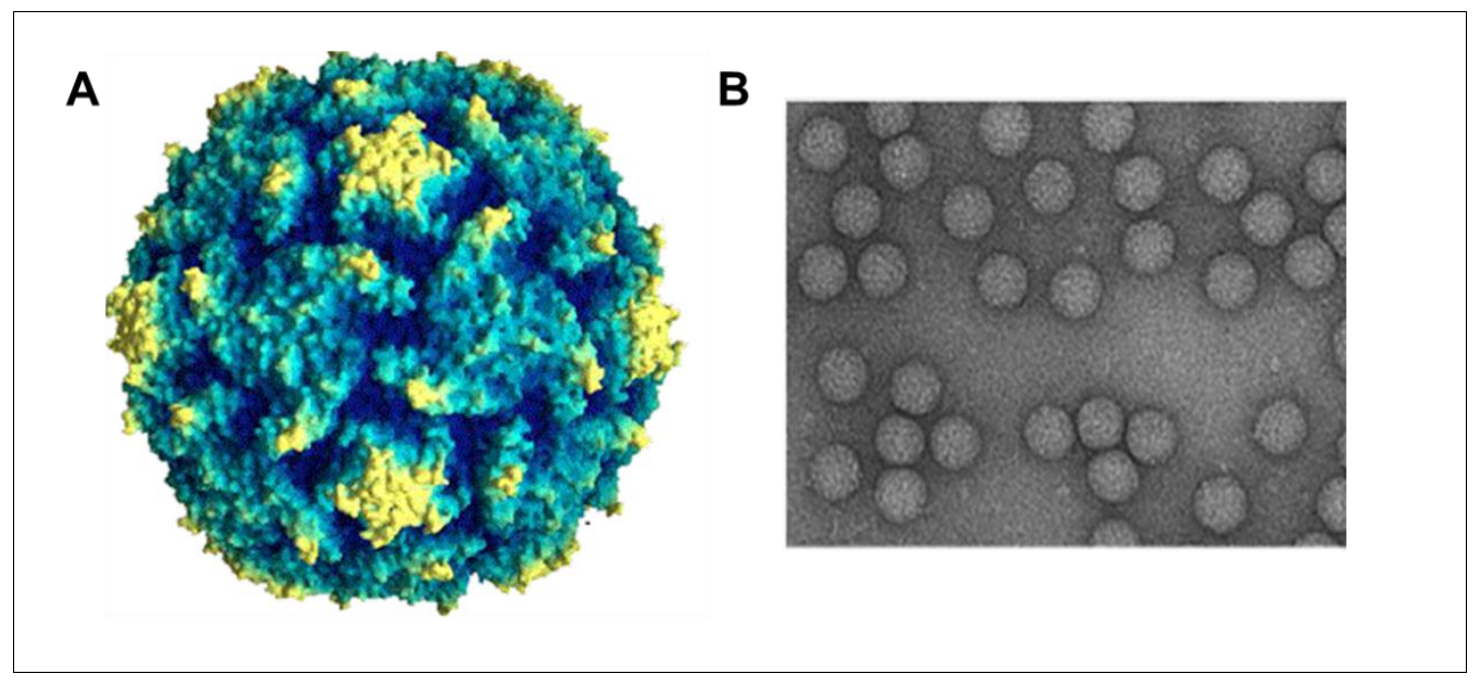

(A): Representação esquemática de uma partícula de poliovírus tipo 1 (renderização de profundidade radial). (B): microscopia eletrônica de partículas de poliovírus em aumento de 270.000x.

Fontes: Hogle et al., 1985; Racaniello, 2007.

O genoma dos membros da família Picornaviridae varia de 7.209 a 8.450 bases. A região 5'NTR (nontranslated region) é a maior do genoma com 624 a 1.199 nucleotídeos, e contém sequências responsáveis pelo controle da replicação e da transcrição. 
Atualmente estão descritas doze espécies dentro do gênero Enterovirus: Enterovirus A a $H$, Enterovirus $J$ e Rhinovirus $A$ a $C$. Dentro das espécies de enterovírus encontramos diferentes sorotipos como poliovírus, echovírus, coxsackievírus e enterovírus (INTERNATIONAL COMMITTEE ON TAXONOMY OF VIRUSES - ICTV, 2013).

Os enterovírus humanos foram originalmente classificados com base em suas atividades biológicas, nas doenças por eles causadas e nos sintomas a eles relacionados. Os isolados foram numerados sequencialmente e classificados dentro dos grupos Coxsackievírus A, B, ou Echovírus, à medida em que eram identificados. O esquema de classificação original, porém, foi derrubado com a identificação de vírus sorologicamente idênticos, mas associados a diferentes graus de patogenicidade em camundongos. Esta e outras inconsistências levaram a uma nova classificação numérica dos sorotipos de enterovírus, começando pelo enterovírus 68 (OBERSTE; PALLANSCH, 2003; PALLANSCH; ROOS, 2007).

Apesar da importância das propriedades antigênicas, a introdução de técnicas de sequenciamento molecular levou ao desenvolvimento da classificação atual, que divide os membros do gênero Enterovírus em espécies com base na organização do genoma e similaridade nucleotídica, assim como nas propriedades biológicas (OBERSTE; PALLANSCH, 2003; PALLANSCH; ROOS, 2007).

\subsubsection{Replicação viral}

A replicação dos membros da família Picornaviridae ocorre no citoplasma da célula hospedeira. Inicialmente a partícula viral liga-se a um receptor celular, o que provoca alterações estruturais no capsídeo do vírus, culminando na liberação do genoma. Diferentes moléculas de superfície são utilizadas como receptores, e algumas são compartilhadas entre membros da família Picornaviridae e outras famílias virais. Como exemplos podem ser citados a proteína de superfície CD55, receptor comum para determinados coxsackievírus A e $\mathrm{B}$, echovírus e enterovírus, a proteína $\mathrm{CD} 155$, receptor compartilhado por poliovírus e alfaherpesvírus, e o receptor CAR (Coxsackievirus and Adenovirus receptor), comum para coxsackievírus do sorotipo B e adenovírus (COHEN et al., 2001). Pode ser necessário apenas um receptor para a entrada do vírus na célula, mas em alguns casos, a presença de um correceptor é fundamental (RACANIELLO, 2007).

Após sua liberação no citoplasma, a fita positiva de RNA é transcrita, permitindo a produção de proteínas necessárias à replicação do genoma e à formação de novas partículas do vírus. As proteínas virais são sintetizadas a partir de uma poliproteína precursora, clivada 
logo no início da replicação. Entre as proteínas sintetizadas está a RNA polimerase viral RNA-dependente, entre outras, necessárias à replicação do genoma do vírus e à síntese de RNA mensageiro. Inicia-se, então, a produção de RNA intermediário de fita negativa a partir do RNA de fita positiva já existente. A seguir, novas moléculas de RNA de fita positiva são produzidas. Tais eventos ocorrem em pequenas vesículas no citoplasma celular, e uma vez que as proteínas do capsídeo tenham sido produzidas de forma suficiente, inicia-se sua montagem. Ocorre a clivagem da proteína precursora de superfície P1, e é formado um precursor imaturo que se organiza em pentâmeros, aos quais são associadas as novas moléculas de RNA de fita positiva, originando, enfim, as partículas infecciosas (PALLANSCH; ROSS, 2007; RACANIELLO, 2007).

Um único ciclo de replicação viral pode levar de 5 a 10 horas para ser concluído, o que depende das particularidades da cepa viral envolvida, da célula hospedeira, da multiplicidade da infecção, além de fatores como temperatura e pH. A infecção produtiva das células provoca alterações morfológicas características, que incluem a condensação da cromatina, a proliferação de vesículas membranosas, o vazamento do conteúdo intracelular e a lise celular. A liberação dos vírus pode permitir a observação de efeito citopático claro, embora alguns membros da família Picornaviridae, como o vírus da Hepatite A, sejam liberados da célula sem produzir efeito detectável (PALLANSCH; ROSS, 2007; RACANIELLO, 2007).

\subsubsection{Epidemiologia}

Os enterovírus estão associados a um amplo espectro de doenças, incluindo meningites, encefalites, poliomielite, miocardites, infecções gastrointestinais entre outras (CHADWICK, 2006; PALLANSCH; ROOS, 2007).

Vários fatores incluindo idade, sexo e posição socioeconômica possuem efeitos com relação ao surgimento de surtos epidêmicos de infecções causadas pelos enterovírus humanos. Dentre estes fatores, a idade se destaca como determinante, pois faixas etárias distintas apresentam diferentes graus de susceptibilidade à infecção, gravidade da enfermidade, manifestações clínicas e prognóstico (PALLANSCH; ROOS, 2007).

As infecções por enterovírus apresentam sazonalidade melhor definida em regiões de clima temperado, ocorrendo em maior quantidade no verão e início do outono. Em países tropicais, no entanto, estes vírus podem ser observados durante todo o ano (CHADWICK, 2006; IRANI, 2008; LOGAN; MacMAHON, 2008). 
A transmissão dos enterovírus varia de acordo com a configuração de cada espécie e com o meio ambiente envolvido. Contudo, a via fecal-oral é a mais importante, com destaque também, para a via respiratória, observada em menor frequência. A transmissão fecal-oral pode predominar em áreas com condições sanitárias precárias, enquanto a transmissão respiratória pode ser importante em áreas mais desenvolvidas (PALLANSCH; ROOS, 2007).

As infecções do SNC causadas por enterovírus têm sido relatadas por diversos autores em todo o mundo, atingindo todas as faixas etárias, mas principalmente crianças e jovens, estando diretamente relacionadas à presença de aglomerados populacionais e a condições sanitárias inadequadas. Os enterovírus são responsáveis por cerca de 80 a $90 \%$ dos casos de infecção do SNC (IRANI, 2008; KUMAR, 2005; LOGAN; MacMAHON, 2008).

O quadro clínico de meningite causada pelos enterovírus, além dos sintomas comuns às meningites em geral, inclui sinais inespecíficos como manifestações gastrointestinais, respiratórias, mialgia e erupções cutâneas. A duração da doença é, geralmente, menor que uma semana (CHADWICK, 2006). Apesar de o curso das meningites causadas pelos enterovírus ser geralmente benigno, a morbidade é significativa, com considerável impacto em termos de internações e período de afastamento do trabalho. Complicações mais severas desta enfermidade estão relacionadas aos pacientes imunodeprimidos (CHADWICK, 2006).

A ocorrência de epidemias associadas aos enterovírus obedece à variação de sorotipos, tempo e localização geográfica, sendo a última de grande importância em casos de surtos, que podem ficar restritos a um pequeno grupo de pessoas ou estender-se a toda uma região ou país. Dentre os sorotipos descritos como responsáveis por surtos podem ser citados os echovírus (4, 6, 9, 13, 16 e 30), enterovírus (71, 75, 76 e 89), os poliovírus, e os coxsackievírus dos grupos A (7, 9 e 24) e B (1 a 6) (CASAS et al., 1997; CHAMBON et al., 2001; GOMES; KOPECKA; LINHARES, 2001; HANDIQUE, 2011; HOSOYA et al., 1998; SÃO PAULO, 2006; TYLER, 2009; WENG et al., 2010).

Devido ao advento da vacinação contra a poliomielite, os poliovirus estão cada vez menos associados às infecções do SNC, sendo verificados em apenas 1 a 2\% das ocorrências, ao contrário do observado no caso dos enterovírus não-pólio, cada vez mais identificados como agentes etiológicos destas infecções (ROTBART, 1995). 


\subsubsection{Adenovírus}

Os adenovírus foram inicialmente isolados por Rowe e colaboradores (1953), que ao cultivarem linhagens primárias de adenoides e tonsilas removidas cirurgicamente de crianças, observaram sua degeneração, sugerindo a presença de vírus nestas culturas. Em 1954, Hilleman e Werne, em estudo envolvendo recrutas americanos com quadro de infecção respiratória, isolaram, a partir das secreções colhidas, um agente capaz de causar alterações citopáticas em culturas de células humanas. Tais agentes também foram associados, mais tarde, a processos de degeneração da adenoide, febre faringo-conjuntiva e infecção respiratória aguda. Em 1956, Enders e colaboradores atribuíram a estes vírus o nome de adenovírus, devido ao tecido no qual haviam sido inicialmente observados.

\subsubsection{Características da partícula viral e taxonomia}

Os adenovírus são vírus de simetria icosaédrica, não envelopados, com cerca de 70 a $90 \mathrm{~nm}$ de diâmetro. O capsídeo viral é composto por 252 capsômeros, e as principais proteínas presentes são hexon, penton-base e fibra, que correspondem a $87 \%$ da partícula viral, sendo a proteína hexon predominante, responsável pela constituição de 240 dos 252 capsômeros totais, formando as faces do icosaedro. As proteínas penton-base e fibra constituem os 12 capsômeros restantes e formam os vértices do vírus numa estrutura denominada penton (BERK, 2007; JIANG, 2006; WOLD; HORWITZ, 2007).

O material genético dos adenovírus é composto por DNA de fita dupla linear associado a proteínas, contendo cerca de $36 \mathrm{~Kb}$. As partículas virais não apresentam envoltório lipoproteico, e são estáveis em solventes orgânicos como o éter. São, também, estáveis à temperatura ambiente por até duas semanas, a $36{ }^{\circ} \mathrm{C}$ por até sete dias e por pelo menos 70 dias a $4{ }^{\circ} \mathrm{C}$. Suportam uma ampla faixa de $\mathrm{pH}(5,0$ a 9,0$)$ e são muito resistentes à radiação ultravioleta (UV). Todas estas características contribuem para sua elevada estabilidade no ambiente (JIANG, 2006). 
Figura 5 - Representação esquemática e fotomicrografia eletrônica da partícula de adenovírus.

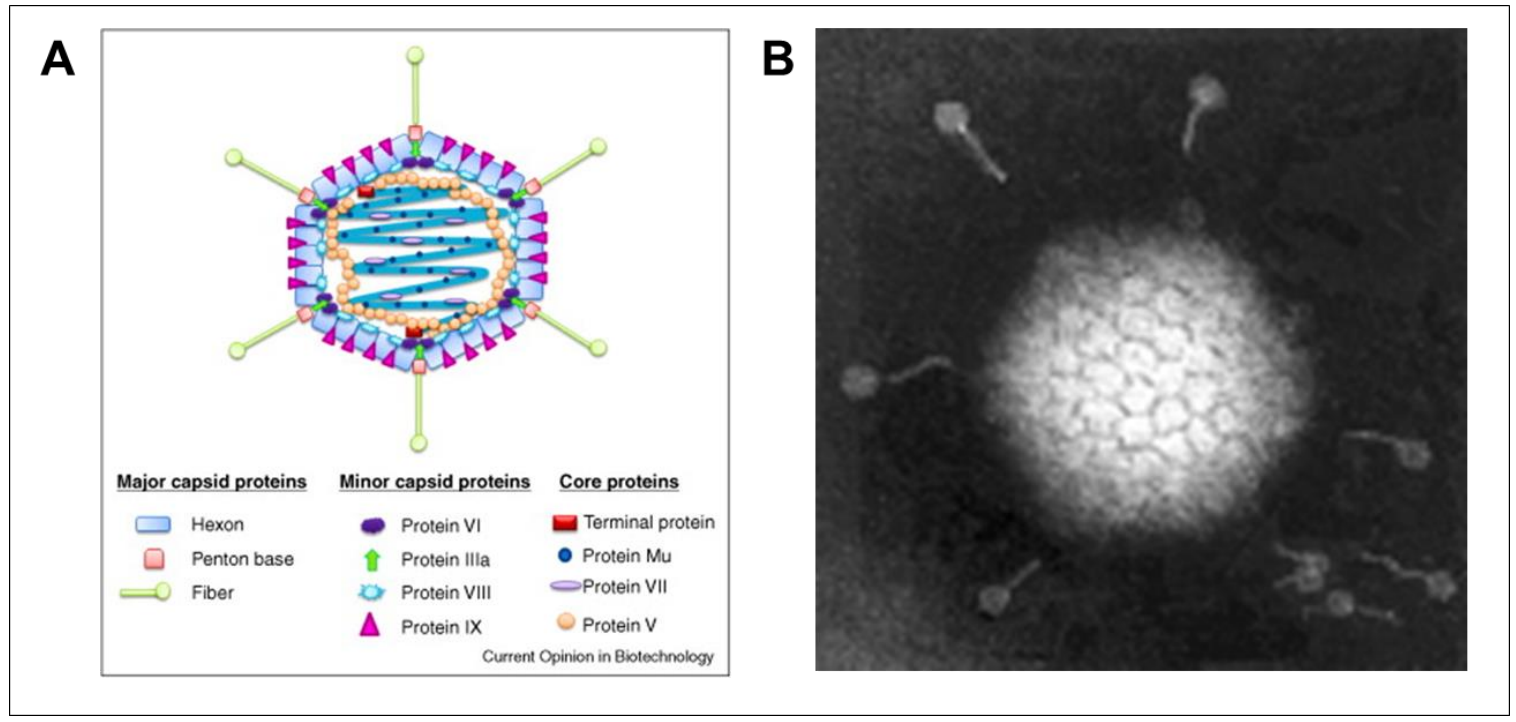

(A): Representação esquemática de uma partícula de adenovírus. (B): microscopia eletrônica da partícula de adenovírus.

Fontes: Chailertvanitkul e Pouton, 2010; http://web.uct.ac.za/depts/mmi/stannard/adeno.html.

Os adenovírus pertencem à família Adenoviridae, a qual contém cinco gêneros: Atadenovirus, composto por vírus que infectam ruminantes, marsupiais e aves, Aviadenovirus, constituído por vírus que infectam apenas aves, Ichtadenovirus, gênero criado recentemente devido às características de um novo adenovírus presente em uma espécie de peixe conhecido como esturjão (Acipenser ssp.), Siadenovirus, composto por vírus que infectam aves, peixes e anfíbios, e Mastadenovirus, no qual estão incluídos os vírus que infectam mamíferos (BERK, 2007; ICTV, 2013).

O gênero Mastadenovirus é composto por vinte e cinco espécies, das quais sete infectam humanos (Human adenovirus A a G). Os 54 sorotipos associados a infecções em seres humanos estão divididos entre as espécies acima citadas de acordo com a homologia do DNA, características morfológicas, propriedades biológicas e bioquímicas (BERK, 2007; ICTV, 2013).

\subsubsection{Replicação viral}

O ciclo de replicação dos adenovírus é dividido em duas fases. A primeira, denominada fase precoce, inclui a adsorção viral (mediada pela interação da proteína fibra com o receptor CAR - Coxsackievirus and Adenovirus receptor), a penetração do vírus na 
célula (via endocitose mediada por clatrinas), o transporte do vírus até o núcleo celular, a penetração do DNA viral no núcleo (mediada pela interação da proteína hexon com proteínas do complexo do poro nuclear), e a transcrição e expressão de genes precoces. Estes eventos modulam as funções celulares de forma a facilitar a replicação do DNA viral e a expressão dos genes tardios. Em células HeLa infectadas com adenovírus, esta fase inicial dura entre 5 e 6 horas. Após esta fase inicia-se, então, a efetiva replicação do DNA viral (BERK, 2007).

Concomitantemente ao início da replicação do DNA viral, inicia-se a fase tardia do ciclo, com a expressão de genes virais tardios e montagem dos novos vírus. A montagem da progênie viral é acompanhada da alteração da permeabilidade da membrana nuclear, necessária para a liberação dos vírus recém-formados para o citoplasma, e posterior desintegração da membrana citoplasmática, culminando na liberação dos vírus a partir da célula hospedeira (BERK, 2007; RUSSEL, 2000; TOLLEFERSON et al., 1996). O processo de lise celular encontra-se bem descrito para os adenovírus da espécie C, mas não pode ser aplicado a todas as espécies (SIQUEIRA-SILVA et al., 2009).

\subsubsection{Epidemiologia}

Os adenovírus humanos são responsáveis por diversas patologias, que acometem adultos e crianças, incluindo infecções respiratórias, oculares, gastrointestinais, urinárias e do SNC. As infecções do SNC causadas por adenovírus, embora não ocorram com grande frequência, incluem: meningites, mielites e encefalites (JIANG, 2006; SINANIOTIS, 2004; STRAUSSBERG et al., 2001; TEBRUEGGE; CURTIS, 2012).

As infecções causadas por adenovírus podem variar de esporádicas a epidêmicas (WOLD; HORWITZ, 2007). A disseminação do vírus pode ocorrer através do sistema respiratório, mas também através da eliminação prolongada pelas das fezes. Muitos dos sorotipos de adenovírus são capazes de se multiplicar no intestino delgado, embora os sorotipos da espécie $\mathrm{F}$ sejam os mais intimamente associados a quadros de gastroenterites (GRIMWOOD et al., 1995; WOLD; HORWITZ, 2007). Os adenovírus são considerados a segunda causa em importância nos casos de gastroenterites na infância (JIANG, 2006).

Com relação às infecções respiratórias, merecem destaque os sorotipos 7 e 3, ambos acometendo crianças menores de um ano e adultos jovens (IKEDA et al., 2003; WADELL, 1984). Estes sorotipos também estão presentes de forma importante na etiologia das infecções do SNC associadas aos adenovírus, embora outros sorotipos como o 26 tenham sido 
detectados como agentes etiológicos destas infecções (DUBBERKE et al., 2006; LEVY; NITZAN; BEHARAB, 1986; SANTOS, 2009; STRAUSSBERG et al., 2001).

\subsubsection{Herpesvírus humanos dos tipos 1 e 2}

Uma breve revisão histórica permite identificar, na literatura, relatos antigos das lesões associadas aos herpes simples, já mencionadas por Hipócrates em seus estudos. A natureza da infecção tem sido descrita há cerca de dois séculos, inclusive a transmissão interpessoal do vírus. Provavelmente são de John Astruc, médico que viveu na época do Rei Luis XIV, os mais relevantes relatos da nossa era, quando descreveu pela primeira vez quadros de herpes genital observados em prostitutas francesas (ROIZMAN; KNIPE; WHITLEY, 2007).

Os herpesvírus simples foram reconhecidos como agentes infecciosos apenas no final do século XIX. Burnet e Williams (1939) foram os responsáveis pelo estabelecimento da visão moderna das infecções por herpes simples, afirmando que, uma vez adquirido, o vírus pode permanecer no hospedeiro durante toda a vida, em estado de latência na maior parte do tempo, mas podendo ser reativado sob determinados estímulos, levando ao reaparecimento das lesões (ROIZMAN; KNIPE; WHITLEY, 2007).

Os herpes simples foram os primeiros herpesvírus humanos a serem descobertos, e constituem alguns dos vírus mais intensamente estudados. Merecem atenção suas propriedades biológicas, sua habilidade de causarem uma variedade de infecções, e a já mencionada possibilidade de permanecerem em estado de latência no hospedeiro, podendo ser reativados sob determinadas circunstâncias, causando lesões nos mesmos locais ou muito proximamente aos sítios da primeira infecção. Estes vírus servem como ferramentas para o estudo de translocação de proteínas, conexões sinápticas do sistema nervoso, estruturas de membrana, regulação gênica e terapia do câncer (ROIZMAN; KNIPE; WHITLEY, 2007).

Apenas em 1962 Schneweiss demonstrou a presença de dois sorotipos de hespesvirus simples (HSV): HSV-1 e HSV-2, atualmente designados como herpesvírus humanos do tipo 1 (HHV-1) e herpesvírus humanos do tipo 2 (HHV-2), de acordo com o proposto pelo International Committee on Taxonomy of Viruses (ICTV, 2013).

\subsubsection{Características da partícula viral e taxonomia}

A estrutura dos herpesvírus consiste no core, que contém o DNA viral, no capsídeo icosaédrico, que circunda o core, no tegumento, que circunda o capsídeo, e em um envoltório 
constituído de uma bicamada lipídica, no qual estão inseridas espículas virais (ROIZMAN; KNIPE; WHITLEY, 2007).

Seu genoma é composto por uma molécula de DNA de fita dupla, linear em sua maioria, embora uma pequena fração pareça ser circular, e contém aproximadamente 150.000 pb. O capsídeo icosaédrico é composto por 162 capsômeros. A face externa do capsídio é composta por quatro proteínas virais (VP5, VP26, VP23 E VP19C) (ROIZMAN; KNIPE; WHITLEY, 2007).

Entre o capsídeo e a bicamada lipídica está o tegumento, estrutura de aparência fibrosa composta por cerca de 20 proteínas virais, e que pode distribuir-se de forma assimétrica. Localizada mais externamente à partícula viral, a bicamada lipídica é proveniente das membranas do hospedeiro, e nela encontram-se inseridas glicoproteínas virais. A partícula viral pode medir cerca de 120 a 300nm, variando de acordo com a espessura do tegumento e características do envoltório (ROIZMAN; KNIPE; WHITLEY, 2007).

Figura 6 - Representação esquemática e fotomicrografia eletrônica da partícula de herpesvírus.

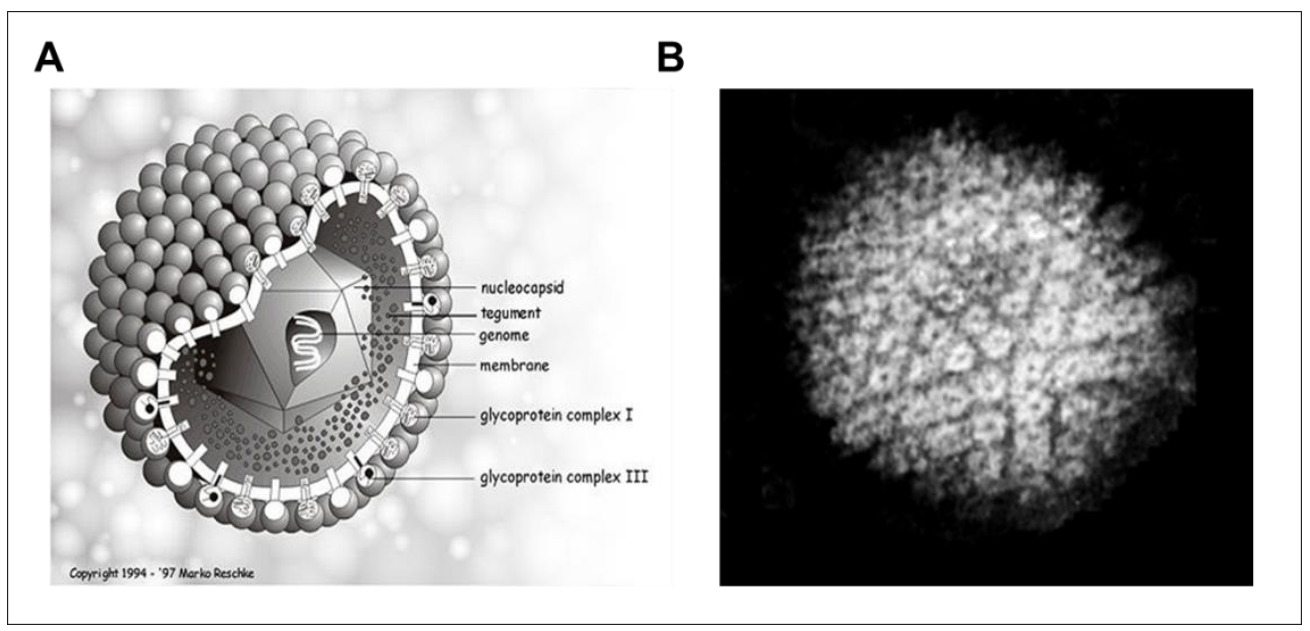

(A): Representação esquemática de uma partícula de herpesvírus. (B): microscopia eletrônica da partícula de herpesvírus.

Fonte: http://web.uct.ac.za/depts/mmi/stannard/herpes.html. 
Figura 7 - Fotomicrografia eletrônica da partícula de herpesvírus: estrutura viral.

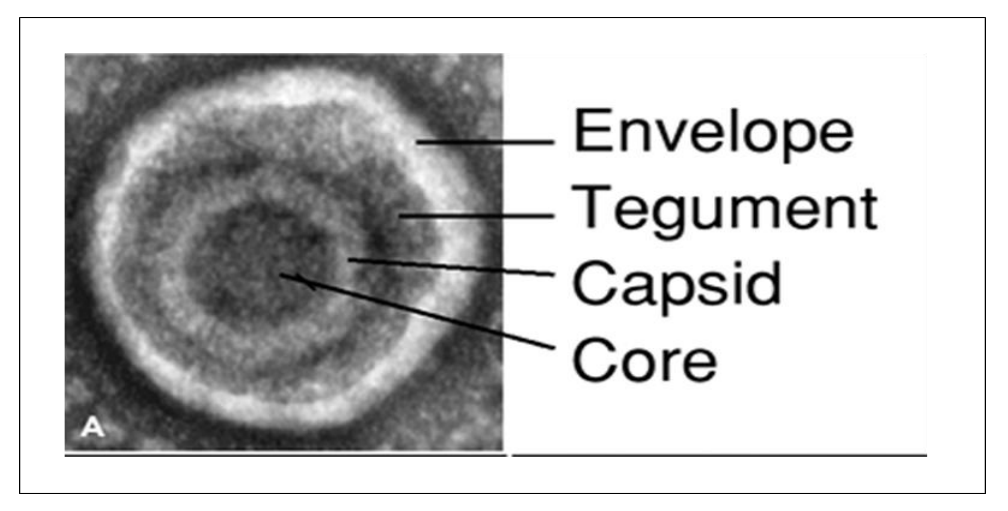

Fonte: Roizman, Knipe e Whitley, 2007.

De acordo com o ICTV (2013), a família Herpesviridae está dividida em três subfamílias: Alphaherpesvirinae, Betaherpesvirinae e Gammaherpesvirinae.

A subfamília Alphaherpesvirinae contém, entre outros, o gênero Simplexvirus, no qual estão classificados os Human herpesvirus 1 e Human herpesvirus 2, e o gênero Varicellovirus, no qual está incluído o Human herpesvirus 3 (conhecido como Varicela Zoster vírus) (ICTV, 2013).

A subfamília Betaherpesvirinae contém, entre outros, o gênero Cytomegalovirus, no qual está incluído o Human herpesvirus 5 (conhecido como Citomegalovírus), e o gênero Roseolovirus, no qual estão incluídos os Human herpesvirus 6 e 7 (ICTV, 2013).

A subfamília Gammaherpesvirinae contém, entre outros, o gênero Lymphocriptovirus, no qual está incluído o Human herpesvirus 4 (conhecido como Epstein-Baar vírus), e o gênero Rhadnovirus, no qual está incluído o Human herpesvirus 8 (ICTV, 2013).

\subsubsection{Replicação viral}

A replicação dos herpesvírus humanos dos tipos 1 e 2 (usualmente denominados herpesvírus simples), inicia-se com a interação entre as glicoproteínas presentes no envoltório viral e os receptores celulares. A seguir, ocorre a fusão do envoltório viral à membrana celular, culminando com a liberação da estrutura composta pelo tegumento e capsídeo virais no citoplasma da célula, os quais são, em seguida, transportados para o núcleo, onde é liberado o DNA viral, que atinge seu interior após ser transportado através de poros nucleares (ROIZMAN; KNIPE; WHITLEY, 2007). 
As etapas seguintes ocorrem no núcleo da célula, incluindo a transcrição do genoma viral, replicação do DNA viral e montagem dos novos capsídeos. Durante a infecção produtiva, o DNA do vírus é transcrito pela RNA polimerase II da célula hospedeira, mas com a interferência dos componentes virais em todos os estágios da infecção. A transcrição do genoma viral e a síntese de proteínas virais ocorrem de maneira regulada, em etapas. Inicialmente são expressos os genes cuja transcrição não está associada à síntese de novas proteínas virais, mas de proteínas precoces imediatas, envolvidas na regulação da transcrição gênica, incluindo a expressão dos genes precoces. A seguir, como resultados desta última expressão, são produzidas enzimas e proteínas de ligação ao DNA envolvidas na replicação do material genético viral. Após a replicação do DNA viral, ocorre a transcrição dos genes tardios, com síntese de proteínas tardias, com função principalmente estrutural, associadas à montagem das partículas virais (ROIZMAN; KNIPE; WHITLEY, 2007).

Para a montagem dos novos vírus, o DNA viral é acondicionado dentro dos capsídeos pré-montados. O nucleocapsídeo torna-se maduro e adquire infectividade através de sua passagem pela lamela interna da membrana nuclear. Existe um consenso geral de que os herpesvírus adquiram seu envoltório neste momento. É fundamental, no entanto, que porções da membrana nuclear interna sejam modificadas pelas glicoproteínas virais. Não há, contudo, um consenso sobre o trajeto seguido pelos vírus entre as membranas nucleares interna e externa, bem como sua liberação no espaço extracelular (ROIZMAN; KNIPE; WHITLEY, 2007).

São propostas três vias de liberação dos herpesvírus. A primeira propõe a ocorrência de um duplo envelopamento viral, no qual os nucleocapsídeos adquirem o primeiro envoltório através da passagem pela membrana nuclear interna, o qual é perdido durante a passagem pela membrana nuclear externa, seguido de novo envelopamento devido à fusão com membranas presentes no citoplasma celular, incluindo as do complexo de Golgi, sendo transportados através de vesículas que se fundem à membrana citoplasmática, permitindo a liberação do vírus envelopado no espaço extracelular. O segundo modelo sugere que o nucleocapsídeo adquira o envoltório durante a passagem pela membrana nuclear interna, seja englobado por uma vesícula na membrana nuclear externa, e levado até à membrana citoplasmática, à qual se funde a vesícula permitindo a liberação do vírus. A terceira proposta sugere que o nucleocapsídeo seja liberado do núcleo através de poros nucleares e adquira o envoltório através de vesículas citoplasmáticas, que transportam o vírus até a membrana celular, através da qual é liberado (DA COSTA et al., 2000; METTENLEITER, 2002; ROIZMAN; KNIPE; WHITLEY, 2007; WILD et al., 2005). O processo completo de replicação dos herpesvírus 
observadas em culturas de células completamente permissivas dura, aproximadamente, 18 a 20 horas (ROIZMAN; KNIPE; WHITLEY, 2007).

\subsubsection{Epidemiologia}

As infecções associadas aos herpesvírus simples, atualmente denominados herpervírus humanos 1 e 2 (HHV-1 e HHV-2) de acordo com o ICTV (2013), são frequentes em todo o mundo. De acordo com estudos soroepidemiológicos, mais de $90 \%$ da população em geral apresenta anticorpos contra pelo menos um dos vírus acima citados (LUPI; SILVA; PEREIRA, 1996, 2000).

As manifestações clínicas dos herpesvírus dos tipos 1 e 2 variam de acordo com o sítio de inoculação do vírus, a imunidade do hospedeiro e a cepa viral adquirida. A primeira infecção é geralmente assintomática ou apresenta sintomas inespecíficos. O quadro clássico de infecção benigna é caracterizado pelo surgimento de máculas eritematosas no local da inoculação viral, acompanhadas de ardor, prurido e dor, além de vesículas, compondo um quadro que dura de duas a três semanas. No caso do herpes genital as complicações locais mais comuns são as infecções secundárias. Ambas as cepas virais podem causar infecção genital ou orolabial, porém com diferentes frequências (LUPI; SILVA; PEREIRA, 2000).

Após a primeira infecção o vírus pode permanecer latente, e fatores como imunodepressão, alterações hormonais, exposição à radiação ultravioleta, e estados de depressão e ansiedade, podem causar a reativação viral (LUPI; SILVA; PEREIRA, 2000).

A principal forma de contágio observada para estes vírus é o contato com lesões e secreções contaminadas. No entanto, indivíduos assintomáticos podem ser, também, responsáveis pela transmissão do vírus pela saliva ou secreções respiratórias. A infecção por HHV-1 tem ocorrido de forma cada vez mais precoce na população, e sua forma latente pode ser observada em indivíduos cada vez mais jovens. A incidência estimada destes vírus é de cerca de 1,5\% ao ano, e a prevalência varia de $70 \%$ na Europa até 95\% na América Central, África e Ásia. No Rio de Janeiro a prevalência observada na população é de 86\% (LUPI; SILVA; PEREIRA, 1996, 2000; ROIZMAN; KNIPE; WHITLEY, 2007).

No caso do HHV-2 a prevalência observada é bem menor, variando de 13 a 52\% nos Estados Unidos, 10 a 27\% na Europa e bastante alta na África e Austrália, podendo chegar a $40 \%$ da população. No Brasil, em estudo realizado no Rio de Janeiro em uma população de doadores de sangue voluntários, a soroprevalência observada foi de $29 \%$, mas apenas $7 \%$ relataram a ocorrência prévia de infecção genital. A prevalência do HHV-2 tende a aumentar 
com a idade, e a frequência destas infecções está relacionada à vida sexual do paciente (NAHMIAS; LEE; BECKMAN-NAHMIAS, 1990).

Os HHV-1 e HHV-2 estão também associados a infecções do SNC, consistindo nas causas mais comuns de encefalites em adultos e crianças. Podem, também, ser observados quadros de meningites, mielites e radiculites. A encefalite, no entanto, consiste no quadro mais importante, e está relacionada a altas taxas de mortalidade, que podem chegar a 70\% sem tratamento adequado (CHADWICK, 2006). A encefalite herpética não apresenta sazonalidade definida nem está mais frequentemente associada à determinada idade ou sexo (BULAKBASI; KOCAOGLU, 2008).

Alguns autores afirmam que o HHV-1 é responsável pelo quadro de encefalite em mais de $90 \%$ dos casos, enquanto o restante está relacionado ao HHV-2. Já os casos de meningite são mais frequentemente associados ao HHV-2, mesmo sem a precedência de episódios de herpes genital. O HHV-2 também tem sido associado à meningite de Mollaret, doença definida por episódios recorrentes de meningite asséptica (BERGER; HOUFF, 2008). As meningites causadas por este vírus estão mais frequentemente associadas a complicações que as relacionadas a outras etiologias virais (CHADWICK, 2006).

Os HHV-2, quando associados a doenças neurológicas, podem resultar da primeira infecção, fato mais comumente observado em neonatos ou, após este período, durante a fase sexualmente ativa do indivíduo (BERGER; HOUFF, 2008).

Com relação às encefalites, cerca de um terço dos casos observados em pacientes de 6 meses a 20 anos é consequência da primeira infecção. Aproximadamente metade dos casos em pacientes com mais de 50 anos é consequência da reativação viral (BULAKBASI; KOCAOGLU, 2008).

\subsection{Infecções do sistema nervoso central}

Dentre os processos inflamatórios que acometem o SNC estão as meningites, as encefalites, as mielites, as meningoencefalites e as encefalomielites. Podem ser causadas por bactérias, vírus e fungos, entre outros agentes infecciosos, e também por agentes não infecciosos, como traumatismos, drogas ou substâncias tóxicas (IRANI, 2008).

O SNC deve ser considerado um compartimento particular, de acesso altamente restrito, isolado da circulação sistêmica. Está envolvido por uma camada celular conectada firmemente entre si através de junções oclusivas conhecidas como tight junctions, formando 
duas barreiras fundamentais para sua homeostase: a barreira hematoencefálica e a barreira hematoliquórica (DE VRIES et al., 1997; LIN; SÁ, 2002).

Quando o processo inflamatório é restrito às meninges, membranas que envolvem o encéfalo e a medula espinhal, recebe o nome de meningite. A encefalite é caracterizada pela inflamação do parênquima cerebral, enquanto a mielite envolve processos inflamatórios da medula espinhal. Meningoencefalites e encefalomielites são combinações dos termos acima citados que indicam quadros mais amplos de inflamação do SNC, envolvendo, simultaneamente, as meninges e o parênquima cerebral ou o parênquima cerebral e a medula espinhal, respectivamente (IRANI, 2008; LOGAN; MacMAHON, 2008; SOMAND; MEURER, 2009).

Patológica e clinicamente observa-se uma continuidade entre as meninges e as estruturas envolvidas por elas, o que torna não tão exatas as definições expostas acima. $\mathrm{Na}$ prática clínica, podem ser observados diferentes níveis de acometimento de uma ou outra estrutura simultaneamente. Algum grau de inflamação meníngea pode ser observado nas encefalites, assim como determinado grau de inflamação do parênquima cerebral pode ser observado nas meningites (KUMAR, 2005).

\subsection{Patogênese e disseminação dos vírus neurotrópicos}

Embora o SNC esteja protegido por um elaborado sistema de barreiras, que incluem a barreira hematoencefálica e a barreira hematoliquórica, muitos vírus têm desenvolvido estratégias para atingi-lo causando infecções.

As formas de invasão do SNC variam de acordo com o vírus envolvido. Os vírus neurotrópicos seguem as rotas gerais de entrada no organismo: os enterovírus invadem o organismo via trato gastrointestinal; os herpesvírus e o HIV podem romper membranas mucosas da boca e do trato genital; os arbovírus são transmitidos através de vetores e geralmente penetram no organismo através da picada de um mosquito; o vírus da raiva pode ser transmitido através da mordida de um animal infectado, e são vários os vírus neurotrópicos transmitidos através de sangue ou instrumentos contaminados. São conhecidas três principais vias de entrada no SNC: através do endotélio vascular, através de leucócitos infectados ou por meio de nervos periféricos (McGAVERN; KANG, 2011).

Vários vírus como o JC, o vírus Epstein-Baar, o HTLV1, o vírus West Nile e até mesmo os poliovírus parecem ser capazes de infectar diretamente o endotélio vascular cerebral in vitro. Em muitos casos, a infecção provoca alterações nas células endoteliais e nas 
junções de membrana, promovendo o aumento da permeabilidade vascular. In vivo, os vírus parecem, também, invadir as células endoteliais através da ligação a proteínas por elas expressas (McGAVERN; KANG, 2011).

Outra forma de entrada dos vírus no SNC é através de leucócitos infectados, que transportam os vírus da corrente sanguínea através da barreira hematoencefálica. A infecção de monócitos e macrófagos é considerada o principal mecanismo usado pelos "lentivírus" para migrar através das barreiras do SNC. Outros vírus como o JC podem ter a invasão facilitada pela infecção de leucócitos. Mesmo que as barreiras hematoencefálica e hematoliquórica regulem cuidadosamente a entrada de células imunes, os vírus têm desenvolvido estratégias de forma a invadir e se replicar no interior do SNC (McGAVERN; KANG, 2011).

Uma terceira forma de entrada dos vírus no SNC ocorre através dos nervos periféricos, sensoriais e motores, que podem se estender desde o centro até a periferia do sistema nervoso. Os poliovírus e o vírus da raiva podem ligar-se a neurônios da junção neuromuscular permitindo a expressão de receptores específicos para a ligação dos vírus. Além dos neurônios motores e sensoriais, os nervos olfatórios também constituem uma via de entrada dos vírus no SNC (IRANI, 2008; McGAVERN; KANG, 2011).

Após a entrada, muitos vírus utilizam o transporte via axônio (retrógrado e antirretrógrado) para movimentar-se dentro das células nervosas. Podem ser citados os poliovírus, os alfaherpesvírus, o vírus West Nile e o vírus da raiva (DIEFENBACH et al., 2008; McGAVERN; KANG, 2011; SALINAS; SCHIAVO; KREMER, 2010). O transporte célula a célula pode ocorrer através da liberação do vírus nas junções sinápticas, passagem através de microfusões entre as células ou através da liberação do vírus em determinadas regiões ao longo do axônio, possibilitando a infecção das células vizinhas (McGAVERN; KANG, 2011).

Vírus que invadem o SNC através da corrente sanguínea podem penetrar através da barreira hematoencefálica em regiões nas quais esta se apresenta mais vulnerável, como plexo coroide, glândula pituitária posterior e órgãos circunventriculares. Nestas áreas, observa-se a presença de endotélio fenestrado e membrana basal esparsa. Desta maneira, os vírus podem ser levados diretamente até o líquor (SANTOS, 2009).

Os enterovírus, após atingirem o trato gastrointestinal, infectam os enterócitos e atravessam a parede do intestino até atingirem as placas de Peyer (associadas ao tecido linfático), onde ocorre a primeira replicação. É observado um quadro de viremia que pode atingir vários tecidos, como fígado, pulmão, coração e SNC. Mesmo que este último não seja 
atingido nesse estágio, a replicação viral observada nos demais sítios pode produzir uma segunda viremia, responsável por provocar o envolvimento neurológico (IRANI, 2008).

Uma vez invadido o SNC, a infecção viral pode apresentar diferentes desfechos, que incluem infecção aguda, causada pela intensa replicação do vírus, persistência ou latência. A ocorrência de uma ou outra situação depende do tipo de vírus envolvido e seu título, da rota da infecção, da idade e das características genéticas do paciente e da atuação da resposta imune (CHAKRABORTY et al., 2010).

Embora o ideal seja a eliminação do vírus, estados de latência e persistência podem ser observados. Infecções persistentes são definidas pela replicação viral contínua, enquanto a latência é caracterizada pela minimização da produção de partículas infecciosas, ou até mesmo pela não replicação viral, embora o patógeno não seja eliminado. Durante a latência, o genoma viral permanece epissomal e a transcrição proteica é muito limitada. No entanto, em determinadas situações capazes de desencadear depressão imunológica, os vírus podem ser reativados, causando infecção produtiva e disseminação nos tecidos, com o aparecimento de sintomas mais intensos (CHAKRABORTY et al., 2010; McGAVERN; KANG, 2011).

\subsection{Características das infecções do sistema nervoso central}

\subsubsection{Manifestações clínicas}

Os quadros de meningite, tanto de etiologia bacteriana quanto viral, são caracterizados por febre, dor de cabeça, prostração, sinais de irritação meníngea, fotofobia, rigidez de nuca, náuseas e vômitos. No entanto, quadros não tão típicos podem ser observados, principalmente nos casos de meningite viral (ANDERSON, 1993; LOGAN; MacMAHON, 2008; ROOS, 2005).

São três os sinais de irritação meníngea: sinais de Kernig, Brudzinski e Lasègue. Em 1882 Kernig, percebeu que o indivíduo com irritação meníngea era incapaz de estender completamente os membros inferiores quando seu tronco era flexionado. Anos mais tarde, Brudzinski observou que nestes casos, a flexão passiva da cabeça em direção ao peito provocava flexão dos membros inferiores. O sinal de Lasègue é caracterizado pela flexão dos membros inferiores quando de sua elevação angular em direção ao quadril. (BRASIL, 2010; WALKER; LAWS; UDVARHELYI, 1998).

Nas infecções de etiologia bacteriana o quadro clínico apresentado pelo paciente é geralmente grave, e pode manifestar-se de forma drástica com a ocorrência da redução do 
nível de consciência, convulsões, choque e coma, podendo evoluir rapidamente para óbito. Nestas situações, a introdução da terapia com antibióticos, preconizada pelo Ministério da Saúde, é determinante para o bom prognóstico da doença. Pacientes não tratados apresentam progressiva deterioração do estado mental, e podem ocorrer complicações como distúrbios visuais, da audição e de linguagem, alterações neurológicas e anormalidades motoras (BRASIL, 2010; LOGAN; MacMAHON, 2008; ROOS, 2005).

As infecções virais, em geral, são caracterizadas pelo bom estado clínico do paciente, e podem apresentar sintomatologia mais leve e generalizada, envolvendo sintomas respiratórios ou gastrointestinais, mialgia e erupção cutânea, como observado nas meningites por enterovírus. Em grande parte dos casos a infecção desenvolve-se de forma benigna e autolimitada, com duração de cerca de uma semana, e o paciente recupera-se completamente sem a presença de complicações (BRASIL, 2010; LOGAN; MacMAHON, 2008; ROOS, 2005).

Em crianças pequenas, nas quais a meningite manifesta-se basicamente através de febre e irritabilidade, sem a evidência clara dos sinais de alteração meníngea, o cuidado deve ser redobrado. Podem ser observados choro agudo ou gemido, recusa alimentar e abaulamento da fontanela (LOGAN; MacMAHON, 2008; ROOS, 2005).

Quando há o envolvimento do encéfalo (encefalites e meningoencefalites), além dos sintomas já descritos são comuns alterações neurológicas e do estado mental. Estes quadros são extremamente graves e devem ser diagnosticados e tratados imediatamente.

\subsubsection{Características do líquor e alterações provocadas pelas infecções do sistema nervoso central}

O líquido cefalorraquidiano (LCR), ou líquor, é um fluído aquoso intimamente relacionado ao SNC e a seus envoltórios. É um ultra filtrado produzido pelos plexos coroides que circula pelo espaço intracraniano, preenchendo o sistema ventricular, o canal central da medula e os espaços subaracnóides craniano e raquiano, representando a maior parte do fluído extracelular do SNC (COMAR et al., 2009).

Entre suas funções podem ser citadas o fornecimento de nutrientes ao cérebro, a remoção de produtos da atividade neuronal e a proteção mecânica das células cerebrais. A homeostase do líquor é fundamental para a atividade neurológica (COMAR et al., 2009; JOHANSON et al., 2008; SKIPOR; THIERRY, 2008). 
A presença de tumores, infecções, traumas, isquemias e hidrocefalias, podem interferir na produção e na composição do líquor, o que torna sua análise laboratorial fundamental para o diagnóstico e acompanhamento das doenças neurológicas, inclusive das infecções virais e bacterianas. $\mathrm{O}$ exame do líquor vem sendo utilizado no diagnóstico desde o final do século XIX (COMAR et al., 2009; SKIPOR; THIERRY, 2008).

Em condições normais, o líquor é constituído por pequenas concentrações de proteínas, glicose, lactato, enzimas, potássio e magnésio, e concentrações relativamente altas de cloreto de sódio (DIMAS, PUCCIONI-SOHLER, 2008). Quanto à celularidade, apresenta, normalmente, até 4 células por milímetro cúbico, e constitui um fluído límpido e incolor, com aspecto de água de rocha (BRASIL, 2010).

Em condições patológicas, pode haver alteração do aspecto do líquor, que pode apresentar turvação devido ao aumento do número de células ou à proliferação de bactérias ou fungos. Quanto à cor, pode ser classificado como xantocrômico (coloração amarelada), devido à presença de bilirrubina plasmática associada à hemorragia subaracnóidea ou ao deslocamento de proteínas do soro para o líquor, ou eritrocrômico (coloração avermelhada), devido à hemólise das hemácias causada por acidente de punção ou à hemorragia subaracnóidea (DIMAS, PUCCIONI-SOHLER, 2008).

Nas infecções virais do SNC o líquor apresenta, geralmente, aspecto claro. Na maioria das vezes a contagem celular é inferior a 500 células $/ \mathrm{mm}^{3}$, com predomínio linfócitos, embora os polimorfonucleares (neutrófilos) possam predominar nas primeiras horas da infecção. Os níveis de proteínas apresentam-se normais ou ligeiramente aumentados, enquanto a glicose mantém-se inalterada. Algumas exceções são observadas em casos de infecção pelos herpesvírus 1 e 2 , nas quais pode ser verificada a presença de 50 a 800 células $/ \mathrm{mm}^{3}$, podendo chegar a 2.500 células $/ \mathrm{mm}^{3}$, além de elevação nos níveis proteicos, podendo atingir 100mg/dL, e possível diminuição da glicose no decorrer da infecção (ALMEIDA et al., 2007; ROOS, 2005).

O quadro a seguir resume as características normais do líquor e as alterações observadas em determinados estados patológicos de origem infecciosa: 
Quadro 2 - Características do líquor e alterações apresentadas em casos de infecção.

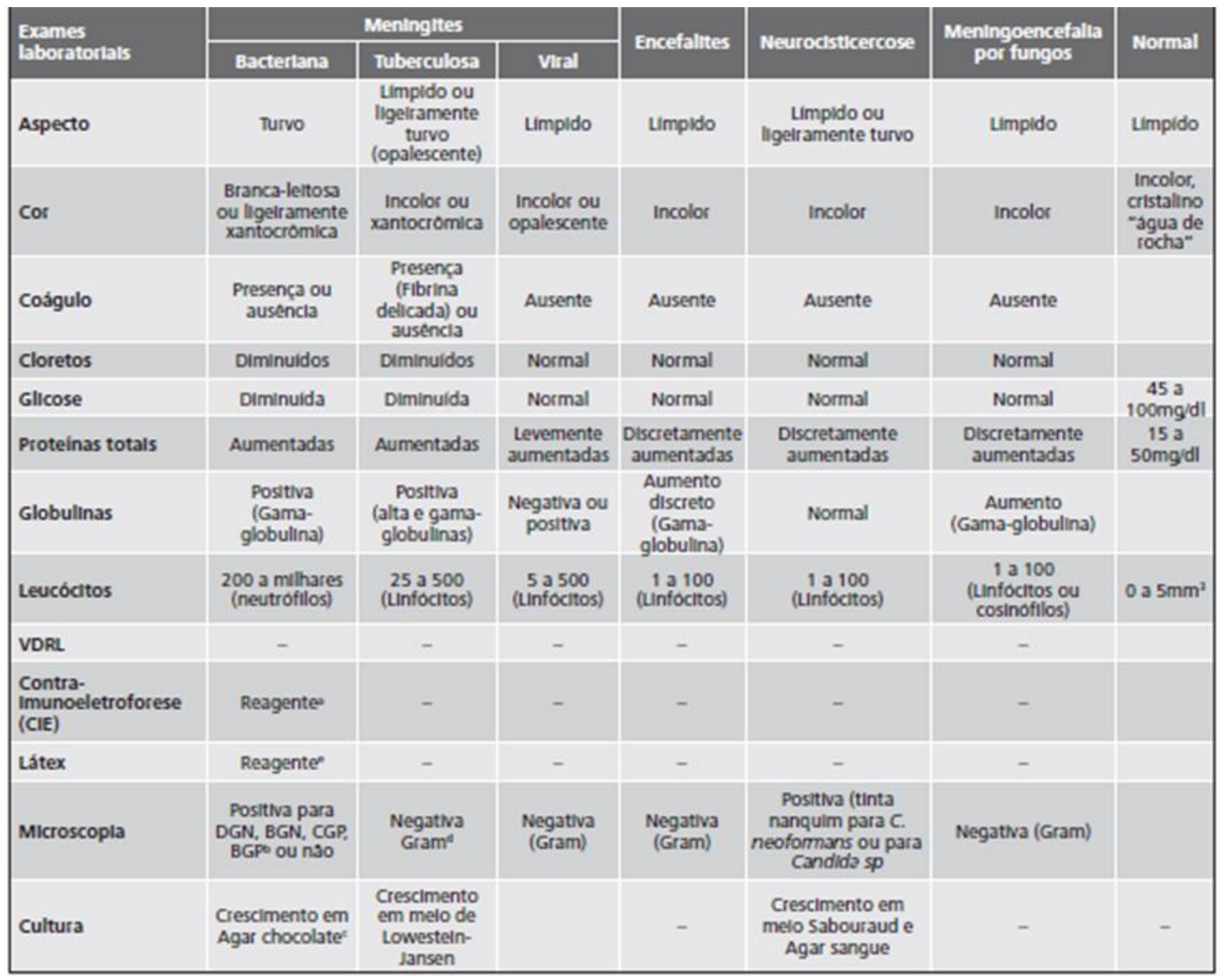

a) Contraimunoeletroforese (CIE) reagente para N. meningitidis, H. influenzae tipo b.

b) $\mathrm{DGN}=$ Diplococo gram-negativo; $\mathrm{BGN}=$ Bacilo gram-negativo; $\mathrm{CGP}=\mathrm{Cocos}$ gram-positivo; BGP = Bacilo gram-positivo.

c) Quando sem uso prévio de antibióticos e condições adequadas de coletas e semeadura do LCR.

d) Exame baciloscópico é de valor relativo por que a presença de BAAR é sempre pequena no LCR (Paucibacilar). A baciloscopia é feita com coloração de Ziehl-Neelsen

e) Látex = reagente para S. pneumoniae (grupos A e B), H. influenzae e N. meningitidis A, B, C, Y, W135 ou outros agentes dependendo do produto disponível.

Fonte: Brasil, 2010. 


\subsection{Diagnóstico das infecções virais do sistema nervoso central}

Considerando-se a relevância das infecções virais do SNC, torna-se fundamental o estabelecimento de métodos diagnósticos eficazes na detecção de seus agentes etiológicos, que contribuam efetivamente para o manejo adequado do paciente, incluindo a administração de drogas antivirais, quando indicadas, buscando a regressão do quadro infeccioso e minimizando o risco de sequelas. Os métodos diagnósticos clássicos, como o isolamento viral e sorologia, são muitas vezes ineficazes na determinação da etiologia viral das infecções do SNC, e são utilizados somente em laboratórios de referência para a confirmação diagnóstica e, principalmente, para a obtenção de dados epidemiológicos (CHADWICK, 2006; POLLAGE; PETTI, 2006).

A ausência de métodos adequados às exigências de um laboratório clínico, que busca ensaios rápidos e seguros faz com que, muitas vezes, o diagnóstico das infecções virais do SNC seja presuntivo, baseado no exame clínico, na análise quimiocitológica do líquor e na ausência de bactérias e fungos nas culturas das amostras clínicas. A detecção efetiva dos vírus, porém, não é realizada rotineiramente.

Em alguns casos, o diagnóstico por imagem, realizado através de tomografia computadorizada ou ressonância magnética, pode contribuir para a definição da etiologia da infecção (GUPTA et al., 2012).

Na tabela 1 são relatados os critérios utilizados para a confirmação das meningites assépticas notificadas no Brasil em 2011 e 2012. Nota-se que, em apenas poucos casos, a etiologia viral foi confirmada.

Tabela 1 - Critérios de confirmação das meningites assépticas no Brasil em 2011 e 2012.

\begin{tabular}{ccccccc}
\hline \hline $\begin{array}{c}\text { Critério de } \\
\text { confirmação }\end{array}$ & Clínico & Quimiocitológico & $\begin{array}{c}\text { Clínico- } \\
\text { epidemiológico }\end{array}$ & $\begin{array}{c}\text { Isolamento } \\
\text { viral }\end{array}$ & $\begin{array}{c}\text { PCR } \\
\text { viral }\end{array}$ & Total \\
\hline $\mathbf{2 0 1 1}$ & 641 & 7.067 & 228 & 36 & 93 & 8.065 \\
\hline $\mathbf{2 0 1 2}$ & 606 & 8.453 & 271 & 39 & 251 & 9.620 \\
\hline \hline
\end{tabular}

Fonte: DATASUS, 2013. 
As técnicas moleculares têm adquirido importância em virtude de sua alta especificidade, sensibilidade e rapidez, e são realizadas na rotina dos laboratórios de pesquisa. Sua aplicação em laboratórios clínicos, no entanto, ainda é muito discreta. Novos estudos, visando a sua implantação efetiva na rotina clínica, contribuiriam para um diagnóstico mais preciso das infecções virais do SNC (CINQUE; BOSSOLASCO; LUNDIKVIST, 2003; JEFFERY et al., 1997; POLLAGE; PETTI, 2006).

\subsubsection{Diagnóstico molecular das infecções do sistema nervoso central}

A introdução da reação em cadeia da polimerase (PCR) representou um importante progresso para a identificação da etiologia das infecções do SNC. A técnica de PCR foi desenvolvida nos anos 80 por Kary Mullis e possibilita a amplificação de fragmentos de DNA (ou cDNA) através da enzima DNA polimerase. Esta enzima sintetiza uma sequência complementar, desde que um pequeno fragmento (o iniciador ou primer) esteja ligado, de forma específica, a uma das cadeias do genoma alvo no ponto determinado para o início da síntese. Os iniciadores definem a sequência a ser replicada, e milhões de cópias são obtidas após a amplificação (MULLIS, 1990).

Quando se trata de amostras de líquor, nas quais um número mínimo de partículas virais pode ser responsável pela infecção, uma única reação de amplificação dos ácidos nucleicos pode não ser suficiente para a visualização através da eletroforese em gel de agarose. Neste sentido, a reação de Nested-PCR, que utiliza oligonucleotídeos internos aos utilizados na reação de PCR, e realiza uma reamplificação do produto inicial, pode ser fundamental para a detecção do material genético viral. Neste caso há o aumento da sensibilidade bem como da especificidade da reação, já que a utilização de um segundo conjunto de oligonucleotídeos reduz a possibilidade de ligação a sítios inespecíficos e sua consequente amplificação. A Nested-PCR, no entanto, não é indicada para o diagnóstico clínico de rotina, já que manipulação de produtos pós-amplificação aumenta as chances de contaminação entre as amostras, levando a resultados falso-positivos.

O surgimento de novas técnicas, em particular a PCR em tempo real, pode significar uma alternativa importante devido a sua sensibilidade, especificidade e rapidez, além do processamento da reação em sistema fechado, sem a necessidade do manuseio de produtos pós-amplificação. Além disso, a geração e leitura automatizada dos dados obtidos tornam os resultados mais confiáveis. A PCR em tempo real quantitativa possibilita estimar o número de 
cópias do alvo de interesse, que pode ser um gene ou um fragmento do genoma viral, por exemplo (COLIMON, 2002; DRAGO, 2004).

A PCR em tempo real requer uma plataforma de instrumentação, que inclui um termociclador, que deve estar acoplado a um sistema ótico para a excitação da fluorescência e detecção da luz emitida, e a um computador, no qual o software é responsável pela aquisição e análise final dos dados. A emissão dos fluoróforos aumenta à medida que a amplificação do material genético ocorre. $O$ ponto que detecta o ciclo no qual a reação atinge o início da fase exponencial, quando há um aumento de sinal associado à formação do produtos de PCR, é denominado Cycle Threshold $(\mathrm{Ct})$. A partir do valor de Ct pode ser construída a curva padrão, na qual o eixo x corresponde ao $\log$ da concentração do ácido nucleico (alvo) e o eixo y corresponde aos valores de $\mathrm{Ct}$.

Os sistemas de detecção mais comuns associados à PCR em tempo real são o $S y b r^{\circledR}$ Green e o sistema TaqMan $^{\circledR}$. A molécula de $S y b r^{\circledR}$ Green liga-se de maneira inespecífica a moléculas de fita dupla de DNA, e o aumento da fluorescência é observado à medida que ocorre a amplificação. Um problema inerente a este sistema é que o fluoróforo pode ligar-se a produtos inespecíficos, e a fluorescência emitida pode não representar a real amplificação do genoma alvo.

O sistema TaqMan $^{\circledR}$ é constituído de uma sonda marcada com um fluoróforo na posição 5' e com uma molécula denominada quencher na extremidade 3'. Enquanto a sonda permanece intacta, o quencher absorve a fluorescência emitida pelo fluoróforo. Durante a reação de amplificação, a sonda liga-se à sequência de DNA alvo e é degradada devido à atividade exonuclease 5'-3' da DNA polimerase, que separa o quencher do fluoróforo, permitindo a emissão de luz. Esta emissão aumenta de forma exponencial à medida que o material genético é amplificado. Neste caso, como a ligação da sonda ao alvo ocorre de maneira específica, ao contrário do observado no Sybr ${ }^{\circledR}$ Green, o aumento da fluorescência é fiel à amplificação da sequência desejada (HEID et al., 1996). A figura a seguir esquematiza os sistemas Syber ${ }^{\circledR}$ Green e TaqMan ${ }^{\circledR}$. 
Figura 8 - Esquema das reações envolvendo os sistemas Syber ${ }^{\circledR}$ Green e TaqMan ${ }^{\circledR}$.

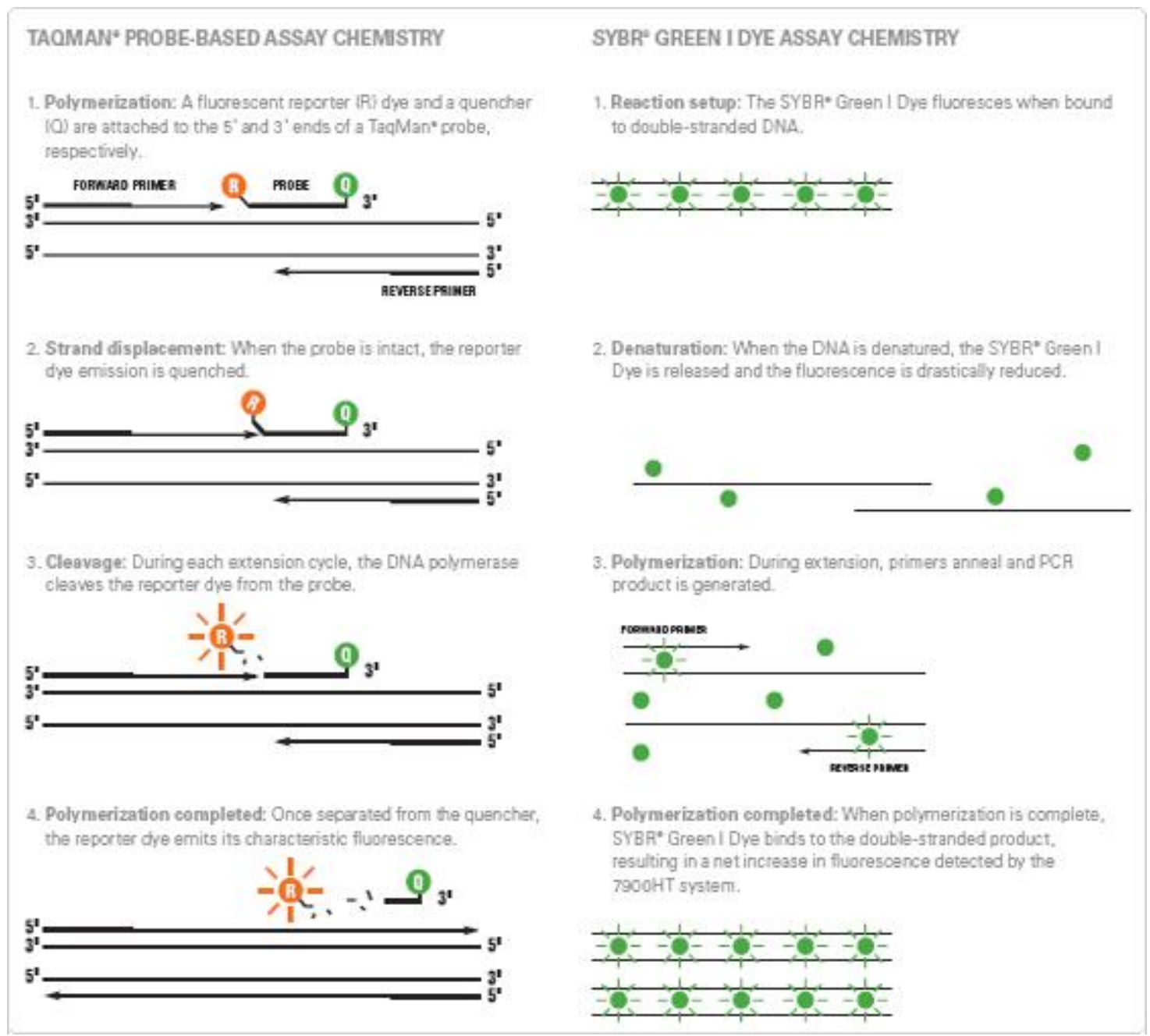

Fonte: http://www.invitrogen.com.

Muitos laboratórios de referência em todo o mundo têm padronizado reações de PCR para o diagnóstico complementar das infecções virais do SNC, em especial para os enterovírus e herpesvírus, e esta técnica tem se tornado cada vez mais aceita como referência. No entanto, mais esforços são necessários e têm sido realizados, inclusive envolvendo vários centros de pesquisa, para estabelecer técnicas de PCR e de PCR em tempo real, bem padronizadas e reprodutíveis, que possam ser efetivamente aplicadas no diagnóstico das infecções do SNC (COLIMON, 2002; JEFFERY et al., 1999). 


\section{OBJETIVOS}

\subsection{Objetivo geral}

Aplicar técnicas moleculares para a detecção de adenovírus, enterovírus e herpesvírus dos sorotipos 1 e 2 em amostras de líquor provenientes de pacientes com suspeita de infecção do SNC atendidos no Hospital Universitário da USP, como forma de diagnóstico complementar destas infecções.

\subsection{Objetivos específicos}

Aplicar a técnica de Nested-PCR, previamente padronizada no Laboratório de Biologia Molecular de Adenovírus do ICB-USP, para a detecção de adenovírus, enterovírus e herpesvírus dos sorotipos 1 e 2 em amostras de líquor.

Comparar os métodos de extração Qiaamp DNA Blood $\left(\right.$ Qiagen $^{\circledR}$ ) e MagMAX ${ }^{T M}$ Viral RNA Isolation (Ambiom) de forma a avaliar qual o mais adequado à rotina diagnóstica de um laboratório clínico.

Avaliar as características quimiocitológicas das amostras de líquor analisadas e sua correlação com os resultados obtidos através das reações moleculares.

Analisar a epidemiologia das infecções virais observadas quanto à sazonalidade, distribuição por faixa-etária e quadro clínico dos pacientes.

Padronizar reações de PCR em tempo real para a detecção de adenovírus e enterovírus, que possam, futuramente, ser aplicadas no diagnóstico complementar de rotina das infecções do SNC. 


\section{MATERIAL E MÉTODOS}

\subsection{Casuística}

Foram analisadas amostras de líquor provenientes de pacientes atendidos no Hospital Universitário da Universidade de São Paulo (HU-USP), durante o período compreendido entre agosto e novembro de 2010 e fevereiro de 2012 e janeiro de 2013. As amostras foram colhidas de acordo com a solicitação do clínico responsável pelo atendimento e submetidas às análises de rotina (quimiocitológicas e microbiológicas) no Laboratório de Análises Clínicas do HU-USP para fins de diagnóstico.

Todas as amostras relatadas como negativas para a presença de bactérias e fungos após a realização dos exames microbiológicos (microscopia e cultura) foram cedidas a esta pesquisa, sendo incluídas no estudo independentemente da idade, sexo e quadro clínico dos pacientes, totalizando 273 amostras disponíveis para análise.

Os resultados das análises quimiocitológicas e microbiológicas realizadas em cada amostra, bem como idade, sexo e quadro clínico do paciente, foram obtidos do banco de dados do HU-USP.

Esta pesquisa foi autorizada pelas comissões de ética do Instituto de Ciências Biomédicas da USP (ICB-USP) (parecer 978/CEP) e do Hospital Universitário da USP (parecer 902/09B), e relatórios parciais foram encaminhados anualmente para acompanhamento.

\subsection{Colheita e processamento das amostras}

As amostras de líquor foram colhidas de acordo com a solicitação do clínico responsável. A colheita do líquor é um procedimento de rotina em casos de suspeita de infecção ou alteração do SNC, feito pelo médico, e tem como objetivo a realização de testes diagnósticos (quimiocitológicos e microbiológicos) em busca da confirmação da suspeita inicial. Os pacientes não foram submetidos a procedimentos extras e as amostras de líquor não foram colhidas para uso exclusivo neste estudo. Após a realização dos exames de rotina pelo Laboratório de Análises Clínicas do HU-USP, uma alíquota do volume restante de cada amostra foi cedida para a realização desta pesquisa. 
As amostras de líquor foram encaminhadas ao Laboratório de Biologia Molecular de Adenovírus do ICB-USP e separadas em alíquotas de $200 \mu \mathrm{L}$, as quais foram processadas imediatamente ou armazenadas $\mathrm{a}-20^{\circ} \mathrm{C}$ até sua análise.

\subsection{Culturas celulares}

\subsubsection{Linhagens celulares utilizadas}

Durante a realização deste estudo foram cultivadas e mantidas linhagens celulares com o objetivo de produzir suspensões de protótipos virais e para a titulação viral.

Células VERO: Células da linhagem estabelecida de rim de macaco verde da espécie Cercopithecus aethiops (AMERICAN TYPE CULTURE COLLECTION - ATCC, 2013a) foram utilizadas para o cultivo de herpesvírus humanos dos sorotipos 1 e 2 .

Células HEK 293: Células da linhagem estabelecida de rim de embrião humano (ATCC, 2013b) foram utilizadas para o cultivo de adenovírus padrão do sorotipo 2.

Células GMK: Células da linhagem estabelecida de rim de macaco verde (PUBLIC HEALTH ENGLAND CULTURE COLLECTION, 2013) foram utilizadas para o cultivo de enterovírus padrão (Coxsackievírus B5).

Todas as linhagens pertencem ao acervo do Laboratório de Biologia Molecular de Adenovírus do ICB-USP e encontram-se armazenadas em estoques conservados em nitrogênio líquido.

\subsubsection{Manutenção e subcultivo das linhagens celulares}

Para a manutenção das células HEK 293, as culturas celulares foram mantidas em meio mínimo Eagle (EMEM) acrescido de 10\% de soro fetal bovino (SFB; Cultilab, Campinas, S.P., Brasil) e solução de antibióticos (penicilina 1000 UI e estreptomicina 1000 $\mu \mathrm{g} / \mathrm{mL})$ em estufa de $\mathrm{CO}_{2}(5 \%)$ a $37^{\circ} \mathrm{C}$. A cultura foi repicada duas vezes por semana, por dispersão com tripsina 0,25\% (Difco), na proporção 1:3.

No caso das células VERO e GMK, as culturas foram mantidas em meio EMEM acrescido de $10 \%$ de SFB (Cultilab) e antibióticos (penicilina 1000 UI e estreptomicina 1000 $\mu \mathrm{g} / \mathrm{mL})$ em estufa de $\mathrm{CO}_{2}(5 \%)$ a $37^{\circ} \mathrm{C}$. As culturas foram repicadas duas vezes por semana, por dispersão com tripsina 0,25\% (Difco) + EDTA (ácido etilenodiaminotetracético), na proporção 1:5. 


\subsection{Protótipos virais}

Adenovírus: Adenovírus humano do sorotipo 2 (HAdV-2, da espécie Human adenovirus ), pertencente ao acervo do Laboratório de Biologia Molecular de Adenovírus do ICB-USP, foi utilizado como protótipo nos ensaios de PCR, Nested-PCR e PCR em tempo real e para a titulação viral.

Enterovírus: Enterovírus humano do sorotipo Coxsackievirus B5 (da espécie Human enterovirus B), pertencente ao acervo do Laboratório de Biologia Molecular de Adenovírus do ICB-USP, foi utilizado como protótipo nos ensaios de PCR, Nested-PCR e PCR em tempo real e para a titulação viral.

Herpesvírus: Herpesvírus humano do sorotipo 1 (HHV-1), cedido pela Profa. Dr. Dolores Úrsula Mehnert do Laboratório de Vírus Entéricos Humanos e Animais do ICB-USP e herpersvírus humano do sorotipo 2 (HHV-2), pertencente ao acervo do Laboratório de Biologia Molecular de Adenovírus do ICB-USP, foram utilizados como protótipos nos ensaios de PCR, Nested-PCR e para a titulação viral.

\subsubsection{Cultivo dos protótipos de adenovírus, enterovírus e herpesvírus}

HAdV-2 foi cultivado em células da linhagem HEK 293. Cosxackievírus B5 foi cultivado em células GMK, e HHV-1 e HHV-2 foram cultivados em células da linhagem VERO.

Para o cultivo dos vírus padrão, culturas confluentes de cada uma das linhagens celulares foram lavadas com PBS (solução salino fosfatada) contendo $\mathrm{Ca}^{++}$e $\mathrm{Mg}^{++} \mathrm{e}$ inoculadas com 0,1 a $0,3 \mathrm{~mL}$ da suspensão de cada um dos vírus. Após uma hora de incubação a $37{ }^{\circ} \mathrm{C}$ para a adsorção viral foi acrescentado meio EMEM com $2 \%$ de SFB (Cultilab). As culturas foram incubadas a $37{ }^{\circ} \mathrm{C}$ e atmosfera de $5 \%$ de $\mathrm{CO}_{2}$ até a observação do efeito citopático (ECP), cerca de 3 a 7 dias após a inoculação (acompanhadas diariamente). Ao final do processo, os sobrenadantes das culturas contendo os vírus foram recolhidos e armazenados a $-20{ }^{\circ} \mathrm{C}$. Para o subcultivo viral, os sobrenadantes foram congelados e descongelados três vezes, e uma alíquota de $0,1 \mathrm{~mL}$ foi inoculada em nova cultura celular de forma a manter os estoques virais. 


\subsection{Titulação viral}

Os vírus padrão foram titulados por microtécnica (LENNETTE; SCHIMIDT, 1979). Suspensões virais foram diluídas na base 10. A seguir, $25 \mu \mathrm{L}$ de cada diluição foram transferidos em quadruplicata para as cavidades da microplaca. Suspensões de células GMK, VERO e HEK 293 (para HEV, HHV e HAdV, respectivamente), preparadas em meio EMEM com 10\% de SFB (Cultilab), na concentração de 200.000 células/mL, foram adicionadas às cavidades contendo suspensão viral (um tipo de vírus por placa) e em mais quatro cavidades contendo apenas meio de cultura para controle negativo. As culturas foram incubadas a $37{ }^{\circ} \mathrm{C}$ com atmosfera de $5 \%$ de $\mathrm{CO}_{2}$. A leitura foi realizada diariamente, ao microscópio ótico, com observação do ECP até a definição do título (máximo 7 dias). O título viral foi determinado em doses infectantes de cultura de tecido $50 \%$ ( DICT $\left._{50}\right)$, utilizando-se o método de Reed e Muench (LENNETTE; SCHIMIDT, 1979).

\subsection{Extração dos ácidos nucleicos}

Para a extração dos ácidos nucleicos virais, tanto DNA quanto RNA, das amostras clínicas e padrões (controles positivos), foram utilizados os métodos Qiaamp DNA Blood (Qiagen $^{\circledR}$, Valência, Califórnia, EUA) e MagMAX ${ }^{T M}$ Viral RNA Isolation (Ambiom, Foster City, Califórnia, EUA) em extrator automático MagMAX ${ }^{\mathrm{TM}}$ Express (Applied Biosystems, Foster City, Califórnia, EUA), ambos disponíveis comercialmente e segundo instruções do fabricante.

Para a extração das amostras de líquor através do método Qiaamp DNA Blood $\left(\right.$ Qiagen $^{\circledR}$ ), $20 \mu \mathrm{L}$ da protease fornecida pelo fabricante foram adicionados a um microtubo, ao qual foram acrescidos, em seguida, $200 \mu \mathrm{L}$ da amostra de líquor e $200 \mu \mathrm{L}$ do tampão de lise (Buffer $A L$ ). A mistura foi homogeneizada em vórtex por 15 segundos e incubada em banho seco a $56^{\circ} \mathrm{C}$ por 10 minutos. Uma breve centrifugação foi realizada a seguir para eliminar gotas do interior da tampa do tubo. Em seguida, foram adicionados $200 \mu \mathrm{L}$ de etanol absoluto $\left(\right.$ Merck $^{\circledR}$; Merck S.A., Rio de Janeiro, R.J., Brasil) e o tubo submetido à homogeneização por vórtex durante 15 segundos e breve centrifugação para eliminação de gotas na tampa do microtubo. A mistura obtida foi transferida para uma coluna contendo membrana de sílicagel, e submetida à centrifugação a $6000 \mathrm{x} g$ a $25^{\circ} \mathrm{C}$ por 1 minuto. $\mathrm{O}$ filtrado foi descartado e a coluna transferida para novo tubo de coleta, acrescida de $500 \mu \mathrm{L}$ de tampão de lavagem (AW1) e submetida à centrifugação a $6000 \mathrm{x} g$ a $25^{\circ} \mathrm{C}$ por 1 minuto. $\mathrm{O}$ filtrado foi mais uma 
vez descartado, e a coluna transferida para novo tubo de coleta. Foram adicionados, então, $500 \mu \mathrm{L}$ de tampão de lavagem (AW2), e procedida a centrifugação a 12000 x $g$ a $25^{\circ} \mathrm{C}$ por 3 minutos. O filtrado foi descartado e a centrifugação repetida para a eliminação de qualquer resíduo de tampão.

Ao final, foram adicionados $200 \mu \mathrm{L}$ de tampão de eluição (AE) no centro da coluna de sílica, sem tocar à membrana. Após incubação por 5 minutos a $25^{\circ} \mathrm{C}$ o material foi submetido à centrifugação 6000 x $g$ a $25^{\circ} \mathrm{C}$ por 1 minuto. O filtrado obtido foi transferido para um microtubo de 1,5 mL e utilizado, em seguida, para a síntese de cDNA. O restante foi armazenado a $-80^{\circ} \mathrm{C}$.

Para a extração das amostras de líquor pelo método MagMAX ${ }^{T M}$ Viral RNA Isolation (Ambiom), algumas soluções foram preparadas a partir dos reagentes fornecidos pelo fabricante: Bead mix solution, contendo $10 \mu \mathrm{L}$ do RNA binding beads e $10 \mu \mathrm{L}$ do Lysis binding enhancer por reação; Lysis binding solution, contendo $65 \mu \mathrm{L}$ de Lysis binding concentrado, $1 \mu \mathrm{L}$ de carreador de RNA e $65 \mu \mathrm{L}$ de isopropanol 100\% (Merck ${ }^{\circledR}$ ) por reação.

Os reagentes e amostras foram dispostos em placa de 96 orifícios fornecida pelo fabricante de acordo com as orientações do método (Quadro 3).

Quadro 3 - Disposição dos reagentes e amostras na placa para extração dos ácidos nucleicos- MagMAX ${ }^{T M}$ Viral RNA Isolation (Ambiom).

\begin{tabular}{||l|c|c|c||}
\hline \multirow{2}{*}{ Posição na placa } & Reagentes & Volume \\
\hline \multirow{2}{*}{ A } & \multirow{2}{*}{ Lise/ ligação } & Bead mix solution & $20 \mu \mathrm{L}$ \\
\cline { 3 - 4 } & & Amostra & $50 \mu \mathrm{L}$ \\
\cline { 3 - 4 } & & Lysis biding solution & $130 \mu \mathrm{L}$ \\
\hline B & Lavagem & Tampão de lavagem 1 & $150 \mu \mathrm{L}$ \\
\hline C & Lavagem & Tampão de lavagem 1 & $150 \mu \mathrm{L}$ \\
\hline D & Lavagem & Tampão de lavagem 2 & $150 \mu \mathrm{L}$ \\
\hline E & Lavagem & Tampão de lavagem 2 & $150 \mu \mathrm{L}$ \\
\hline F & Eluição & Tampão de eluição & $90 \mu \mathrm{L}$ \\
\hline
\end{tabular}

A seguir, a placa contendo reagentes e amostras, foi colocada em equipamento para extração automática MagMAX ${ }^{\mathrm{TM}}$ Express (Applied Biosystems ${ }^{\circledR}$, Foster City, Califórnia, EUA). Após finalização das etapas de extração, o material contido na fileira $F$ da placa, no qual se encontravam o RNA e DNA extraídos, foi transferido para um microtubo de $1,5 \mathrm{~mL}$ e usado imediatamente para a síntese de cDNA. O restante foi armazenado a $-80{ }^{\circ} \mathrm{C}$. 


\subsection{Comparação dos métodos de extração dos ácidos nucleicos}

Para a comparação dos métodos de extração Qiaamp DNA Blood (Qiagen ${ }^{\circledR}$ ) e MagMAX ${ }^{T M}$ Viral RNA Isolation (Ambiom), foram realizadas análises estatísticas de acordo com descrito por Gordis (2004). Cento e quatro amostras foram extraídas por ambos os métodos acima citados em intervalo não superior a uma semana. Os produtos destas extrações foram submetidos às técnicas de PCR e Nested-PCR e os resultados comparados. Nesta comparação, o método MagMAX ${ }^{T M}$ Viral RNA Isolation (Ambiom) foi considerado como sendo de referência. Foram calculadas a sensibilidade (habilidade do método em identificar corretamente as amostras positivas), a especificidade (habilidade de identificar corretamente as amostras negativas), o valor preditivo positivo (VPP; probabilidade de uma amostras com teste positivo realmente conter o vírus) e o valor preditivo negativo (VPN; probabilidade de uma amostra com teste negativo realmente não conter o vírus).

O quadro 4 apresenta a forma de tabulação dos dados utilizados para os cálculos estatísticos.

Quadro 4 - Esquema de tabulação dos resultados para a comparação de sensibilidade, especificidade, VPP e VPN entre os métodos utilizados para a extração de ácidos nucleicos.

\begin{tabular}{||c|c|c|c||}
\hline Referência/ Teste & Positivo & Negativo & Total \\
\hline Positivo & $\begin{array}{c}\text { A: Número de amostras } \\
\text { positivas verdadeiras }\end{array}$ & $\begin{array}{c}\text { B: Número de amostras } \\
\text { falsas positivas }\end{array}$ & $\begin{array}{c}\text { A+B: Total de amostras } \\
\text { positivas detectadas pelo } \\
\text { teste }\end{array}$ \\
\hline Negativo & $\begin{array}{c}\text { C: } \text { Número de amostras } \\
\text { falsas negativas }\end{array}$ & $\begin{array}{c}\text { D: } \text { Número de amostras } \\
\text { verdadeiras negativas }\end{array}$ & $\begin{array}{c}\text { C+D: } \text { Total de amostras } \\
\text { negativas detectadas pelo } \\
\text { teste }\end{array}$ \\
\hline Total & $\begin{array}{c}\text { A+C: } \text { Total de amostras } \\
\text { positivas verdadeiras }\end{array}$ & $\begin{array}{c}\text { B+D: } \text { Total de amostras } \\
\text { negativas verdadeiras }\end{array}$ & $\begin{array}{c}\text { N: Total de amostras } \\
\text { analisadas }\end{array}$ \\
\hline
\end{tabular}

Fonte: Gordis, 2004. 
Para a realização dos cálculos a partir dos dados tabulados foram utilizadas as seguintes equações:

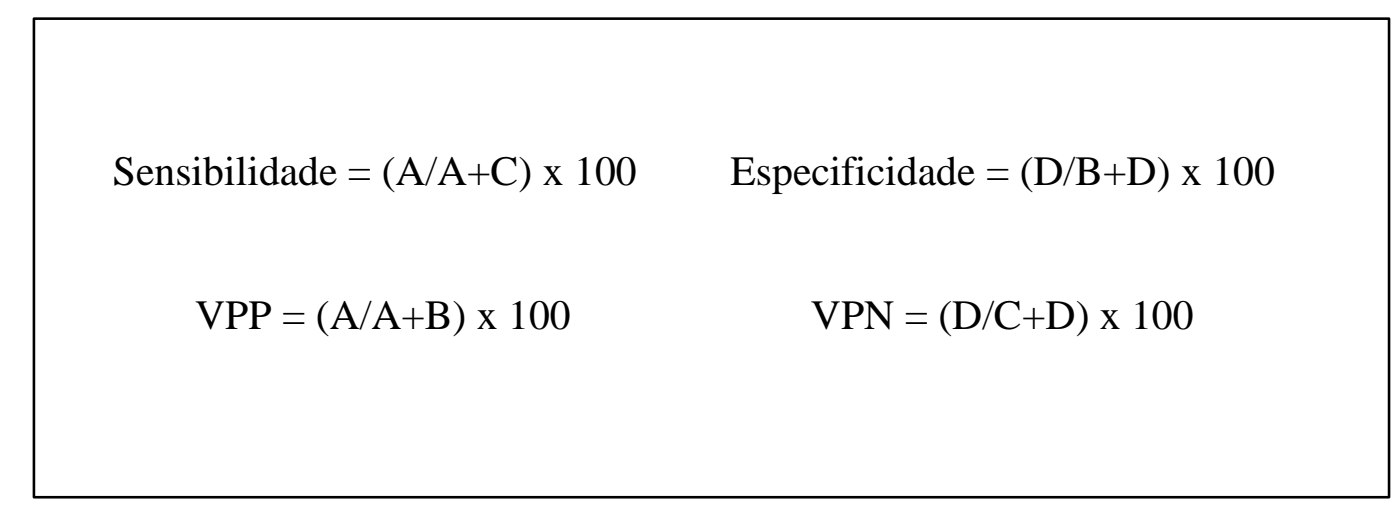

A intensidade da concordância entre os métodos de extração foi determinada através do índice Kappa, no qual são considerados os resultados concordantes observados e excluídos os resultados concordantes ao acaso.

Para o cálculo do índice de Kappa, utilizou-se a fórmula:

$$
\kappa=-\frac{\mathrm{po}-\mathrm{pa}}{1-\mathrm{pa}}
$$

onde :

$$
\text { po }=\frac{\mathrm{A}+\mathrm{D}}{\mathrm{N}}(\text { proporção observada de concordância })
$$

pa $=[(\mathrm{A}+\mathrm{B}) \mathrm{x}(\mathrm{A}+\mathrm{C})]+[(\mathrm{C}+\mathrm{D}) \mathrm{x}(\mathrm{B}+\mathrm{D})]$ (proporção esperada de concordância pelo acaso) $\mathrm{N}^{2}$ 
O valor de $\kappa$ situa-se entre -1 e 1 , sendo:

$\kappa<0 \quad$ concordância menor que a obtida ao acaso

$\kappa=0 \quad$ concordância igual à obtida ao acaso

$\kappa>0 \quad$ concordância maior que a obtida ao acaso

$\kappa=1 \quad$ concordância perfeita

São sugeridos os seguintes níveis quantitativos de significância para o valor de $\kappa$ :

$\kappa<0 \quad$ concordância pobre

$\kappa$ de $0,01-0,20 \quad$ concordância fraca

К de $0,21-0,40 \quad$ concordância regular

$\kappa$ de $0,41-0,60 \quad$ concordância moderada

К de $0,61-0,80 \quad$ concordância substancial

$\kappa$ de $0,81-1,00 \quad$ concordância quase perfeita

\subsection{Transcrição reversa do genoma dos enterovírus}

Para a síntese do cDNA a partir do genoma dos HEV, foi preparada uma mistura de reagentes contendo $50 \mu \mathrm{M}$ de Randon primer (Applied Biosystems ${ }^{\circledR}$ ), $10 \mathrm{mM}$ de mistura de dNTP's (Fermentas), e $10 \mu \mathrm{L}$ do produto de extração em volume final de $20 \mu \mathrm{L}$. Esta mistura foi incubada por 10 minutos a $65^{\circ} \mathrm{C}$ e, em seguida, acrescida de nova mistura contendo $100 \mathrm{U}$ da enzima Transcriptase Reversa MMLV (Invitrogen ${ }^{\mathrm{TM}}$ ), $6 \mu \mathrm{L}$ de tampão RT (Invitrogen ${ }^{\mathrm{TM}}$ ) e $0,1 \mathrm{M}$ de DTT ( Invitrogen $^{\mathrm{TM}}$ ), em volume final de $10 \mu \mathrm{L}$. A mistura resultante foi incubada a $25{ }^{\circ} \mathrm{C}$ por 10 minutos, $37{ }^{\circ} \mathrm{C}$ por 50 minutos e $70{ }^{\circ} \mathrm{C}$ por 15 minutos para a obtenção do cDNA viral.

\subsection{Oligonucleotídeos}

Para as reações de PCR e Nested-PCR, foram utilizados primers direcionados para as seguintes regiões dos vírus: região do gene Hexon dos HAdV; região 5'-NTR dos HEV e DNA polimerase dos HHV- 1 e 2 (neste último caso, a reação molecular possibilita a detecção 
de ambos os sorotipos de herpesvírus, mas não permite diferenciá-los). As sequências dos oligonucleotídeos são mostradas no quadro 5.

Quadro 5 - Sequências dos oligonucleotídeos utilizados nas reações de PCR e Nested-PCR para a detecção de HAdV, HEV e HHV-1 e 2.

\begin{tabular}{|c|c|c|c|c|}
\hline Vírus & Oligonucleotídeos & Sequências & Produto & Referências \\
\hline HEV & $\begin{array}{l}\text { EV sense } \\
\text { EV anti-sense }\end{array}$ & $\begin{array}{l}\text { 5'-CGGTACCTTTGTRCGCCTGTTTTA-3', } \\
\text { 5'-GAAACACGGACACCCAAAGTAGTCG-3' }\end{array}$ & $498 \mathrm{pb}$ & $\begin{array}{c}\text { Casas et al., } \\
1997 .\end{array}$ \\
\hline $\begin{array}{l}\text { região } \\
5 \text { ”NTR }\end{array}$ & $\begin{array}{l}\text { EV sense nested } \\
\text { EV anti-sense nested }\end{array}$ & $\begin{array}{l}\text { 5'-CAAGCACTTCTGTTTCCCCG-3' } \\
\text { 5'-GGATTAGCCGCATTCAGGG-3' }\end{array}$ & $308 \mathrm{pb}$ & $\begin{array}{c}\text { Casas et al., } \\
1997 .\end{array}$ \\
\hline HHV-1 e 2 & $\begin{array}{l}\text { HHV geral sense } \\
\text { HHV geral anti-sense }\end{array}$ & $\begin{array}{l}\text { 5'-GTGKTBGACTTTGCCAGCCTSTAYCC-3' } \\
\text { 5'-GTCCGTGTCCCCGTAGATGAYBCG-3' }\end{array}$ & $597 \mathrm{pb}$ & Santos, 2009. \\
\hline $\begin{array}{c}\text { gene DNA } \\
\text { pol. }\end{array}$ & HHV semi-nested & 5'-GGCCGCCATCAAGGTSGTGTG-3' & $248 \mathrm{pb}$ & Santos, 2009. \\
\hline HAdV & $\begin{array}{l}\text { Adhex F1 } \\
\text { Adhex R1 }\end{array}$ & $\begin{array}{l}\text { 5'- TICTTTGACATICGIGGIGTICTIGA-3' } \\
\text { 5'- CGTTCICIGCCTGRTTCCACA-3' }\end{array}$ & $900 \mathrm{pb}$ & $\begin{array}{l}\text { Crawford- } \\
\text { Miksza and } \\
\text { Schnurr, } 1996\end{array}$ \\
\hline gene hexon & $\begin{array}{l}\text { Adhex F2 } \\
\text { Adhex R2 }\end{array}$ & $\begin{array}{l}\text { 5'-GGYCCYAGYTTYAARCCCTAYTC-3' } \\
\text { 5'-GGTTCTGTCICCCAGAGARTCIAGCA-3' }\end{array}$ & $825 \mathrm{pb}$ & $\begin{array}{c}\text { Lu e Erdman, } \\
2006\end{array}$ \\
\hline
\end{tabular}

Gene DNA pol: Gene da DNA polimerase dos herpesvírus.

Bases degeneradas: $R(A+G) ; K(G+T) ; B(C+G+T) ; Y(C+T) ; S(G+C)$.

Bases alternativas: $\mathrm{I}$ (desoxiinosina). 
As temperaturas de anelamento dos oligonucleotídeos utilizados são mostradas a seguir (Quadro 6).

Quadro 6 - Temperaturas de anelamento dos oligonucleotídeos utilizados nas reações de PCR e Nested-PCR.

\begin{tabular}{|c|c|c|}
\hline \multirow{2}{*}{ Oligonucleotídeo } & \multicolumn{2}{|c|}{ Temperatura de anelamento } \\
\cline { 2 - 3 } & PCR & Nested-PCR \\
\hline HAdV & $45^{\circ} \mathrm{C}$ & $50^{\circ} \mathrm{C}$ \\
\hline HHV-1 e HHV-2 & $56^{\circ} \mathrm{C}$ & $67^{\circ} \mathrm{C}$ \\
\hline HEV & $55^{\circ} \mathrm{C}$ & $63^{\circ} \mathrm{C}$ \\
\hline
\end{tabular}

\subsection{Reações de PCR e Nested-PCR}

\subsubsection{Herpesvírus e enterovírus}

Nas reações de PCR para a detecção de HEV e HHV-1 e 2 foram preparadas misturas de reagentes contendo $1 \mathrm{U}$ da enzima DNA polimerase Thermus thermophilus (Tth; Biotools ${ }^{\circledR}$; Biotools BeM Labs, S.A., Madrid, Espanha), 1X Tampão de enzima (Biotools ${ }^{\circledR}$ ), $10 \mathrm{nM}$ de mistura de dNTP's (Fermentas), 5 pmol de cada oligonucleotídeo específico (quadro 5) e $10 \mu \mathrm{L}$ do DNA ou cDNA extraídos, em volume final de $50 \mu \mathrm{L}$.

Para as reações de Nested-PCR, foram preparadas misturas de reagentes contendo $1 \mathrm{U}$ da enzima DNA polimerase Thermus thermophilus (Biotools ${ }^{\circledR}$ ), 1X Tampão de enzima (Biotools $^{\circledR}$ ), $10 \mathrm{mM}$ de mistura de dNTP's (Fermentas), 10 pmol de cada oligonucleotídeo específico (quadro 5) e $10 \mu \mathrm{L}$ do produto de PCR, em volume final de $50 \mu \mathrm{L}$.

Tanto as reações de PCR quanto Nested-PCR foram submetidas ao seguinte programa em termociclador Mastercycler Gradiente (Eppendorf ${ }^{\circledR}$ ): $94{ }^{\circ} \mathrm{C}$ por 5 minutos, seguido de 40 ciclos de $94{ }^{\circ} \mathrm{C}$ por 30 segundos, temperatura de anelamento de cada primer (para reação de PCR ou Nested-PCR de acordo com o quadro 6) por 30 segundos e $72{ }^{\circ} \mathrm{C}$ por 30 segundos. Após o último ciclo, as reações foram incubadas a $72{ }^{\circ} \mathrm{C}$ por 5 minutos para completa extensão dos produtos amplificados (SANTOS, 2009). 


\subsubsection{Adenovírus}

No caso dos HAdV, para a reação de PCR, foi preparada uma mistura de reagentes contendo $1 \mathrm{U}$ da enzima DNA polimerase Thermus thermophilus (Biotools ${ }^{\circledR}$ ), 1X Tampão de enzima (Biotools ${ }^{\circledR}$ ), $10 \mathrm{mM}$ de mistura de dNTP's (Fermentas), 10 pmol de cada oligonucleotídeo específico (quadro 5) e $10 \mu \mathrm{L}$ do DNA extraído, em volume final de $50 \mu \mathrm{L}$.

Para a reação de Nested-PCR, foi preparada uma mistura de reagentes contendo $1 \mathrm{U}$ da enzima DNA polimerase Thermus thermophilus (Biotools ${ }^{\circledR}$ ), $1 \mathrm{X}$ Tampão de enzima (Biotools ${ }^{\circledR}$ ), $10 \mathrm{mM}$ de mistura de dNTP's (Fermentas), 10 pmol de cada oligonucleotídeo específico (quadro 5) e $10 \mu \mathrm{L}$ do produto de PCR, em volume final de $50 \mu \mathrm{L}$.

Ambas as reações foram submetidas ao seguinte programa em termociclador Mastercycler Gradiente (Eppendorf ${ }^{\circledR}$ ): $94{ }^{\circ} \mathrm{C}$ por 2 minutos, seguido de 35 ciclos de $94{ }^{\circ} \mathrm{C}$ por 1 minuto, temperatura de anelamento de cada primer (para reação de PCR ou Nested-PCR de acordo com o quadro 6) por 1 minuto e $72{ }^{\circ} \mathrm{C}$ por 1 minuto. Após o último ciclo, as reações foram incubadas a $72{ }^{\circ} \mathrm{C}$ por 5 minutos para completa extensão dos produtos amplificados.

\subsubsection{Observação dos produtos amplificados}

Os produtos amplificados foram submetidos à eletroforese em gel de agarose (Invitrogen ${ }^{\mathrm{TM}}$ ) a 1,5\% em tampão Tris acetato 0,5X (TAE; $40 \mathrm{mM}$ Tris-acetato, ácido acético $20 \mathrm{mM}$, EDTA 0,5 M pH 8,0), contendo $4 \mathrm{~mL}$ de solução de brometo de etídeo a $5 \mathrm{mg} / \mathrm{mL}$ (Invitrogen ${ }^{\mathrm{TM}}$ ). A corrida eletroforética foi realizada em cuba de eletroforese horizontal, contendo tampão TAE $0,5 \mathrm{X}$, sob tensão de 100 V. Após cerca de uma hora de corrida, a presença dos fragmentos no gel foi evidenciada pela exposição à luz UV, e o gel documentado em fotografias digitais utilizando-se o fotodocumentador MultiDoc- $I^{\mathrm{TM}}$ Imaging System (UVP).

\subsection{Reação de PCR em tempo real}

Reações de PCR em tempo real foram padronizadas para a detecção de HAdV e HEV. Diluições seriadas na base $10\left(10^{-1}\right.$ a $\left.10^{-10}\right)$ de vírus padrão (HAdV-2 e Coxsackievírus B5) foram utilizadas neste processo, assim como algumas amostras de líquor consideradas positivas para os vírus estudados (detectadas através da Nested-PCR). 
As diluições de vírus padrão foram, simultaneamente, submetidas tanto à Nested-PCR quanto à PCR em tempo real, fornecendo um parâmetro inicial para comparação, indicativo da relação de sensibilidade entre as técnicas. O número de amostras de LCR testadas pela PCR em tempo real foi muito pequeno, por motivos de pouco volume de amostra e/ou degradação do material extraído, impedindo a realização de análises estatísticas para a comparação.

\subsubsection{Oligonucleotídeos}

Para a detecção dos HAdV foram selecionados primers e sonda direcionados à região do gene Hexon (JOTHIKUMAR et al., 2005). Para a detecção de HEV, foram selecionados primers e sonda direcionados à região 5'-NTR (VERSTREPEN; BRUYNSEELS; MERTENS, 2002).

Os oligonucleotídeos mencionados acima são descritos no quadro a seguir (Quadro 7).

Quadro 7 - Conjuntos de sondas e primers utilizados para a detecção de adenovírus e enterovírus através da reação de PCR em tempo real.

\begin{tabular}{|c|c|c|c|}
\hline Vírus & Oligonucleotídeos & Sequências & Referências \\
\hline \multirow{3}{*}{ HAdV } & HAdV sense & 5'-GGACGCCTCGGAGTACCTGAG-3' & \multirow{3}{*}{$\begin{array}{c}\text { JOTHIKUMAR et } \\
\text { al., } 2005 .\end{array}$} \\
\hline & HAdV anti-sense & 5'-ACIGTGGGGTTTCTGAACTTGTT-3' & \\
\hline & $\begin{array}{l}\text { HAdV Sonda } \\
\text { TaqMan }\end{array}$ & $\begin{array}{c}\text { 5'-/56-FAM/ } \\
\text { CTGGTGCAG/ZEN/TTCGCCCGTGCCA } \\
\text { /3IABkFQ/-3' }\end{array}$ & \\
\hline \multirow{3}{*}{ HEV } & HEV sense & 5'-CCCTGAATGCGGCTAATCC-3' & \multirow{3}{*}{$\begin{array}{l}\text { VERSTREPEN; } \\
\text { BRUYNSEELS; } \\
\text { MERTENS, } 2002 .\end{array}$} \\
\hline & HEV anti-sense & 5'-ATTGTCACCATAAGCAGCCA-3' & \\
\hline & HEV Sonda TaqMan & $\begin{array}{l}\text { 5'-/56-FAM/AACCGACTA/ZEN/ } \\
\text { CTTTGGGTGTCCGTGTTTC/3IABkFQ/-3, }\end{array}$ & \\
\hline
\end{tabular}




\subsubsection{Adenovírus}

Para a elaboração da curva de calibração da PCR em tempo real para a detecção de adenovírus, o DNA viral extraído de HAdV-2 foi diluído na base $10\left(10^{-1}\right.$ a $\left.10^{-10}\right)$ em água ultrapura. Foi utilizado, nesta reação, o kit QuantiFast Probe PCR + ROX Vial Kit (Qiagen ${ }^{\circledR}$, Valência, Califórnia, EUA) cujo Master mix contém a enzima DNA polimerase HotStarTaq Plus, tampão de reação QuantiFast PCR Buffer, e mistura de dNTP's (dATP, dCTP, dGTP e dTTP). A $12,5 \mu \mathrm{L}$ do Master mix fornecido pelo fabricante, foram adicionados $1 \mu \mathrm{L}$ da mistura de sonda TaqMan ${ }^{\circledR}$ e primers (contendo 5 pmol de cada primer e 2,5 pmol da sonda), $5 \mu \mathrm{L}$ do DNA viral extraído e água ultrapura para completar o volume final de $25 \mu \mathrm{L}$ de reação.

A reação ocorreu em termociclador Corbett Rotorgene 6000 (Corbett Research) obedecendo ao seguinte ciclo: $95{ }^{\circ} \mathrm{C}$ por 15 minutos, seguidos de 45 ciclos de $95{ }^{\circ} \mathrm{C}$ por 10 segundos, $55{ }^{\circ} \mathrm{C}$ por 30 segundos e $72{ }^{\circ} \mathrm{C}$ por 15 segundos. Os resultados da amplificação foram analisados pelo software Rotor-Gene 1.7.40.

\subsubsection{Enterovírus}

Para a elaboração da curva de calibração da PCR em tempo real para a detecção de enterovírus, o cDNA viral obtido após transcrição reversa do RNA extraído a partir de Cosxackievírus B5 foi diluído na base $10\left(10^{-1}\right.$ a $\left.10^{-10}\right)$ em água ultrapura. Foi utilizado, nesta reação, o kit QuantiFast Probe PCR + ROX Vial Kit (Qiagen $\left.{ }^{\circledR}\right)$, cujo Master mix contém a enzima DNA polimerase HotStarTaq Plus, tampão de reação QuantiFast PCR Buffer, e mistura de dNTP's (dATP, dCTP, dGTP e dTTP). A 12,5 $\mu \mathrm{L}$ do Master mix fornecido pelo fabricante, foram adicionados $1 \mu \mathrm{L}$ da mistura de sonda TaqMan ${ }^{\circledR}$ e primers (contendo 10 pmol de cada primer e 5 pmol da sonda), $5 \mu \mathrm{L}$ do cDNA viral e água ultrapura para completar o volume final de $25 \mu \mathrm{L}$ de reação.

A reação ocorreu em termociclador Corbett Rotorgene 6000 (Corbett Research) obedecendo ao seguinte ciclo: $95{ }^{\circ} \mathrm{C}$ por 10 minutos, seguidos de 45 ciclos de $95{ }^{\circ} \mathrm{C}$ por 15 segundos e $60{ }^{\circ} \mathrm{C}$ por 1 minuto (anelamento e extensão combinados). Os resultados da amplificação foram analisados pelo software Rotor-Gene 1.7.40. 


\section{RESULTADOS}

\subsection{Cultivo dos protótipos de adenovírus, enterovírus e herpesvírus}

Células da linhagem HEK 293 (rim de embrião humano) foram utilizadas para o cultivo de adenovírus padrão do sorotipo 2 (Figura 9 A). Após 6 dias da inoculação do vírus nas culturas celulares foi observado o efeito citopático caracterizado por lise celular e formação de agrupamentos de células semelhantes a "cachos de uva" (Figura 9 B).

Figura 9 - Aspecto de células HEK 293 em cultura antes e após a inoculação de HAdV-2 padrão.
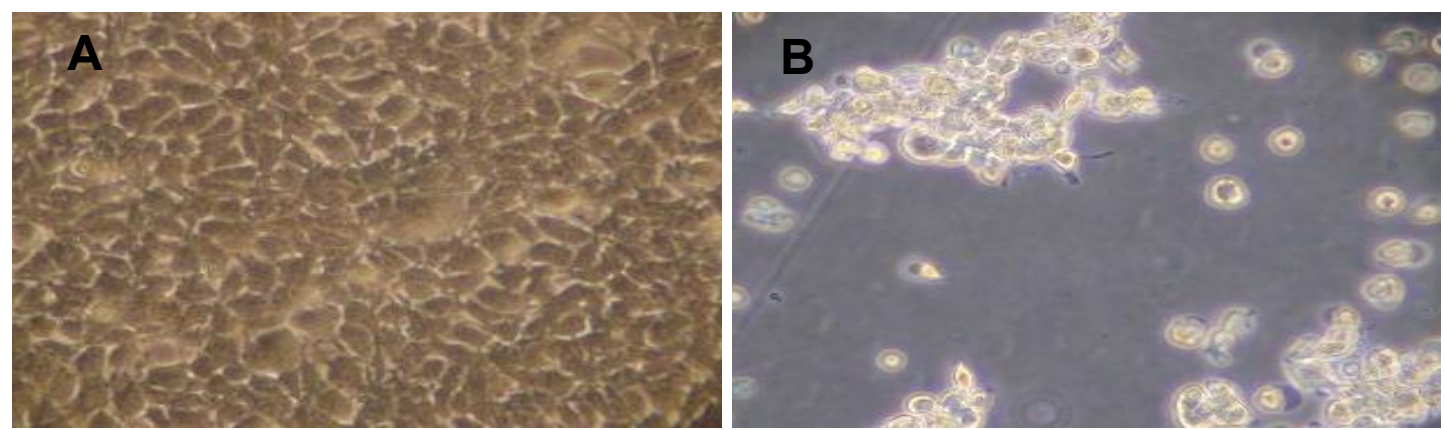

A: Cultura de células HEK 293 não inoculadas. B: Efeito citopático causado por HAdV-2 após 6 dias da inoculação. Registro digital de microscopia óptica com aumento de 300x.

Enterovírus padrão do sorotipo Coxsackievírus B5 foi inoculado em células da linhagem GMK (rim de macaco verde) (Figura 10 A). Após 4 dias da inoculação do vírus foi observado efeito citopático característico, com picnose nuclear, arredondamento, degeneração e lise celular (Figura $10 \mathrm{~B}$ ).

Figura 10 - Aspecto de células GMK em cultura antes e após a inoculação com Coxsackievírus B5 padrão.
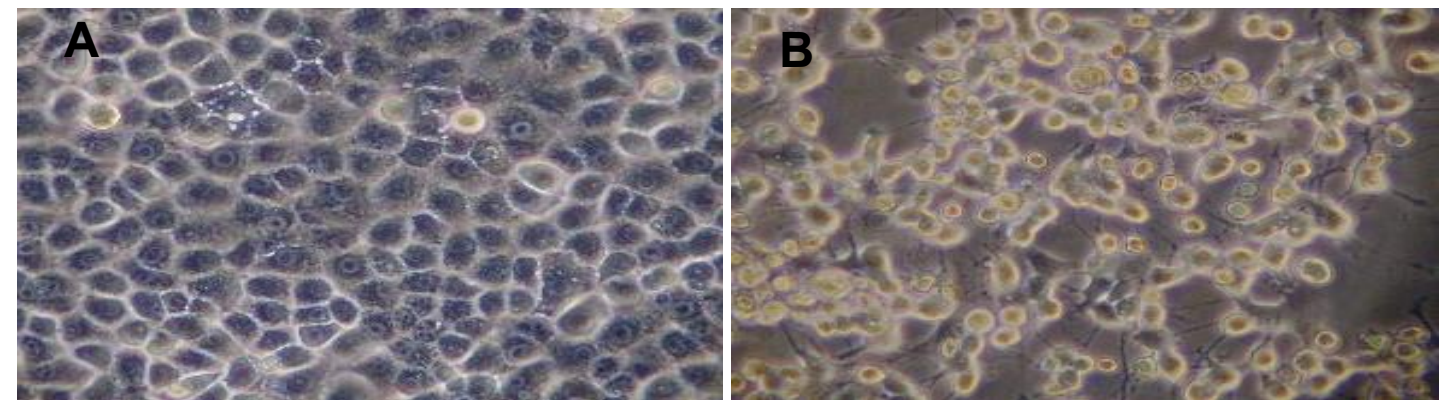

A: Cultura de células GMK não inoculadas. B: Efeito citopático causado por Coxsackievírus B5 após 4 dias da inoculação. Registro digital de microscopia óptica com aumento de 300x. 
Foram cultivados herpesvírus padrão do sorotipo 1 em células da linhagem VERO (rim de macaco verde) (Figura 11 A). Após 6 a 7 dias da inoculação do vírus foi observado o efeito citopático característico, com degeneração celular e formação de sincícios. (Figuras 11 $\mathrm{B}, \mathrm{C}$ e D).

Figura 11 - Aspecto de células VERO em cultura antes e após inoculação com HHV-1 padrão.

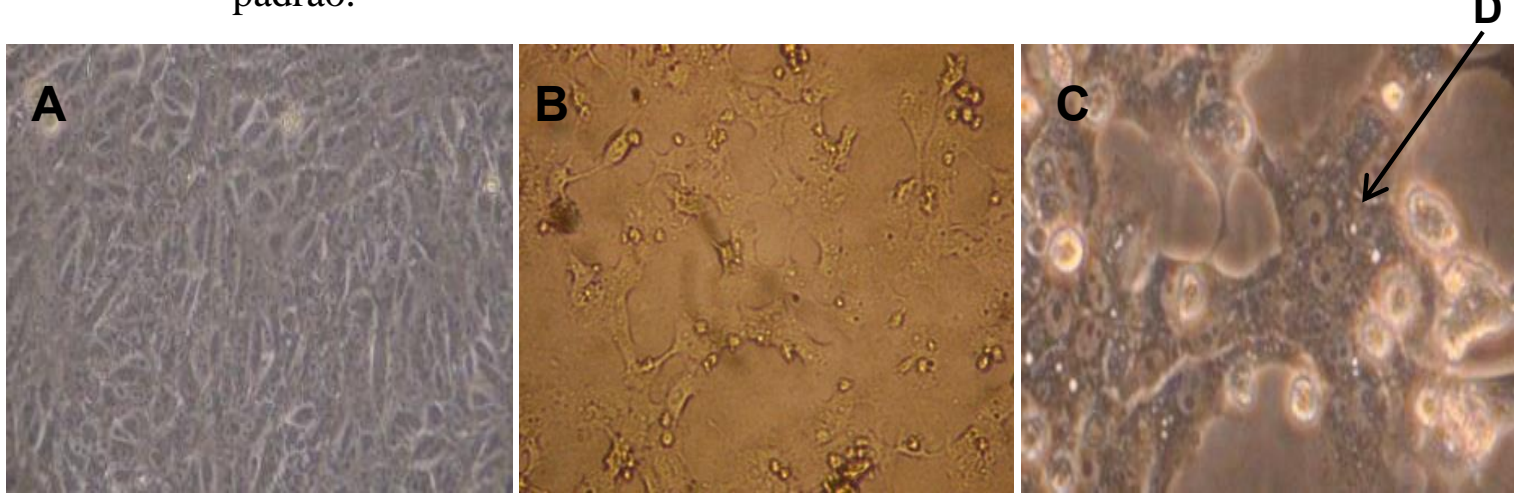

A: Cultura de células VERO não inoculadas. B e C: Efeito citopático causado por HHV-1 após 6 a 7 dias da inoculação. D: Destaque para a formação de sincícios. Registro digital de microscopia óptica com aumento de 300x (A e B) e 600x (C).

\subsection{Titulação dos vírus padrão}

Após 7 dias da inoculação de culturas celulares da linhagem HEK 293 com HAdV-2 padrão, foi observado o efeito citopático. O título obtido, calculado pelo método de Reed e Muench, foi de $10^{3} \mathrm{DICT}_{50} / 25 \mu \mathrm{L}$ da suspensão viral.

Com relação aos HEV, após 7 dias da inoculação de culturas celulares da linhagem GMK com HEV padrão (Coxsackievírus B5), foi observado o efeito citopático. O título obtido, calculado pelo método de Reed e Muench, foi de $10^{6,5} \mathrm{DICT}_{50} / 25 \mu \mathrm{L}$ da suspensão viral.

Nas culturas celulares da linhagem VERO, inoculadas com diluições do vírus padrão HHV-1, foi observado o efeito citopático após 7 dias. O título obtido neste caso, calculado pelo método de Reed e Muench, foi de $10^{4,8} \mathrm{DICT}_{50} / 25 \mu \mathrm{L}$ da suspensão viral.

\subsection{Avaliação dos protocolos utilizados para a extração do DNA e RNA viral}

As 104 amostras de líquor cujos ácidos nucleicos foram extraídos através de ambos os protocolos, MagMAX ${ }^{T M}$ Viral RNA Isolation (Ambiom) e Qiaamp DNA Blood (Qiagen ${ }^{\circledR}$ ), foram submetidas às reações de PCR e Nested-PCR para a detecção de HAdV, HEV e HHV- 
1/HHV-2. A detecção de qualquer um dos vírus citados caracterizou uma extração positiva. Os resultados foram analisados e estão tabulados abaixo (Tabela 2):

Tabela 2 - Resultados obtidos após extração dos ácidos nucleicos presentes nas amostras de líquor, seguida das reações de PCR e Nested-PCR para a detecção de HAdV, HEV e HHV-1/HHV-2. Comparação dos métodos de extração.

\begin{tabular}{ccccc}
\hline \hline & $\operatorname{MagMAX}^{T M}(\mathbf{A})$ & & \\
\hline & Positivas & Negativas & Total \\
\hline Qiaamp $(\mathbf{B})$ & Positivas & 6 & 2 & 8 \\
\hline & Negativas & 5 & 91 & 96 \\
\hline Total & & 11 & 93 & 104 \\
\hline \hline
\end{tabular}

Métodos de extração utilizados: A: MagMAX ${ }^{T M}$ Viral RNA Isolation (Ambiom). B: Qiaamp DNA Blood (Qiagen $\left.{ }^{\circledR}\right)$.

Em relação ao MagMAX ${ }^{T M}$ Viral RNA Isolation (Ambiom), o protocolo Qiaamp DNA Blood $\left(\right.$ Qiagen $^{\circledR}$ ) apresentou sensibilidade de $54 \%$ e especificidade de 97,8\% (capacidade de detectar amostras realmente positivas e negativas, respectivamente).

Em relação ao valor preditivo positivo, $75 \%$ das amostras positivas detectadas pelo protocolo Qiaamp DNA Blood $\left(\right.$ Qiagen $^{\circledR}$ ) tendem a ser realmente positivas. Considerando-se o valor preditivo negativo do teste, $94,7 \%$ das amostras determinadas como negativas pelo Qiaamp DNA Blood $\left(\right.$ Qiagen $\left.^{\circledR}\right)$ tendem a ser realmente negativas.

O índice de concordância simples observado entre os protocolos de extração foi de 93\%. O índice Kappa, que considera tanto a concordância simples observada quanto os resultados obtidos ao acaso foi de 0,6 , considerado intermediário ou razoável.

\subsection{Reações de PCR e Nested-PCR}

A seguir são apresentadas as fotos dos géis que mostram os produtos amplificados obtidos após as reações de PCR (Figura 12) e Nested-PCR (Figura 13) para a detecção de HAdV, HEV e HHV-1/HHV-2 (todos vírus padrão). 
Figura 12 - Perfil eletroforético dos produtos amplificados de HAdV, HEV e HHV-1/ HHV-2 após a reação de PCR.

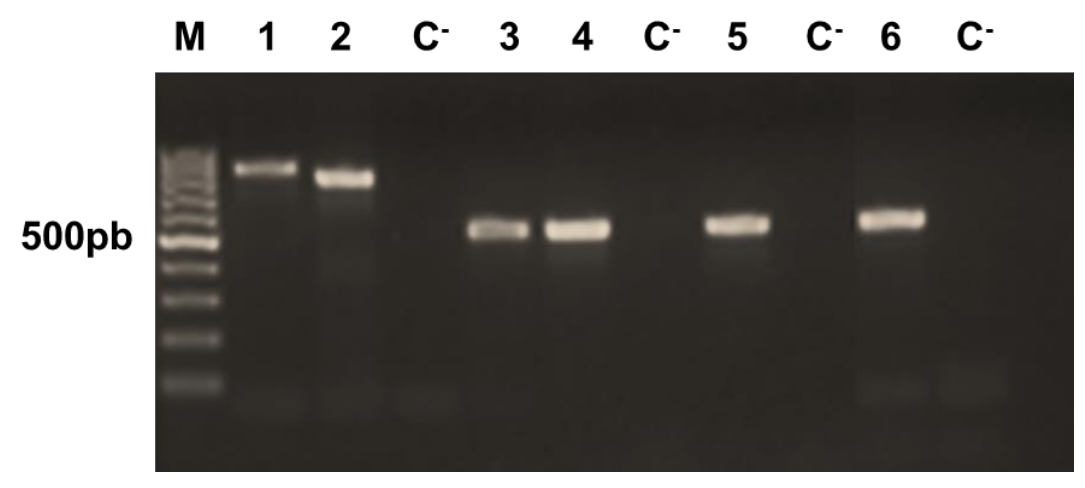

1 e 2: HAdV-2 e HAdV-31, respectivamente (aproximadamente 900 pb). 3 e 4: HHV-1 (597pb). 5: HHV-2 (597pb). 6: HEV (498pb). C: Controles negativos. M: Marcador de peso molecular 100pb $\left(\right.$ Biotools $\left.^{\circledR}\right)$. Eletroforese em gel de agarose 1,5\%. Registro digital obtido após exposição à luz UV.

Figura 13 - Perfil eletroforético dos produtos amplificados de HAdV, HEV e HHV-1 após a reação de Nested-PCR.
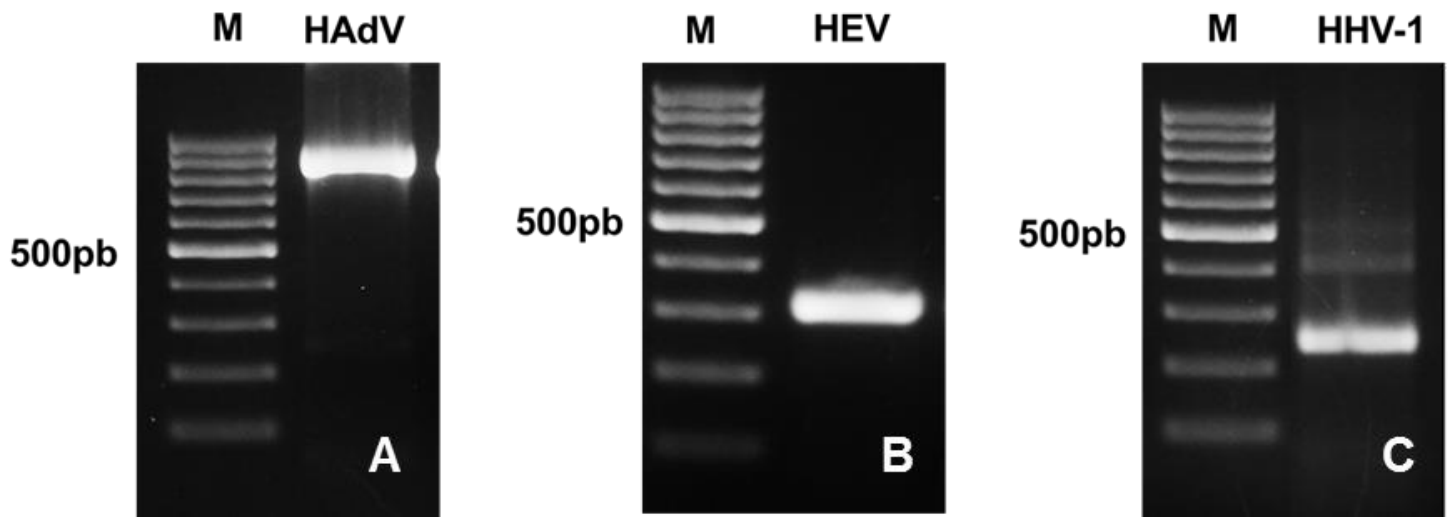

A: HAdV (825pb). B: HEV (308pb). C: HHV-1 (248pb). M: Marcador de peso molecular 100pb $\left(\right.$ Biotools $\left.^{\circledR}\right)$. Eletroforese em gel de agarose 1,5\%. Registro digital obtido após exposição à luz UV.

\subsection{Detecção de HAdV, HEV, HHV-1 e HHV-2 nas amostras de LCR através da técnica de Nested-PCR}

Após a análise das 273 amostras de LCR através da técnica de Nested-PCR para a detecção de HAdV, HEV e HHV-1/HHV-2, 40 (14,6\%) apresentaram resultados positivos para pelo menos um dos vírus pesquisados. Em 3 destas 40 amostras foram observados casos de coinfecção entre mais de um tipo de vírus. As figuras abaixo mostram os perfis 
eletroforéticos das amostras clínicas de LCR nas quais foram detectados HAdV, HEV e HHV-1/HHV-2 (Figuras 14, 15 e 16):

Figura 14 - Perfil eletroforético das amostras de LCR nas quais foram detectados HAdV após reação de Nested-PCR.

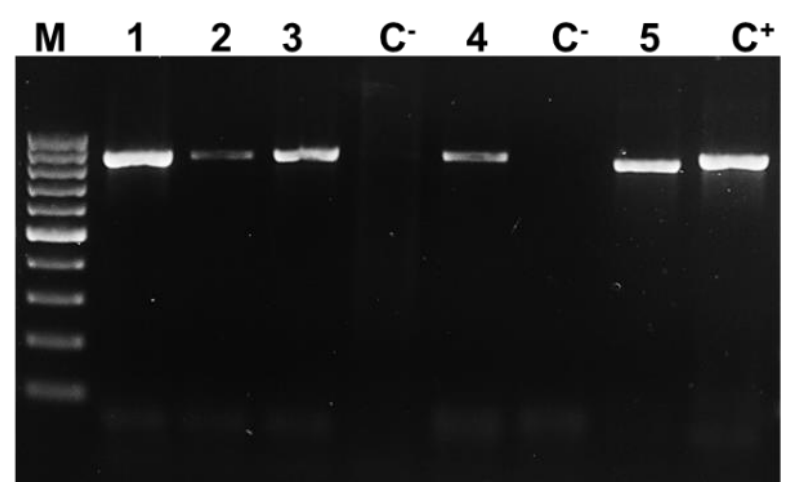

C: Controles negativos. C+: Controle positivo de HAdV na diluição $10^{-3}$. M: Marcador de peso molecular $100 \mathrm{pb}$ (Biotools ${ }^{\circledR}$ ). 1 a 5: amostras de LCR nas quais foram detectados HAdV. Eletroforese em gel de agarose 1,5\%. Registro digital obtido após exposição à luz UV.

Figura 15 - Perfil eletroforético das amostras de LCR nas quais foram detectados HEV após reação de Nested-PCR.

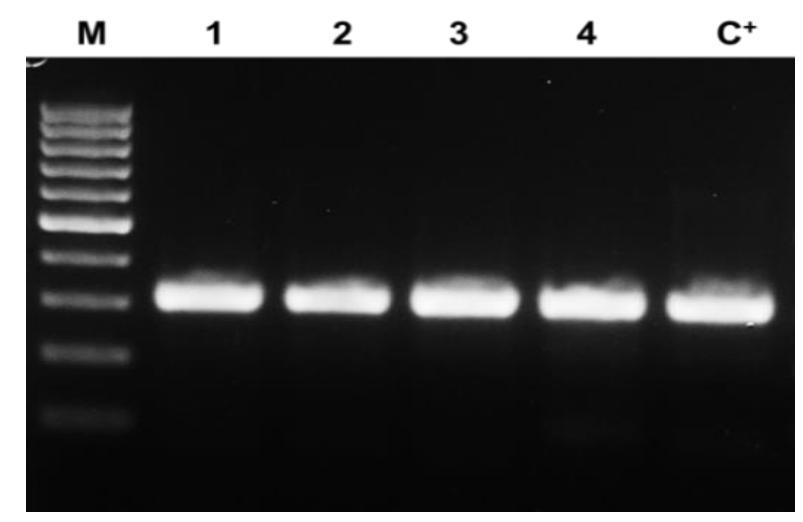

C+: Controle positivo de HEV na diluição $10^{-4}$. M: Marcador de peso molecular $100 \mathrm{pb}$ $\left(\right.$ Biotools $\left.^{\circledR}\right)$. 1 a 4: amostras de LCR nas quais foram detectados HEV. Eletroforese em gel de agarose $1,5 \%$. Registro digital obtido após exposição à luz UV. 
Figura 16 - Perfil eletroforético das amostras de LCR nas quais foram detectados HHV1/HHV-2 após reação de Nested-PCR.

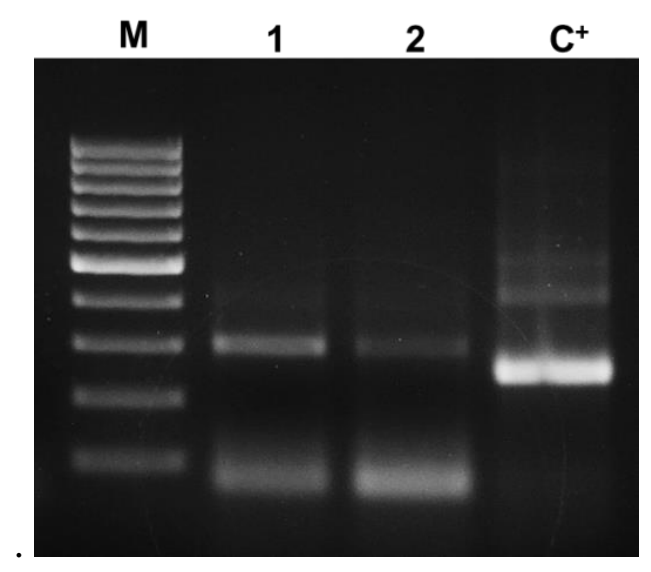

C+: Controle positivo de HHV-1. M: Marcador de peso molecular 100pb (Biotools ${ }^{\circledR}$ ). 1 e 2: amostras de LCR nas quais foram detectados HHV-1/HHV-2. Eletroforese em gel de agarose 1,5\%. Registro digital obtido após exposição à luz UV.

Considerando todas as 273 amostras analisadas, independentemente de suas características quimiocitológicas, e excluindo os casos de coinfecção, os HAdV foram detectados em 7/273 amostras (2,5\%), os HEV foram detectados em 27/273 amostras (9,8\%), e o DNA dos HHV-1 e HHV-2 foi detectado em 3/273 amostras (1,1\%). Foram observados, ainda, 3 casos de coinfecção: dois entre HEV e HHV e um entre HEV e HAdV. Tais dados são apresentados no gráfico a seguir (Figura 17):

Figura 17 - Frequência relativa de HAdV, HEV e HHV (HHV-1 e HHV-2) detectados em relação ao total de amostras de LCR analisadas.

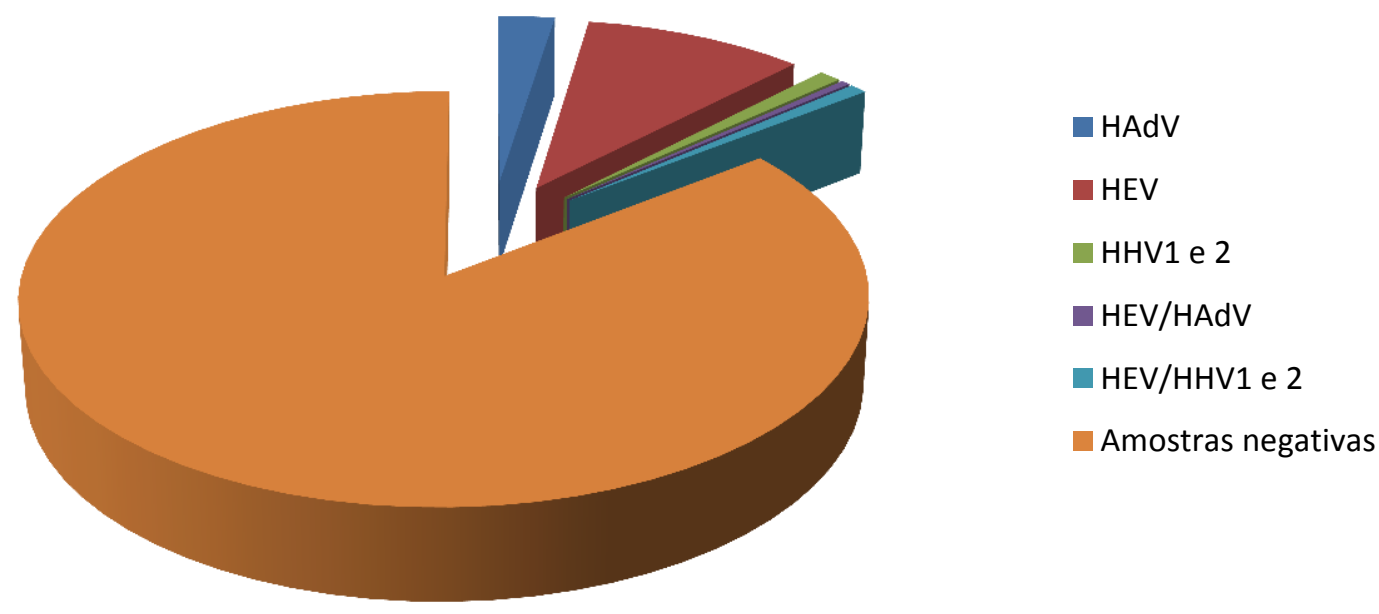




\subsection{Padronização da reação de PCR em tempo real}

\subsubsection{Reação de PCR em tempo real para a detecção de adenovírus}

As diluições seriadas do DNA de $\mathrm{HAdV}-2$ padrão foram submetidas às reações moleculares. A figura 18 apresenta os resultados obtidos após a reação de Nested-PCR, que possibilitou a detecção do DNA de adenovírus padrão até a diluição $10^{-6}$.

Figura 18 - Perfil eletroforético dos produtos amplificados das diluições do DNA extraído de HAdV-2 após a reação de Nested-PCR.

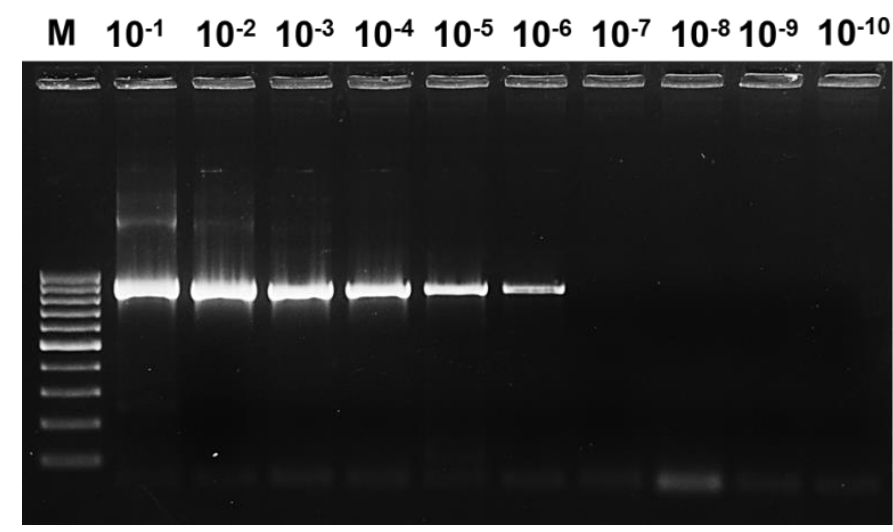

$\mathbf{1 0}^{-1}$ a $\mathbf{1 0}^{-10}$ : Diluições do DNA de HAdV-2 padrão de $10^{-1}$ a $10^{-10}$, respectivamente. M: Marcador de peso molecular 100pb (Biotools ${ }^{\circledR}$ ). Eletroforese em gel de agarose 1,5\%. Registro digital obtido após exposição à luz UV.

As mesmas diluições do DNA de HAdV-2 padrão foram submetidas à reação de PCR em tempo real. Além disto, duas amostras, já positivas através da Nested-PCR, foram testadas (HU 23/10 e 133/12).

A observação das curvas permite verificar que o início da amplificação das diluições do DNA do vírus padrão ocorreu próximo ao ciclo 15 (diluição $10^{-1}$ ) e terminou aproximadamente no ciclo $32\left(10^{-6}\right)$. Os Ct's das amostras HU 23/10 e 133/12 foram, aproximadamente, 19 e 39 respectivamente. Após análise da curva padrão observou-se slope de valor igual a - 3,384, e eficiência da reação de 97\%, ambos considerados muito bons. A curva de amplificação em escala logarítmica e a curva padrão obtidas são mostradas nas figuras abaixo (Figuras 19 e 20): 
Figura 19 - Curva de amplificação das diluições do DNA de HAdV-2 e das amostras de LCR HU 23/10 e 133/12 após reação de PCR em tempo real.

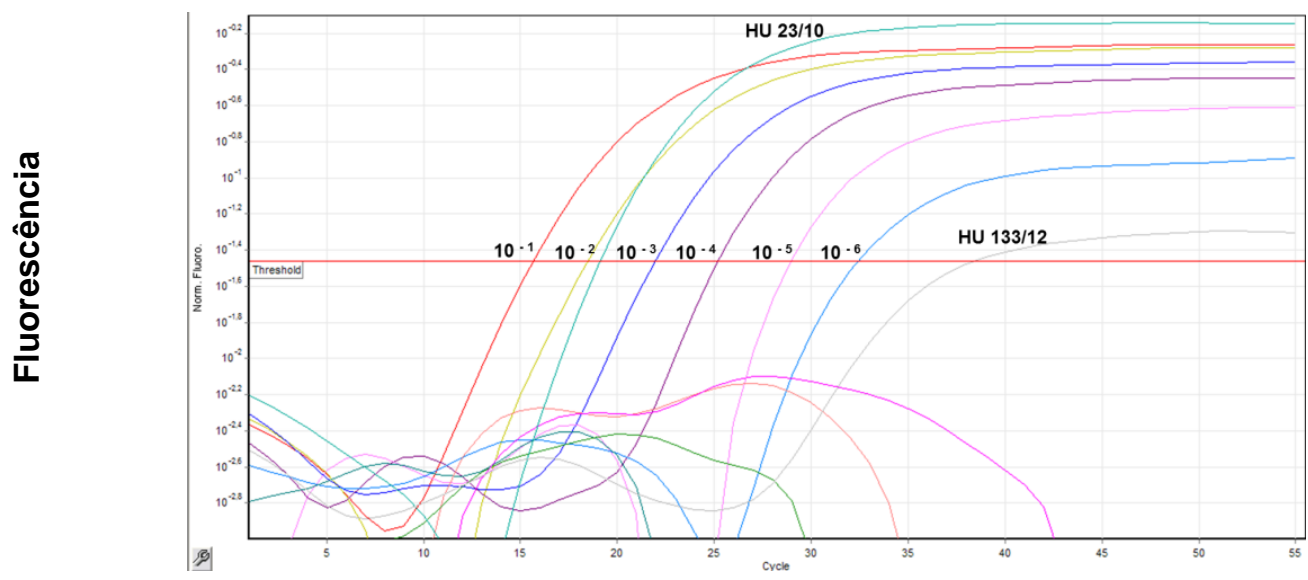

Ciclos

Figura 20 - Curva padrão correspondente às diluições do DNA de HAdV-2 e amostras de LCR HU 23/10 e 133/12 após reação de PCR em tempo real.

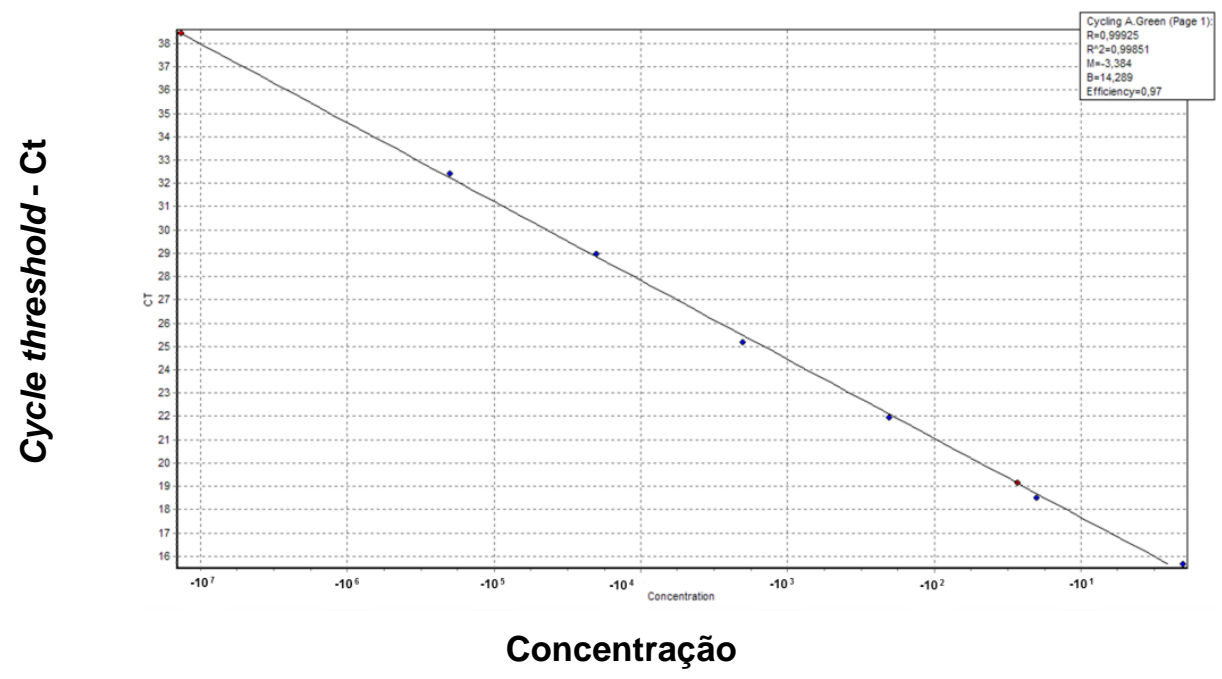

Como pode ser observado, tanto na reação de Nested-PCR quanto na PCR em tempo real, o limiar de detecção das diluições seriadas do DNA extraído viral foi de $10^{-6}$, o que indica, ainda que de forma preliminar, que a sensibilidade de ambas as reações é equivalente, de acordo com as condições estabelecidas neste estudo. 


\subsubsection{Reação de PCR em tempo real para a detecção de enterovírus}

As diluições seriadas do cDNA de Coxsackievírus B5 padrão foram submetidas às reações moleculares. A figura 21 apresenta os resultados obtidos após a reação de NestedPCR, que possibilitou a detecção do cDNA viral até a diluição $10^{-7}$.

Figura 21 - Perfil dos produtos amplificados das diluições do cDNA proveniente de enterovírus padrão (Coxsackievírus B5) após a reação de Nested-PCR.

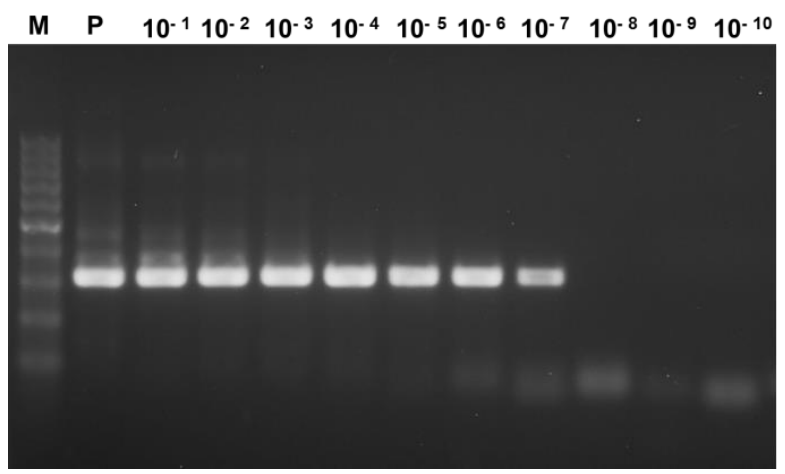

P: amostra pura, não diluída. $\mathbf{1 0}^{-1}$ a $\mathbf{1 0}^{-10}$ : Diluições do cDNA de HEV padrão de $10^{-1}$ a $10^{-10}$, respectivamente. M: Marcador de peso molecular 100pb (Biotools ${ }^{\circledR}$ ). Registro digital obtido após exposição à luz UV.

As diluições do cDNA de enterovírus (Coxsackievírus B5) foram, também, submetidas à reação de PCR em tempo real. Além das diluições do padrão, duas amostras, HU 02/10 e 137/12, já positivas através da Nested-PCR, foram testadas.

A observação das curvas permite verificar que o início da amplificação das diluições do cDNA padrão ocorreu aproximadamente no ciclo 15 (diluição $10^{-1}$ ) e terminou aproximadamente no ciclo $37\left(10^{-6}\right)$. O Ct da amostra HU 02/10 foi aproximadamente 40. Após análise da curva padrão observou-se slope de valor igual a - 3,751, e eficiência da reação de $85 \%$, ambos considerados bons. A amostra 137/12 foi submetida à reação de PCR em tempo real em outro momento e a presença de enterovírus foi confirmada. A curva de amplificação em escala logarítmica e a curva padrão obtidas são mostradas nas figuras abaixo (Figuras 22 e 23): 
Figura 22 - Curva de amplificação das diluições do cDNA de enterovírus (Coxsackievírus B5) e amostra de LCR HU 02/10 obtida após reação de PCR em tempo real.

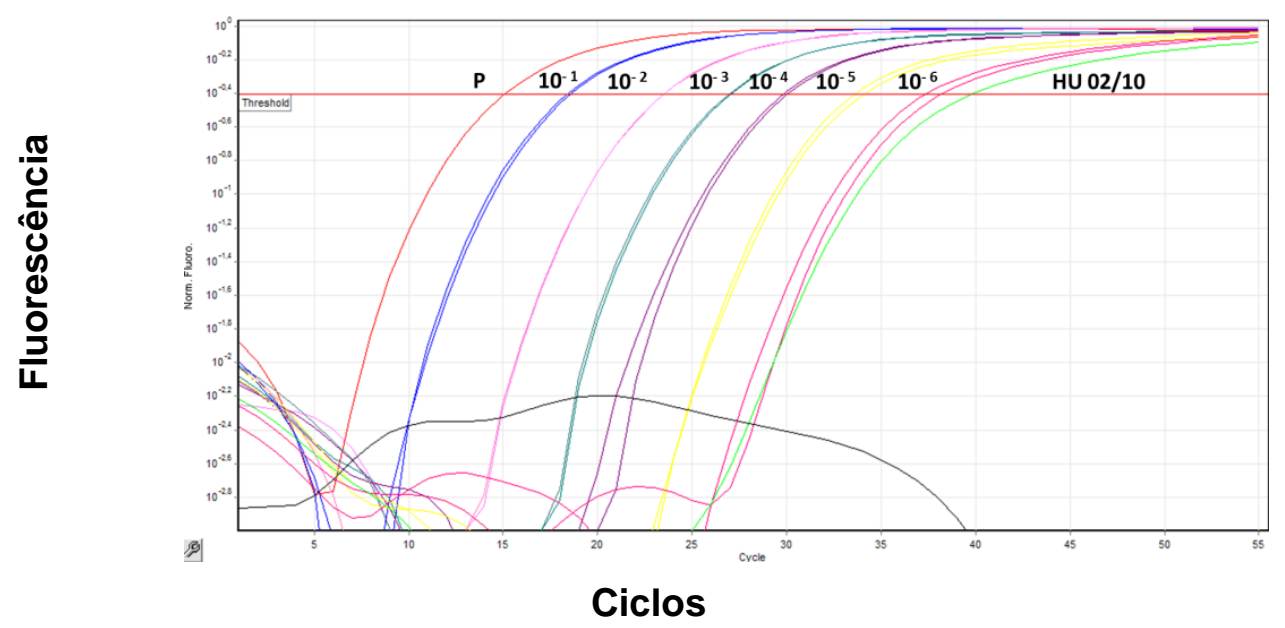

Figura 23 - Curva padrão das diluições do cDNA de enterovírus (Coxsackievírus B5) e amostra de LCR HU 02/10 obtida após reação de PCR em tempo real.

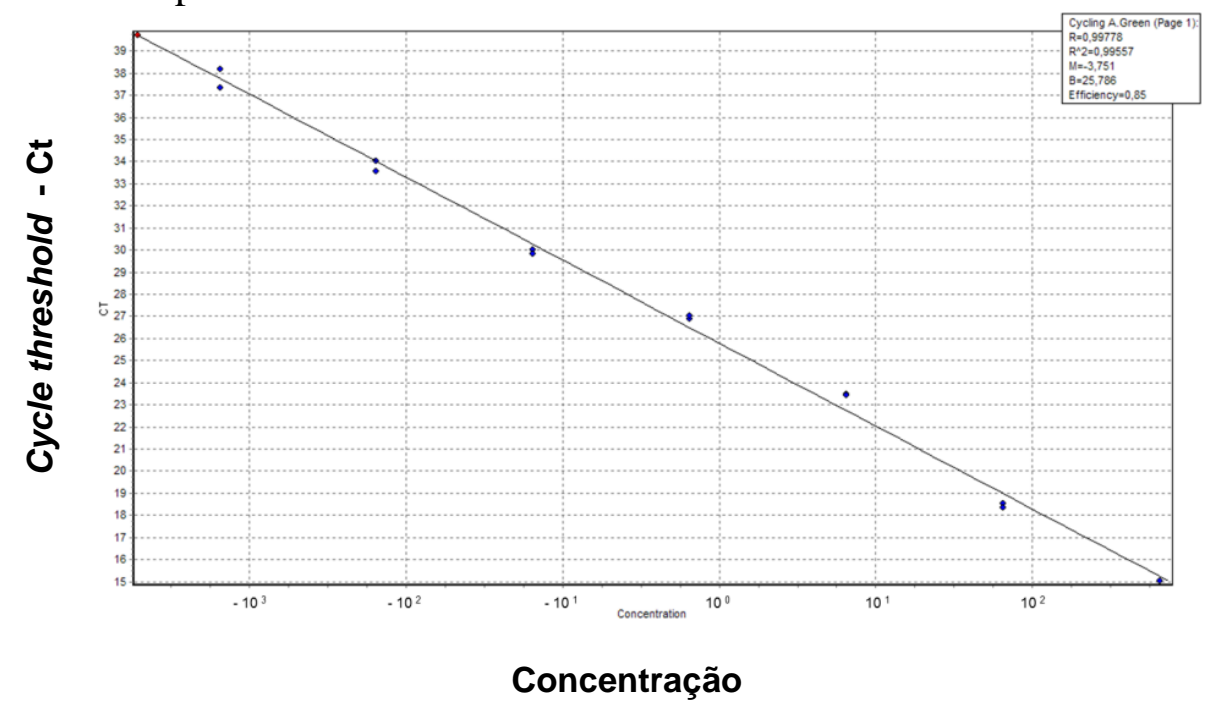

O limiar de detecção das diluições seriadas do cDNA viral observado na reação de Nested-PCR foi de $10^{-7}$, enquanto na PCR em tempo real o limiar observado foi de $10^{-6}$, de acordo com as condições estabelecidas neste estudo.

Cabe ressaltar, novamente, que esta é uma padronização preliminar, e a execução de novas reações, inclusive com a utilização de maior número de amostras clínicas, seguida de análises estatísticas, seria fundamental para a obtenção de resultados conclusivos. 


\subsubsection{Correlação entre o título viral dos HAdV e HEV e o limiar de detecção das reações moleculares}

Como relatado anteriormente, o título infeccioso do HAdV-2 padrão obtido através da técnica de Reed e Muench foi de $10^{3} \mathrm{DICT}_{50} / 25 \mu \mathrm{L}$ da suspensão viral. Considerando-se os $200 \mu \mathrm{L}$ utilizados para extração do DNA viral pelo método Qiaamp DNA Blood (Qiagen ${ }^{\circledR}$ ), o número de partículas virais infecciosas observado é oito vezes maior $\left(8 \times 10^{3}\right)$. Supondo-se que o DNA viral de todas as partículas infecciosas tenha sido devidamente extraído e submetido às reações moleculares, e considerando-se que a Nested-PCR e a PCR em tempo real foram, ambas, capazes de detectar o DNA viral até a diluição $10^{-6}$, observou-se que o limiar de detecção das reações moleculares foi de menos de 1 partícula infecciosa.

No caso dos HEV, o título do vírus padrão obtido através da técnica de Reed e Muench foi de $10^{6,5} \mathrm{DICT}_{50} / 25 \mu \mathrm{L}$ da suspensão viral. Considerando-se os $200 \mu \mathrm{L}$ utilizados para extração do DNA viral pelo método Qiaamp DNA Blood (Qiagen ${ }^{\circledR}$ ), o número de partículas virais infecciosas observado é oito vezes maior $\left(8 \times 10^{6,5}\right)$. Supondo-se que o RNA de todas as partículas virais infecciosas tenha sido devidamente extraído e submetido às reações moleculares, e considerando-se que a Nested-PCR foi capaz de detectar o DNA viral até a diluição $10^{-7}$ e a PCR em tempo real até a diluição $10^{-6}$, observou-se que o limiar de detecção das reações moleculares foi de 2,4 e 24 partículas infecciosas respectivamente.

\subsection{Análises clínico-epidemiológicas}

\subsubsection{Distribuição mensal das amostras positivas}

Amostras de líquor foram colhidas entre agosto e novembro de 2010 e entre fevereiro de 2012 e janeiro de 2013. No primeiro grupo (2010), não foi possível estabelecer uma relação de sazonalidade devido ao relativamente baixo número de amostras analisadas e ao curto período de colheita.

No mês de agosto/2010 foram processadas 3 amostras, das quais 1 continha HEV. Em setembro/2010 foram detectados HEV em 3 das 23 amostras analisadas. No mês de outubro/2010, 1 das 12 amostras apresentou coinfecção por HEV e HHV, e em novembro/2010 não foram detectados vírus em nenhuma das 4 amostras testadas.

No segundo período, que compreende fevereiro/2012 e janeiro/2013, correspondente a um ano de colheita (231 amostras analisadas), uma distribuição interessante das amostras 
positivas foi observada, com maior frequência de alguns dos vírus detectados em determinados períodos do ano. A frequência mensal das amostras positivas compreendidas neste período está exposta no gráfico abaixo (Figura 24):

Figura 24 - Frequência mensal das amostras positivas e negativas colhidas entre fevereiro/2012 e janeiro/2013 após reação de Nested-PCR para a detecção de HAdV, HEV e HHV-1/HHV-2.

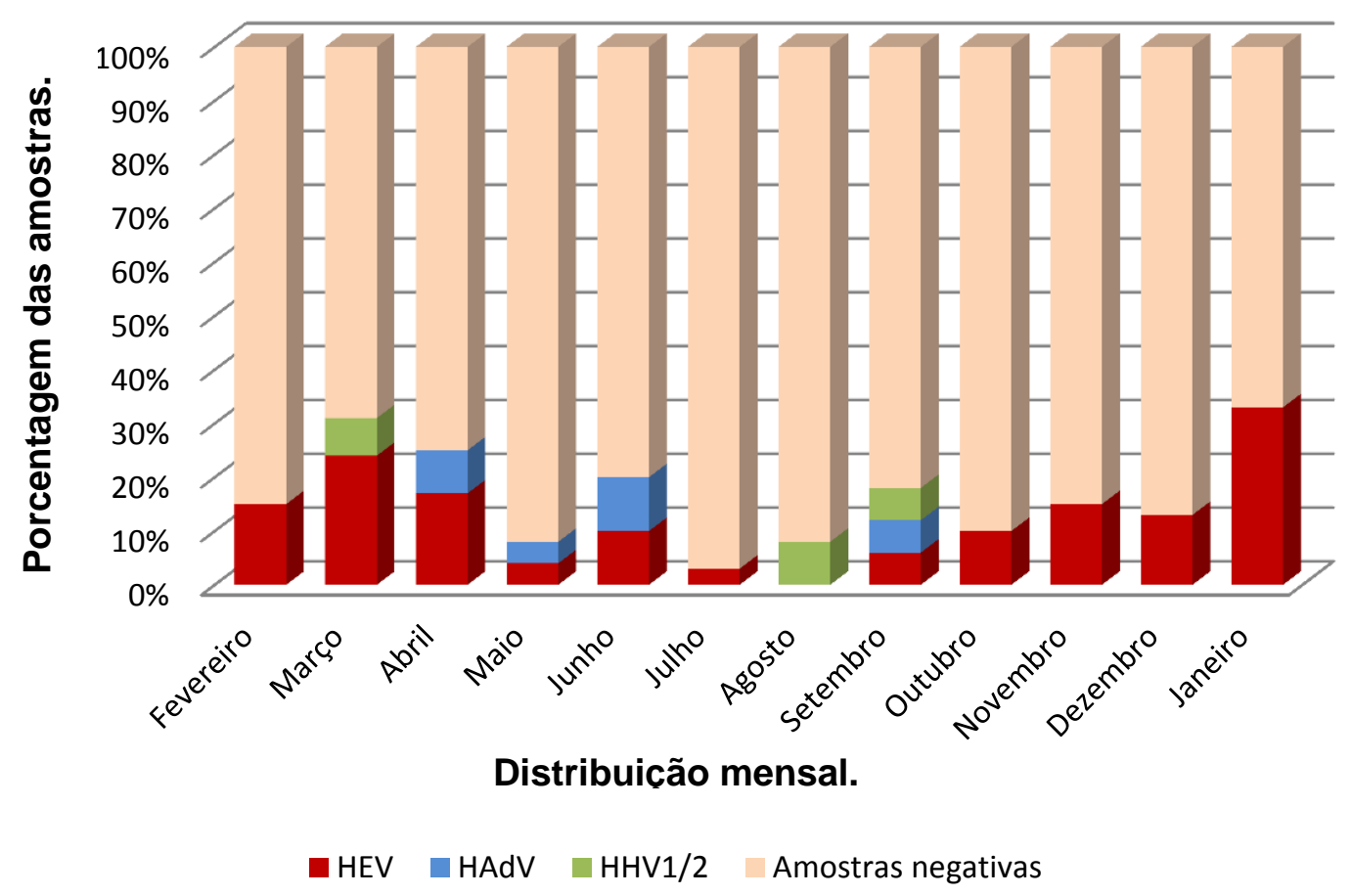

Neste gráfico pode-se observar que os enterovírus foram detectados ao longo de todo o período estudado, embora com maior frequência nos primeiros e últimos meses do ano (fevereiro a abril e outubro a janeiro), que apresentam temperatura mais elevada, com ocorrências em menor número nos demais meses. Destaca-se o mês de janeiro/2013, quando os HEV foram encontrados em 30\% das amostras analisadas. No caso dos adenovírus, nota-se que estão presentes nos meses mais centrais do ano, cuja temperatura é mais baixa no Estado de São Paulo, não sendo encontrados nos meses mais quentes do ano. Com relação aos HHV1 e 2, não foi observada relação de sazonalidade. 


\subsubsection{Relação entre a positividade das amostras de LCR e a faixa-etária dos pacientes}

As amostras de líquor foram distribuídas de acordo com a idade dos pacientes. Foi estabelecida uma correlação entra a faixa-etária de cada paciente e a efetiva detecção ou não de vírus na amostra. O gráfico a seguir apresenta a porcentagem de amostras positivas distribuídas por faixa-etária (Figura 25):

Figura 25 - Frequência de infecções do SNC por HAdV, HEV e HHV-1/HHV-2. Distribuição por faixa-etária.

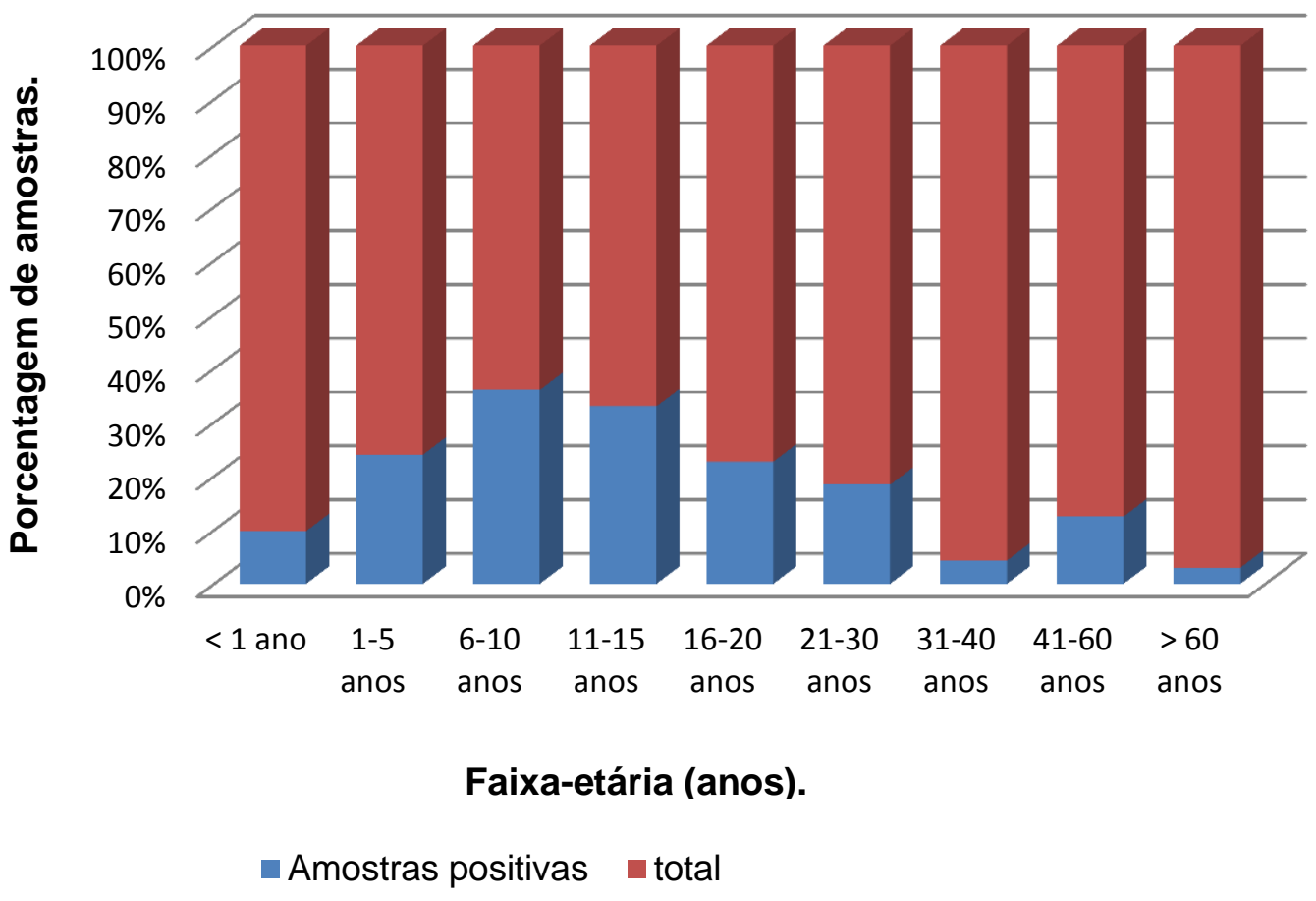

Observa-se que todas as faixas etárias foram atingidas, com maior frequência até os 20 anos de idade, correspondendo a 25 das 40 amostras nas quais foi detectado ao menos um dos vírus estudados. No grupo acima de 20 anos de idade foram encontradas 14 amostras positivas. Em uma amostra contendo adenovírus o dado referente à idade do paciente não foi informado.

A tabela a seguir especifica a positividade das amostras de líquor correlacionando o agente viral detectado e a faixa-etária dos pacientes (Tabela 3): 
Tabela 3 - Relação entre o agente viral detectado e a faixa-etária dos pacientes.

\begin{tabular}{ccccccccccc}
\hline $\begin{array}{c}\text { Idade } \\
\text { (anos) }\end{array}$ & $<1$ & 1 a 5 & 6 a 10 & 11 a 15 & 16 a 20 & 21 a 30 & 31 a 40 & 41 a 60 & $>60$ & Total \\
\hline HEV & 4 & 5 & 3 & 3 & 3 & 5 & 1 & 3 & 0 & 27 \\
\hline HAdV & 2 & 0 & 0 & 0 & 1 & 1 & 0 & 1 & 1 & 6 \\
\hline HHV1 e 2 & 0 & 0 & 0 & 0 & 1 & 1 & 0 & 1 & 0 & 3 \\
\hline $\begin{array}{c}\text { HEV / } \\
\text { HAdV }\end{array}$ & 1 & 0 & 0 & 0 & 0 & 0 & 0 & 0 & 0 & 1 \\
\hline $\begin{array}{c}\text { HEV/ } \\
\text { HHV1 e 2 }\end{array}$ & 0 & 1 & 1 & 0 & 0 & 0 & 0 & 0 & 0 & 2 \\
\hline $\begin{array}{c}\text { Total + / } \\
\text { total } \\
\text { colhidas }\end{array}$ & $7 / 71$ & $6 / 25$ & $4 / 11$ & $3 / 9$ & $5 / 22$ & $7 / 38$ & $1 / 23$ & $5 / 40$ & $1 / 33$ & $39 / 272$ \\
\hline \hline
\end{tabular}

Total +: total de amostras positivas por faixa-etária.

Total colhidas: Total de amostras colhidas por faixa-etária.

Observação: Uma das amostras, positiva para HAdV, pertencia a um paciente cuja idade não foi informada.

Os HEV foram observados em todas as faixas etárias, inclusive em adultos, embora sua maior frequência tenha sido em pacientes com até 20 anos de idade. Os adenovírus também foram detectados em adultos e jovens, embora 2 casos tenham se concentrado em crianças abaixo de 1 ano de idade. Com relação aos HHV-1 e HHV-2, as 3 amostras positivas foram encontradas em pacientes jovens e adultos. No caso das coinfecções, é interessante notar sua ocorrência apenas em crianças.

\subsubsection{Relação entre o quadro clínico dos pacientes e a positividade das amostras}

A relação entre o quadro clínico dos pacientes, estabelecido e anotado nos prontuários pelo médico durante o atendimento, e a efetiva detecção dos vírus nas respectivas amostras de líquor foi avaliada. Os resultados observados estão expressos tanto em relação à positividade geral das amostras, quanto aos agentes virais especificamente relacionados a cada quadro clínico (Tabelas 4 e 5).

Verifica-se que, em 35\% (14/40) das amostras nas quais foram detectados vírus, a suspeita clínica já mencionava meningite ou até mesmo meningite viral. Em outros 25\% (10/40) das amostras positivas, apenas a sintomatologia relatada ou observada foi registrada como quadro clínico. Nota-se, porém, que todos os sintomas referidos podem fazer parte do quadro clínico de infecções do SNC (cefaleia/febre, convulsão e confusão mental). Febre sem 
sinal localizatório e sepse corresponderam a 7,5\% (3/40), cada um, das amostras positivas. No grupo denominado "outros", foram relacionadas as amostras cujos quadros clínicos não apresentavam relação com a sintomatologia das infecções do SNC, representando $25 \%$ (10/40) das amostras nas quais foram detectados vírus. 


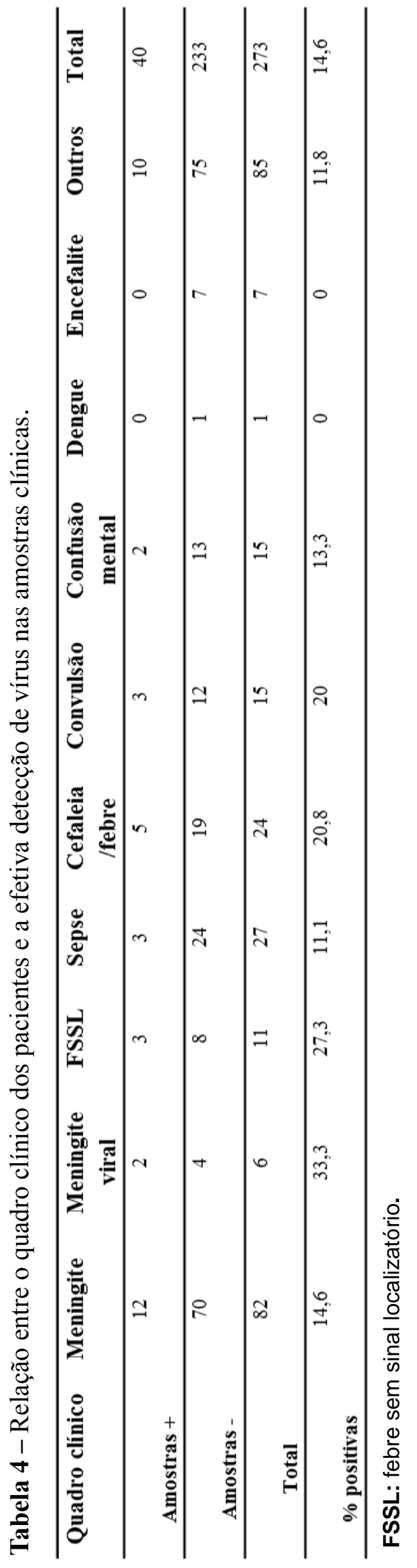




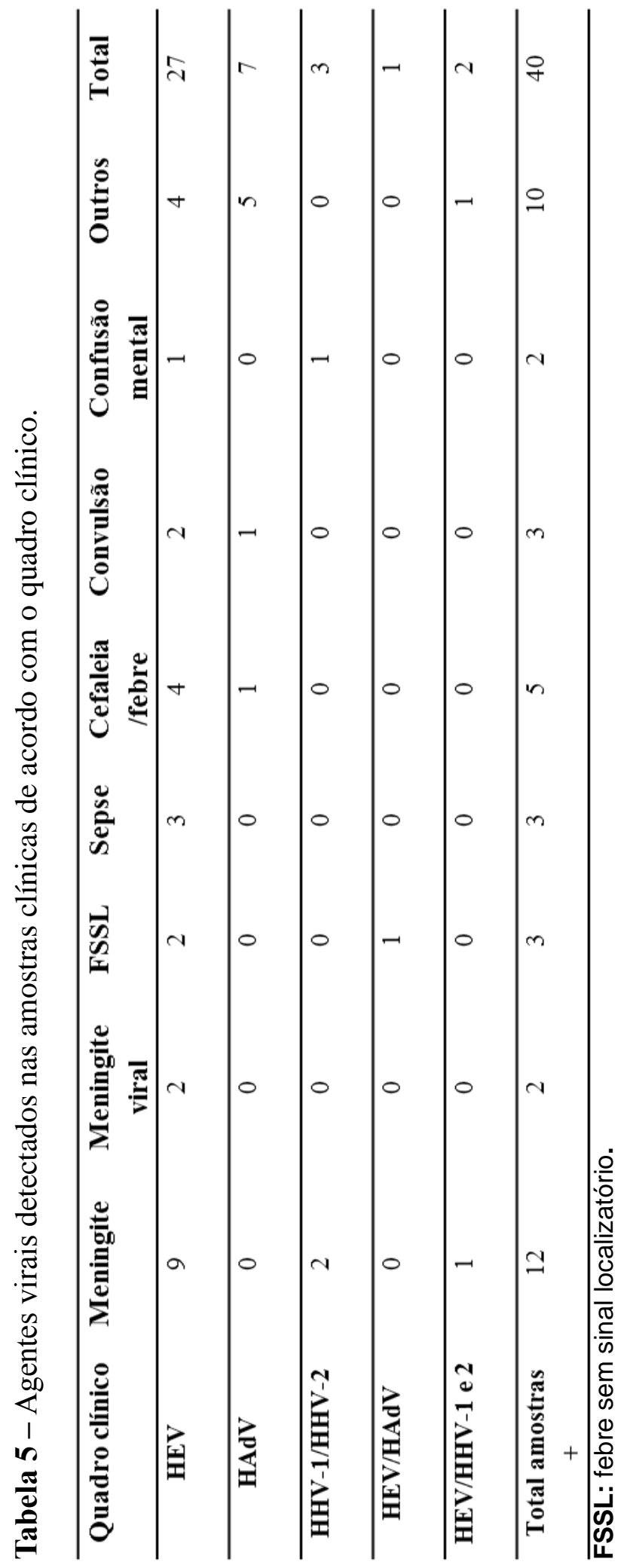




\subsection{Análise quimiocitológica do LCR}

As características quimiocitológicas das amostras de LCR foram analisadas e correlacionadas à presença ou não de vírus. Foram analisados: celularidade, predomínio de linfócitos ou neutrófilos, níveis de proteínas e glicose. Os dados quimiocitológicos das amostras de LCR coletadas foram obtidos do banco de dados do laboratório clínico do Hospital Universitário da USP.

Das 273 amostras de LCR, apenas 97 (35,5\%) apresentavam celularidade elevada, ou seja, superior a 4 células $/ \mathrm{mm}^{3}$. Este é um dado importante, já que o aumento do número de células no LCR constitui um dos principais fatores indicativos de infecção do SNC. As demais 176 amostras $(64,5 \%)$ apresentaram quantidades consideradas normais, tipicamente chamadas de amostras com celularidade negativa ( 0 a 4 células/ $\mathrm{mm}^{3}$ ). Em geral, amostras com níveis celulares normais não condizem com quadros de alteração ou infecção do SNC. A tabela a seguir mostra a distribuição das amostras colhidas de acordo com a celularidade (Tabela 6):

Tabela 6 - Distribuição das amostras de LCR de acordo com a celularidade observada após análise quimiocitológica.

\begin{tabular}{|c|c|c|c|c|c|c|}
\hline $\begin{array}{c}\text { Celularidade } \\
\left(\mathbf{n}^{\mathbf{0}} \text { células } / \mathbf{m m}^{3}\right)\end{array}$ & 0 a 4 & 5 a 100 & 101 a 500 & 501 a 1000 & $>1000$ & Total \\
\hline Amostras (+) & 16 & 14 & 6 & 1 & 3 & 40 \\
\hline Amostras (-) & 160 & 59 & 9 & 3 & 2 & 233 \\
\hline Total & 176 & 73 & 15 & 4 & 5 & 273 \\
\hline
\end{tabular}

Na tabela a seguir (Tabela 7), apresentamos a celularidade das amostras de LCR nas quais foram detectados agentes virais. Convém ressaltar que, dentre as amostras com celularidade superior a 500 células $/ \mathrm{mm}^{3}$, encontram-se algumas das infecções causadas por HEV e HHV-1/HHV-2. Dentre as amostras nas quais foram detectados HEV e HAdV, foram observados casos cuja celularidade apresentou-se negativa. Em todas as amostras nas quais foram detectados HHV-1/HHV-2 e nos casos de coinfecção, o número de células estava aumentado. 
Tabela 7 - Correlação entre os vírus detectados e a celularidade das amostras de LCR.

\begin{tabular}{cccc}
\hline \hline $\begin{array}{c}\text { Vírus } \\
\text { detectado }\end{array}$ & $\begin{array}{c}\text { Amostras positivas com } \\
\text { celularidade positiva } \\
\left(>5 \text { células/ } \mathbf{~ m m}^{3}\right)\end{array}$ & $\begin{array}{c}\text { Amostras positivas com } \\
\text { celularidade negativa } \\
\left(\mathbf{0} \text { a } 4 \text { células/ } \mathbf{~ m m}^{3}\right)\end{array}$ & Total \\
\hline HEV & $17(63 \%)$ & $10(37 \%)$ & 27 \\
\hline HAdV & $1(14,3 \%)$ & $6(85,7 \%)$ & 3 \\
\hline HHV1 e 2 & $3(100 \%)$ & 0 & 1 \\
\hline HEV/HAdV & $1(100 \%)$ & 0 & 2 \\
\hline HEV/ HHV1 e 2 & $2(100 \%)$ & 0 & 40 \\
\hline Total & $24(60 \%)$ & $16(40 \%)$ & 3 \\
\hline \hline
\end{tabular}

De acordo com a tabela acima, observa-se que $60 \%$ das amostras de LCR, nas quais algum agente viral pesquisado foi encontrado, apresentavam níveis celulares aumentados de acordo com o preconizado pelo Ministério da Saúde (2010). No entanto, em 40\% das amostras positivas para algum agente viral a celularidade encontrava-se normal.

Como mostrado anteriormente, em 40 das 273 amostras de LCR analisadas foi detectado pelo menos um dos agentes virais pesquisados, o que representa uma porcentagem de $14,6 \%$. Esta frequência aumenta significativamente se for avaliada a relação entre as amostras positivas e com celularidade aumentada (24 das 40 amostras positivas totais) e o número total de amostras com celularidade aumentada (97 das 273 amostras totais). Neste caso, verifica-se uma positividade de 24,7\% (24/97), bastante superior aos 14,6\% encontrados quando o universo considerado inclui amostras tanto com celularidade positiva quanto negativa.

Por outro lado, agentes virais também foram detectados em amostras com celularidade negativa. Das 176 amostras com menos de 4 células $/ \mathrm{mm}^{3}, 16$ foram positivas para algum dos vírus pesquisados, representando $9,1 \%$.

No que tange ao predomínio celular observado nas amostras com celularidade aumentada, a tabela seguinte (Tabela 8) reflete a distribuição de neutrófilos, linfócitos e monócitos. 
Tabela 8 - Distribuição das amostras positivas e com celularidade aumentada em relação ao predomínio de neutrófilos, linfócitos ou monócitos.

\begin{tabular}{ccccc}
\hline \hline Tipo celular predominante & Neutrófilos & Linfócitos & Monócitos & Total \\
\hline $\begin{array}{c}\mathbf{N}^{\mathbf{0}} \text { de amostras positivas e } \\
\text { com celularidade aumentada } \\
\text { nas quais o predomínio foi } \\
\text { observado }\end{array}$ & 11 & 13 & 0 & 24 \\
\hline \begin{tabular}{c} 
Porcentagem \\
\hline \hline
\end{tabular}
\end{tabular}

Embora a diferença observada entre o predomínio de linfócitos e neutrófilos tenha sido pequena $(54,2 \%$ e $45,8 \%$, respectivamente), o primeiro tipo celular ainda foi o mais encontrado.

Com relação à alteração nos níveis de proteínas, todas as amostras foram analisadas, positivas e negativas. $\mathrm{O}$ resultado desta análise encontra-se na tabela 9.

Tabela 9 - Níveis de proteínas das amostras de LCR analisadas.

\begin{tabular}{cccc}
\hline \hline Níveis de proteínas & $\begin{array}{c}\text { Proteínas } \\
\text { normais }\end{array}$ & $\begin{array}{c}\text { Proteínas } \\
\text { alteradas }\end{array}$ & Total \\
\hline Amostras positivas & $26(65 \%)$ & $14(35 \%)$ & $\mathbf{4 0}(\mathbf{1 0 0 \% )}$ \\
\hline Amostras negativas & $136(58,4 \%)$ & $97(41,6 \%)$ & $\mathbf{2 3 3 ( 1 0 0 \% )}$ \\
\hline Total & $\mathbf{1 6 2}$ & $\mathbf{1 1 1}$ & $\mathbf{2 7 3}$ \\
\hline \hline
\end{tabular}

Níveis normais de proteínas: 15 a $50 \mathrm{mg} / \mathrm{dL}$ (BRASIL, 2010).

Pode ser observado que a maioria das amostras positivas apresentou níveis de proteínas normais, e em significativa parte das amostras negativas as proteínas estavam alteradas. Nos casos analisados, tais resultados não se mostraram bons indicadores de alteração ou infecção do SNC.

Os níveis de glicose no LCR também foram avaliados. De acordo com o disposto pelo Ministério da Saúde (2010), os valores de referência variam de 45 a $100 \mathrm{mg} / \mathrm{dL}$, cerca de 2/3 da glicose sanguínea. Por isso é fundamental que os níveis séricos deste composto sejam avaliados simultaneamente aos observados no líquor. No entanto, após análise dos 
dados disponíveis verificou-se que, na maioria dos casos, apenas os níveis liquóricos foram informados. A tabela a seguir apresenta os níveis de glicose das amostras de líquor, tanto positivas quanto negativas (Tabela 10):

Tabela 10 - Níveis de glicose das amostras de LCR analisadas.

\begin{tabular}{|c|c|c|c|c|}
\hline \multirow[t]{2}{*}{ Níveis de glicose } & \multirow{2}{*}{$\begin{array}{l}\text { Glicose } \\
\text { Normal }\end{array}$} & \multicolumn{2}{|c|}{ Glicose alterada } & \multirow[t]{2}{*}{ Total } \\
\hline & & Baixa & Alta & \\
\hline Amostras positivas & $36(90 \%)$ & $\begin{array}{c}4 \\
(10 \%)\end{array}$ & $\begin{array}{c}0 \\
(0 \%)\end{array}$ & $40(100 \%)$ \\
\hline Amostras negativas & $208(89,3 \%)$ & $\begin{array}{c}16 \\
(6,9 \%) \\
\end{array}$ & $\begin{array}{c}9 \\
(3,8 \%) \\
\end{array}$ & $233(100 \%)$ \\
\hline Total & 244 & 20 & 9 & 273 \\
\hline
\end{tabular}

Níveis de glicose considerados normais: 45 a $100 \mathrm{mg} / \mathrm{dL}$ (BRASIL, 2010).

Em apenas 11 amostras os níveis séricos de glicose estavam disponíveis, e em todos os casos a proporção entre a glicose no líquor e no sangue estava em torno de $2 / 3$, valores considerados normais. Dentre as amostras positivas, 4 apresentaram níveis baixos de glicose: 2 nas quais foram detectados herpesvírus, 1 contendo adenovírus e 1 positiva para enterovírus.

Os casos nos quais foram observados altos níveis de glicose podem ser justificados pela possível elevação, também, da glicose sanguínea, o que é apenas uma possibilidade, já que as taxas de glicose sérica não foram disponibilizadas para tais amostras.

Um dos critérios de inclusão das amostras de LCR neste estudo foi a ausência de bactérias, comprovada pela cultura com resultado negativo. Uma amostra, porém, na qual foram encontradas bactérias (Streptococcus pneumoniae), foi enviada equivocadamente e também testada para a detecção de vírus, embora com resultados negativos. Esta amostra apresentou glicose de $29 \mathrm{mg} / \mathrm{dL}$, condizente com o esperado em casos de infecções bacterianas do SNC. 


\section{DISCUSSÃO}

As infecções do SNC acometem milhões de pessoas em todo o mundo (OMS, 2010). As meningites virais merecem destaque em Saúde Pública e são doenças de notificação compulsória no Brasil (BRASIL, 2010). Quantitativamente, os vírus são os principais agentes etiológicos envolvidos, e mesmo não causando infecções tão severas quanto às de etiologia bacteriana, destacam-se pela magnitude de sua ocorrência e relevância social (ROOS, 2005).

Entre os vírus relacionados a quadros de infecção do SNC podem ser citados os enterovírus, os herpesvírus (herpesvírus humanos tipos 1 e 2, vírus Varicela Zoster, vírus Epstein Barr, citomegalovírus, e herpesvírus humano do tipo 6), os adenovírus, os arbovírus e o vírus da imunodeficiência humana (HIV), embora outros possam, também, estar associados a tais infecções (DORIAN; KANG, 2011; HANDIQUE, 2011; IRANI, 2008; LOGAN; MacMAHON, 2008; STHAL et al., 2011). Neste estudo foram contemplados os adenovírus, enterovírus e herpesvírus dos tipos 1 e 2.

A grande maioria dos casos de infecção viral do SNC observados está associada aos enterovírus, e em geral representam infecções de baixa gravidade, curso benigno e bom prognóstico. Os herpesvírus dos tipos 1 e 2 são responsáveis por cerca de $0,5 \%$ a $3 \%$ dos casos de meningite viral aguda, e podem estar relacionados a quadros graves de encefalite, com altas taxas de mortalidade e grande potencial de deixar sequelas (SÃO PAULO, 2006; SIMKO et al., 2002). Os adenovírus foram associados a casos esporádicos de infecções do SNC, embora alguns trabalhos tenham detectado estes agentes virais em quantidades significativas nas amostras de líquor analisadas (LEMA; CISTERNA; FREIRE, 2005; SANTOS, 2009).

O termo arbovírus faz referência ao modo de transmissão do agente viral, que ocorre através de artrópodes, como os mosquitos, e pode incluir várias famílias virais, merecendo destaque os flavivírus (vírus da dengue, febre amarela, Saint Louis, West Nile) e os alfavírus (Eastern Equine Encephalitis virus, Western Equine Encephalitis virus e Venezuelan Equine Encephalitis virus). Estes vírus estão associados a surtos ocorridos na América do Norte, América Central e Europa, e a casos esporádicos observados na América do Sul, inclusive no Brasil (FIGUEIREDO, 2000; MONDINI et al., 2007). Grande parte das infecções é assintomática, mas podem ocorrer quadros de meningite e encefalite, caracterizados por infecções leves a severas, neste último caso, com alta taxa de mortalidade e produção de sequelas para alguns dos vírus em questão (GRIFFIN, 2007; GUBLER; KUNO; MARCKOFF, 2007; MENDOZA et al., 2007; STAHL et al., 2011). 
O diagnóstico clássico das infecções virais do SNC baseou-se, durante muito tempo, no isolamento viral a partir de amostras de líquor e fezes, seguido de confirmação por métodos sorológicos, consistindo nas únicas metodologias disponíveis para esta finalidade.

O cultivo possibilita o aumento do número de partículas virais, facilitando sua detecção e caracterização, e é o único método capaz de isolar vírus viáveis que podem ser armazenados e estudados futuramente, além de permitir a detecção de outros vírus que não os procurados pela suspeita diagnóstica, possibilitando, inclusive, a descoberta de agentes virais ainda não conhecidos (STORCH, 2007).

Como técnica com função diagnóstica, e quando se trata de infecções virais do SNC, no entanto, os métodos clássicos, como o cultivo viral, são em geral insatisfatórios. O tempo consumido até o diagnóstico final pode variar de duas semanas a um mês, e não condiz com o tratamento urgente exigido pelo paciente nestes casos. Além disso, a variedade de vírus que pode ser detectada é relativamente pequena (STORCH, 2007). Muitos vírus são de difícil cultivo ou não são cultiváveis (a grande parte dos enterovírus, por exemplo), e a observação de um efeito citopático claro pode ser prejudicada pela pequena quantidade de vírus nas amostras clínicas, fato a ser considerado quando se trata do liquor (PALLANSCH; ROSS, 2007). Quando o isolamento ocorre através das fezes, outro problema é encontrado, já que pode haver a identificação preferencial de outro vírus entérico que não o causador da infecção do SNC. Atualmente, o cultivo celular acaba restrito a laboratórios de pesquisa e de referência, para a confirmação diagnóstica e, principalmente, para a obtenção de dados epidemiológicos.

Embora o objetivo do uso das culturas celulares no presente estudo tenha sido a produção de vírus padrão e sua titulação, e não a detecção de vírus nas amostras clínicas através do isolamento viral, deve ser destacada a oportunidade oferecida para o conhecimento e aplicação de técnicas clássicas, únicas disponíveis durante muito tempo para o isolamento dos vírus e diagnóstico de infecções virais. Sua aplicação possibilitou entender e observar, na prática, os princípios básicos da multiplicação celular e da interação vírus x célula, abordagens que não devem ser esquecidas, mesmo em meio à crescente importância adquirida pelo diagnóstico molecular.

As técnicas convencionais como o cultivo viral, a detecção de antígenos e a pesquisa de anticorpos específicos apresentam limitações de sensibilidade, especificidade, tempo de execução e custo quando comparadas às reações moleculares. As técnicas moleculares têm adquirido importância em virtude de sua alta especificidade, sensibilidade e rapidez, e são comuns nos laboratórios de pesquisa. Sua importância também é crescente no que se refere a 
estudos epidemiológicos. No entanto, a implantação destes métodos no diagnóstico de rotina em laboratórios clínicos ainda está sendo estabelecida, e embora sua utilização seja crescente, não configuram testes diagnósticos validados, sendo considerados como técnicas de diagnóstico complementar (BRASIL, 2010; CINQUE; BOSSOLASCO; LUNDIKVIST, 2003; COLIMON, 2002; IRANI, 2008; THOMSON; BERTRAM, 2001).

Atualmente, grande parte dos trabalhos cujo objetivo é estudar a etiologia das infecções do SNC utiliza as reações moleculares como ferramenta. Muitos autores sugerem que as técnicas de PCR tendem a se tornar referência no que tange ao diagnóstico destas infecções. Jeffery e colaboradores (1997) já defendiam que a PCR se tornaria um teste de diagnóstico de primeira linha nestes casos.

Além das reações convencionais de PCR e Nested-PCR, deve ser destacada a introdução da técnica de PCR em tempo real, ainda mais sensível, específica e rápida que as anteriores, e que oferece um diagnóstico mais preciso e confiável, devido à redução da manipulação das amostras e do risco de contaminação por produtos de PCR, além da geração e leitura automatizadas dos resultados.

Em estudo desenvolvido por Pollage e Petti (2006), técnicas de diagnóstico molecular foram comparadas ao cultivo viral para a detecção de enterovírus e herpesvírus em amostras de líquor. Os autores concluíram que, no caso dos vírus acima citados, as técnicas moleculares foram muito superiores em termos de diagnóstico, e que a realização do cultivo viral, além de mais demorado, envolveu gastos desnecessários e ofereceu muito pouco ou nenhum benefício adicional ao paciente. No entanto, reconheceram que, quando a suspeita clínica é direcionada para agentes infecciosos raros associados à infecção do SNC, para os quais as técnicas moleculares ainda não estão bem estabelecidas, o isolamento viral pode ser de grande importância.

Considerando-se a discussão acima ficou decidido, neste trabalho, que a detecção dos vírus associados a quadros de infecção do SNC seria realizada através de técnicas moleculares (Nested-PCR e PCR em tempo real), visando à maior agilidade, especificidade e sensibilidade no diagnóstico de adenovírus, enterovírus e herpesvírus dos tipos 1 e 2, com o objetivo de serem estabelecidas técnicas apropriadas para a introdução futura na rotina clínica como método de diagnóstico complementar das infecções virais do SNC.

Para que as reações moleculares fossem realizadas, a extração prévia dos ácidos nucleicos virais foi necessária. Para tal foram utilizados dois métodos de extração, ambos disponíveis comercialmente: Qiaamp ${ }^{\circledR}$ DNA Blood $\left(\right.$ Qiagen $^{\circledR}$ ) e MagMAX ${ }^{T M}$ Viral RNA Isolation (Ambiom). 
O primeiro método, Qiaamp ${ }^{\circledR}$ DNA Blood (Qiagen ${ }^{\circledR}$ ), foi considerado como mais sensível e específico em estudo realizado por Santos (2009), quando comparado à extração com fenol/clorofórmio (CHOMCZYNSKY; SACCHI, 1987) e à técnica de extração com tiocianato de guanidina (MARKOULATOS et al., 2001). No presente estudo, o referido método foi comparado ao MagMAX ${ }^{T M}$ Viral RNA Isolation (Ambiom), método este semiautomático e disponível para utilização no Hospital Universitário da USP.

O método Qiaamp ${ }^{\circledR}$ DNA Blood $\left(\right.$ Qiagen $^{\circledR}$ ) baseia-se na adsorção dos ácidos nucleicos a uma membrana de sílica-gel. A adição de um tampão de lise e de protease fornecidos pelo fabricante permite a lise das células e partículas virais presentes na amostra, a estabilização dos ácidos nucleicos e o aumento da seletividade da ligação entre o DNA e RNA e a membrana de sílica-gel. O pH e a concentração de sais do lisado garantem que proteínas e outros contaminantes, que podem inibir a reação de PCR, sejam eliminados. Após adição de tampão de lavagem seguida de centrifugação, eventuais resíduos são eliminados e a pureza do material extraído é aumentada, sem afetar a ligação dos ácidos nucleicos à membrana. $\mathrm{Na}$ última etapa do processo o DNA e RNA são eluídos com auxílio de um tampão fornecido pelo fabricante $\left(\right.$ Qiaamp $^{\circledR} \ldots$, 2007).

O princípio do método MagMAX ${ }^{T M}$ Viral RNA Isolation (Ambiom) fundamenta-se na ligação dos ácidos nucleicos a beads (microesferas) magnéticas. Emprega a técnica clássica da lise das amostras através de uma solução base de tiocianato de guanidina, capaz de liberar o DNA e RNA viral além de inativar, simultaneamente, as nucleases presentes na matriz da amostra (CHIRGWIN, et al., 1979; CHOMCZYNSKI; SACCHI, 1987). As microesferas magnéticas possuem uma grande superfície de ligação e são capazes de serem dispersas amplamente na solução, permitindo a ligação aos ácidos nucleicos, que é seguida das etapas de lavagem e eluição, quando o material genético é recuperado (MagMAX ${ }^{T M}$..., 2008).

Dentre as amostras de líquor analisadas neste trabalho, um subconjunto de 104 foi extraído por ambos os métodos descritos acima. O intervalo de tempo entre a extração por um ou outro método foi de cerca de uma semana, visando à minimização de perdas relacionadas ao armazenamento das amostras e à garantia da qualidade dos ácidos nucleicos.

Depois de extraídas, as amostras foram submetidas às reações de PCR e Nested-PCR para a detecção de adenovírus, enterovírus e herpesvírus dos tipos 1 e 2. Verificou-se que, em 6 delas, foram detectados vírus após a extração por ambos os métodos; em 5, foram detectados vírus apenas após extração pelo método MagMAX ${ }^{T M}$ Viral RNA Isolation (Ambiom); em 2, a detecção viral ocorreu somente após extração através do método 
Qiaamp $^{\circledR}$ DNA Blood $\left(\right.$ Qiagen $\left.^{\circledR}\right)$. Em 91 amostras não foram detectados vírus por nenhum dos métodos utilizados.

Os métodos de extração foram comparados de acordo com o descrito por Gordis (2004), que determina que a validade de um teste está diretamente associada a sua habilidade em distinguir pacientes doentes de não doentes, através de sua sensibilidade (habilidade em identificar corretamente pacientes doentes) e especificidade (habilidade em identificar corretamente pacientes não doentes).

Após aplicação das definições expostas acima, verificou-se que, quando comparado ao método MagMAX ${ }^{T M}$ Viral RNA Isolation (Ambiom), o método Qiaamp ${ }^{\circledR}$ DNA Blood (Qiagen $^{\circledR}$ ) apresentou sensibilidade de 54\%, mostrando-se menos eficiente na identificação das amostras positivas. A especificidade, no entanto, foi de $97,8 \%$, indicando que ambos os testes têm capacidade semelhante de identificar amostras negativas.

O valor preditivo positivo (VPP), que é a probabilidade de uma amostra, cujo teste foi positivo para a detecção de algum vírus, ser realmente positiva, foi avaliado em $75 \%$, e o valor preditivo negativo (VPN), que expressa a probabilidade de uma amostra, cujo teste foi negativo, ser realmente negativa foi de $94,8 \%$, sempre considerando os resultados obtidos através do método Qiaamp ${ }^{\circledR}$ DNA Blood (Qiagen ${ }^{\circledR}$ ) em relação ao MagMAX ${ }^{T M}$ Viral RNA Isolation (Ambiom), este último escolhido como método de referência para a comparação.

O índice de concordância observado entre os métodos de extração foi de $93 \%$ (obtido simplesmente através da análise do número de casos cujo resultado foi o mesmo para ambos os testes), mas o índice de concordância Kappa, que exclui os resultados obtidos ao acaso, foi de apenas 0,6, considerado intermediário ou razoável (GORDIS, 2004).

Embora o método Qiaamp ${ }^{\circledR}$ DNA Blood $\left(\right.$ Qiagen $\left.^{\circledR}\right)$ tenha sido apresentado em estudos anteriores como sendo de escolha para a extração de ácidos nucleicos virais a partir de amostras de líquor (SANTOS, 2009), o presente estudo concluiu que o método MagMAX $X^{T M}$ Viral RNA Isolation (Ambiom) apresenta maiores vantagens no que tange ao objetivo proposto. Além de ter se mostrado mais eficiente na extração dos ácidos nucleicos virais, o que ficou comprovado após a aplicação das definições estabelecidas por Gordis (2004), apresenta outras qualidades, ainda que secundárias, mas que devem ser consideradas quando se trata do diagnóstico clínico de rotina das infecções virais do SNC.

Como vantagens do método MagMAX ${ }^{T M}$ Viral RNA Isolation (Ambiom) podem ser citadas: utilização de menor quantidade de amostra clínica $(50 \mu \mathrm{L}$ x $200 \mu \mathrm{L}$ exigidos pelo Qiaamp ${ }^{\circledR}$ DNA Blood - Qiagen ${ }^{\circledR}$ ), fator importantíssimo quando se trata de materiais nobres como o líquor, nem sempre obtidos em grandes volumes; rapidez da reação, que consome 
cerca de 30 minutos para a extração de uma amostra, sendo possível a extração simultânea de 24 amostras sem aumento considerável do tempo requerido; processamento semiautomático, que exige do manipulador apenas a distribuição de amostras e reagentes na placa, sendo todas a etapas efetivas da extração realizadas pelo equipamento MagMAX ${ }^{\mathrm{TM}}$ Express (Applied Biosystems ${ }^{\circledR}$ ), simplificando muito o processo e reduzindo a chance de erros na execução da reação. Todos estes fatores contribuem para que este seja o método de escolha para uma possível aplicação no diagnóstico clínico de rotina das infecções virais do SNC.

As 273 amostras de líquor analisadas neste estudo foram extraídas através dos métodos discutidos acima, e o critério de escolha foi a disponibilidade do volume de amostra e dos reagentes no laboratório. Após este processo, as amostras foram submetidas às reações moleculares.

Visando à comparação entre as técnicas moleculares aplicadas neste estudo, vírus padrão e amostras clínicas foram extraídos e submetidos às reações de Nested-PCR, de acordo com o descrito por Santos (2009), e PCR em tempo real padronizada neste trabalho, para a detecção de adenovírus e enterovírus. Diluições de protótipos dos respectivos vírus foram submetidas simultaneamente às reações acima citadas.

No caso dos adenovírus, tanto a Nested-PCR quanto a PCR em tempo real foram capazes de detectar o DNA viral até à diluição $10^{-6}$. Verifica-se, ainda que de forma preliminar, que a sensibilidade das reações é equiparável, visto que apresentaram o mesmo limiar de detecção. Considerando-se as reações direcionadas aos enterovírus, verificou-se que o limiar de detecção da Nested-PCR foi superior ao da PCR em tempo real, sendo $10^{-7}$ e $10^{-6}$ respectivamente, sugerindo maior sensibilidade da primeira reação. Para validar a comparação dos resultados, as mesmas diluições de cada um dos vírus foram submetidas, de forma simultânea, às reações moleculares em questão.

Esperava-se que a reação de PCR em tempo real fosse mais sensível que a NestedPCR, o que não foi observado nas condições estabelecidas neste estudo. Por outro lado, tal fato pode ser indicativo de uma maior especificidade da PCR em tempo real. O ideal, no entanto, é a obtenção de reações sensíveis e específicas ao mesmo tempo.

Os conjuntos de oligonucleotídeos e sondas utilizados em cada uma das técnicas, embora destinados às mesmas regiões do genoma dos vírus estudados, apresentavam sequências diferentes, inclusive no que tange à presença de bases degeneradas. Portanto, as características a eles inerentes podem ter influenciado os resultados observados nas reações moleculares. 
Os oligonucleotídeos utilizados nas reações de Nested-PCR para adenovírus, por exemplo, apresentavam um número significativamente maior de bases degeneradas quando comparados aos utilizados na PCR em tempo real, o que pode ter contribuído para aumentar a sensibilidade da primeira reação. Em contrapartida, a PCR em tempo real pode ter sido influenciada pela maior especificidade dos primers e sonda utilizados. O ideal seria a utilização de iniciadores idênticos em cada uma das reações, de forma a excluir esta variável. Dessa forma, os resultados obtidos estariam mais intimamente associados às características particulares de cada técnica aplicada.

Convém ressaltar que os resultados observados constituem dados preliminares, e não definitivos. Seria necessária a utilização de um número estatisticamente significativo de amostras clínicas, além dos padrões, para validar a PCR em tempo real e realizar comparações sobre sua sensibilidade e especificidade, além da exclusão, como já mencionado, de todas as variáveis possíveis, de forma que os resultados venham a refletir apenas as características das reações moleculares. No entanto, devido a não disponibilidade de volume de líquor suficiente e possível degradação das amostras extraídas, apenas um pequeno número de amostras foi submetido a ambas as reações.

Duas amostras de líquor, previamente positivas pela Nested-PCR para a detecção de enterovírus, foram testadas pela PCR em tempo real, e sua positividade foi confirmada. Quanto aos adenovírus, foram testadas 5 amostras determinadas como positivas pela NestedPCR, e apenas 2 foram confirmadas pela segunda técnica. As amostras clínicas foram extraídas e testadas cerca de um ano antes pela Nested-PCR quando comparada à PCR em tempo real.

As amostras de líquor cuja positividade foi confirmada por ambas as técnicas apresentaram concentração de DNA bem mais elevada se comparadas àquelas com resultado positivo apenas pela Nested-PCR. Em geral, quando se trata de amostras de líquor, é esperada uma pequena quantidade de vírus, o que implica em pequena quantidade de material genético extraído.

Estudos indicam que, embora o DNA seja conhecido por sua estabilidade, quando se trata de amostras com pequena concentração deste ácido nucleico armazenadas por longos períodos de tempo, como no caso do presente estudo, pode haver degradação e adsorção das moléculas de DNA ao microtubo no qual estão armazenadas, neste caso, constituído de polipropileno. Tal observação pode justificar que amostras anteriormente positivas não tenham sido amplificadas pela PCR em tempo real. As oscilações de temperatura do freezer no qual estavam armazenadas as amostras extraídas também podem ter contribuído para o 
possível cisalhamento e degradação do DNA viral (BELOTSERKOVISKI; JOHNSTON, 1996; MELO et al., 2010; SMITH; MORIN, 2005).

Quando se trata do RNA, cuidados muito maiores devem ser observados. As amostras extraídas foram armazenadas a $-70^{\circ} \mathrm{C}$, mas as oscilações de temperatura do freezer e o tempo de armazenamento superior a um ano podem ter interferido de forma drástica na qualidade e quantidade do RNA armazenado (BELOTSERKOVISKI; JOHNSTON, 1996; MELO et al., 2010; SMITH; MORIN, 2005).

A correlação entre os resultados da titulação viral e da técnica de PCR em tempo real permitiu aferir que a reação molecular foi capaz de detectar um mínimo de 24 partículas infecciosas no caso dos enterovírus e menos que uma partícula infecciosa no caso dos adenovírus. Considerando-se os enterovírus, a facilidade de observação do efeito citopático torna o título calculado muito próximo ao número real de partículas virais infecciosas efetivamente contido na alíquota titulada, tornando válida a relação estabelecida e o limiar de detecção de 24 partículas observado na PCR em tempo real. No caso dos adenovírus, cuja observação do efeito citopático não é tão clara, o título viral calculado pode ser inferior ao real, e por isso o limiar obtido para a PCR em tempo real foi de menos que uma partícula infecciosa.

Das 273 amostras de líquor analisadas, colhidas de pacientes com suspeita de infecção do SNC atendidos no Hospital Universitário da USP, 40 (14,6\%) mostraram-se positivas após a realização da reação de Nested-PCR, sendo os adenovírus detectados em 2,5\% (7/273), os enterovírus em 9,8\% (27/273) e os herpesvírus dos tipos 1 e 2 em 1,1\% (3/273) das amostras. Coinfecções foram observadas em 3 casos: dois entre enterovírus e herpesvírus e um entre enterovírus e adenovírus.

Com relação aos enterovírus, muitos protocolos têm sido desenvolvidos, os quais são capazes de detectar, através de reações moleculares, a maioria dos sorotipos conhecidos, inclusive os não cultiváveis (CINQUE; BOSSOLASCO; LUNDIKVIST, 2003).

Os enterovírus são responsáveis pela maioria dos quadros de infecção viral do SNC, cerca de 80 a $90 \%$ dos casos. (IRANI, 2008; KUMAR, 2005; MacMAHON, 2008; SÃO PAULO, 2006). Em geral, estão associados a casos de meningite asséptica de leve a moderada, principalmente os echovírus e os coxsackievírus. Quadros mais graves, como encefalites, representam cerca de 3\% das infecções do SNC causadas por estes vírus (STAHL et al., 2011). Enterovírus dos sorotipos 71, 75, 76 e 89 foram associados a surtos de encefalite viral no sul da Ásia, Índia e regiões do Pacífico (HANDIQUE, 2011; TYLER, 2009). Enterovírus 71 tem sido reconhecido como o vírus neurotrópico mais importante desde a 
erradicação dos poliovírus em muitos países do mundo (WENG et al., 2010). Tais vírus foram identificados através de testes de neutralização em 40,8\% das 238 amostras de soro colhidas de pacientes atendidos no setor de Virologia do Instituto Evandro Chagas na cidade de Belém, Pará (GOMES et al., 2002).

Estudos realizados no Brasil têm detectado enterovírus associados a infecções do SNC em várias regiões do país. Em Belém, Gomes e colaboradores (2001) identificaram a presença destes vírus associados a quadros de meningite asséptica e deficiência motora através da reação de PCR em $60 \%$ das amostras testadas, todas coletadas de pacientes diagnosticados com algum tipo de alteração do SNC.

Em trabalho realizado na cidade de Salvador, Bahia, os enterovírus foram detectados através da técnica de PCR em 30,7\% das 91 amostras de líquor testadas, provenientes de pacientes com suspeita de meningite asséptica (SILVA et al., 2002). Vidal e colaboradores (2011), após analisarem 460 amostras de líquor provenientes de pacientes com meningite linfomonocitária atendidos na cidade de Curitiba (Paraná), através de técnicas de PCR, detectaram a presença de vírus em $12,8 \%$ das amostras, das quais $80 \%$ continham enterovírus.

Santos e colaboradores (2006) analisaram 1.022 amostras de líquor provenientes de pacientes de várias regiões do Brasil, colhidas durante períodos de surtos e em casos isolados de meningite viral ente os anos de 1998 a 2003. Os enterovírus foram detectados em 15,8\% das amostras, a grande maioria dos casos relacionados ao Echovírus 30, embora outros sorotipos também tenham sido identificados. $\mathrm{O}$ estudo confirmou cinco surtos de meningite viral durante o período de vigilância: quatro na região sul do país, Estados do Paraná e Rio Grande do Sul, e um na cidade de Recife (PE), nordeste do Brasil. Um surto de meningite asséptica causado pelo Echovírus 6 foi identificado em São Joaquim da Barra (SP), no ano de 2004 (LUCHS et al., 2008).

Na região metropolitana do Rio de Janeiro, entre março e maio de 2005, um surto de meningite asséptica associado aos enterovírus foi observado através do isolamento viral a partir de amostras de líquor e fezes, e o agente relacionado foi o Echovírus 30 (PINTO Jr, et al., 2009). Echovírus 30 foi, também, o sorotipo mais encontrado em casos de meningite asséptica no período de 1998 a 2008 no Brasil (SANTOS et al., 2011).

Em estudo conduzido na cidade de Ribeirão Preto (SP), 200 amostras de líquor de pacientes com suspeita de infecção do SNC foram analisadas entre 2003 e 2004. Os enterovírus foram detectados em 11,34\% das amostras (MENDOZA et al. 2007). Em trabalho realizado por Santos (2009) na cidade de São Paulo, 295 amostras de líquor foram testadas e os enterovírus detectados em $28 \%$ destas. Após sequenciamento das amostras positivas, a 
autora identificou uma grande variedade de sorotipos, sendo os Echovírus 18 e Coxsackievírus B5 os mais frequentemente encontrados.

Infecções causadas por enterovírus estão relacionadas a significativas taxas de morbidade em todo o mundo (RHOADES et al., 2011). Um estudo envolvendo nove centros de cinco países europeus analisou 476 amostras de líquor, detectando enterovírus em 14,4\% destas através da técnica de PCR (VLIET et al., 1998). Michos e colaboradores (2007) encontraram enterovírus em 48,9\% das amostras testadas por PCR em Atenas. Nos Estados Unidos, após análise de 1.374 amostras, 4,9\% apresentaram enterovírus (TAVAKOLI et al., 2008).

Quando comparado ao exposto pelos trabalhos acima citados, o número de enterovírus detectado no presente estudo foi um pouco menor que o encontrado pelos demais autores. Tal observação pode ser justificada pelos seguintes fatores: inclusão, neste trabalho, de amostras de líquor provenientes de pacientes de várias idades, não apenas crianças, faixa etária associada à maior ocorrência destas infecções (LUCHS et al., 2008); os diagnósticos de entrada relatados pelo clínico foram diversos, e não apenas de suspeita de infecção do SNC e a maioria das amostras de líquor analisadas apresentava perfil quimiocitológico normal, não indicativo de infecção viral. Conclui-se, portanto, que a amplitude das características das amostras incluídas nesta pesquisa, não observada nos demais estudos, nos quais as amostras analisadas estavam mais intimamente relacionadas a quadros de infecção do SNC, pode ter contribuído para a menor frequência não somente dos enterovírus, mas dos demais vírus estudados.

O sequenciamento dos enterovírus constitui ferramenta importante para a realização de estudos epidemiológicos que permitam o acompanhamento dos sorotipos circulantes e a detecção de surtos, mesmo que não alterem significativamente a conduta médica. No presente trabalho, como o objetivo principal foi o estabelecimento de métodos capazes de oferecer um diagnóstico rápido que possibilite orientar a conduta clínica nas infecções do SNC e não a determinação dos sorotipos circulantes, o sequenciamento não foi realizado.

Dentre os herpesvírus, vários são os tipos envolvidos em infecções do SNC, como mencionado anteriormente. Merecem destaque, no entanto, os herpesvírus dos sorotipos 1 e 2 , que constituem uma das principais causas de encefalite viral, cerca de 10 a $20 \%$ dos casos (TYLER, 2004; WHITLEY, 2006). A encefalite causada por herpesvírus, se não tratada, pode ser responsável por uma taxa de mortalidade de mais de $70 \%$, e apenas $11 \%$ dos pacientes que sobrevivem recuperam suas funções normais (SIMKO et al., 2002). 
Neste trabalho foi utilizada uma reação de Nested-PCR capaz de detectar os HHV-1 e HHV-2, simultaneamente, mas sem diferenciá-los. A seleção destes herpesvírus dentre os demais foi amparada pela sua maior frequência nas infecções do SNC, associada a quadros de elevada gravidade e taxa de mortalidade, como já mencionado. A inclusão de reações direcionadas à detecção dos demais herpesvírus, embora importante quando considerada a obtenção de um diagnóstico preciso para o paciente, agrega custos elevados e questionáveis, já que a frequência destes vírus como agentes das infecções do SNC é muito baixa (MENDOZA et al., 2007; SANTOS, 2009; STAHL et al., 2011).

Em estudo desenvolvido por Mendoza e colaboradores (2007), na cidade de Ribeirão Preto (SP), HHV-1 foram detectados em 5\% das amostras. Minjolle e colaboradores (2002), em trabalho desenvolvido na França, detectaram HHV-1 com uma frequência de 4,9\% na população estudada, enquanto HHV-2 foram encontrados em 1,4\% das amostras, num total de 6,3\% de positividade para ambos os vírus. Em estudo envolvendo 17 hospitais da Espanha, 566 amostras foram analisadas pela técnica de PCR, estando os HHV-1 presentes em 5,5\% das amostras e os HHV-2 em 0,5\%, num total 6\% das amostras analisadas (ORY et al., 2013). Em trabalho desenvolvido na Alemanha, 631 amostras de líquor foram analisadas, sendo HHV-1 e HHV-2 encontrados em $1,3 \%$ e $1,1 \%$ respectivamente, $2,4 \%$ no total. (SAUERBREI et al., 2000).

Com relação ao diagnóstico específico de encefalite herpética, definido através da observação de alterações neurológicas características e diagnóstico por imagem, Stahl e colaboradores (2011) avaliaram os resultados de estudos realizados em diversos países do mundo, incluindo Estados Unidos, Inglaterra, Japão, Finlândia, França e Grécia, no período compreendido entre 1967 e 2008. Os autores observaram, na grande maioria dos casos, a predominância dos HHV-1 e HHV-2, relacionados em geral, a mais de $10 \%$ das ocorrências. Nestes casos, as alterações neurológicas típicas da encefalite causada por herpesvírus foram consideradas, juntamente com o resultado da reação de PCR, para a determinação do diagnóstico final.

No presente trabalho, como citado anteriormente, foram detectados HHV-1 e HHV-2 (indistintamente) em 1,1\% das amostras de líquor analisadas. Se considerados os casos de coinfecção com outros vírus, esta porcentagem sobe para 1,8\%, abaixo do encontrado em outros trabalhos, ainda que a diferença observada não seja tão grande. Cabe ressaltar que muitas das amostras incluídas neste estudo não eram provenientes de pacientes com quadros de encefalite ou meningite previamente definidos. 
Um único resultado negativo para a reação de PCR não exclui totalmente a possibilidade de infecção pelos herpesvírus, principalmente se a amostra de líquor for colhida durante as primeiras 72 horas após o estabelecimento dos sintomas. O ideal é que o teste seja repetido no decorrer da doença (ELBERS; BITNUN; RICHARDSON, 2007). No presente estudo, apenas o quadro clínico inicial foi considerado, e por isso apenas a primeira amostra de líquor colhida foi analisada.

Outra questão a ser abordada é o efeito da terapia antiviral nos resultados das reações de PCR. Estudos realizados concluíram que a administração do aciclovir durante a primeira semana de tratamento não interfere na sensibilidade da técnica, podendo inclusive, facilitar a detecção do vírus devido à produção de altos níveis de fragmentos de DNA viral durante sua replicação na presença do medicamento. Quando com duração maior que uma semana, o tratamento pode sim afetar negativamente a sensibilidade da reação molecular (GUFFOND et al., 1994; THOMSON; BERTRAN, 2001; ZUNT; MARRA, 1999). Conclui-se que as reações de PCR são de fundamental importância para o acompanhamento da evolução dos quadros clínicos relacionados aos herpesvírus.

Cabe ressaltar a importância do diagnóstico rápido das infecções do SNC por herpervírus visto que, além da gravidade do quadro clínico a elas relacionado, existe a efetiva possibilidade de introdução da terapia antiviral, intervenção esta capaz de diminuir o aparecimento de sequelas em pacientes sobreviventes e reduzir, em até $20 \%$, os índices de mortalidade (SIMKO et al., 2002). Atualmente, na maioria dos casos, a introdução da terapia antiviral é baseada apenas na evolução clínica dos pacientes, e um diagnóstico molecular confiável e rápido poderia subsidiar tal decisão, possibilitando uma intervenção imediata e melhor fundamentada.

Os adenovírus humanos são responsáveis por diversas patologias, que acometem adultos e crianças, incluindo infecções respiratórias, oculares, gastrointestinais, urinárias e do SNC. As infecções do SNC causadas por adenovírus, embora não ocorram com grande frequência, incluem: meningites, mielites e encefalites (SINANIOTIS, 2004; STRAUSSBERG et al., 2001; TEBRUEGGE; CURTIS, 2012).

O primeiro relato de envolvimento dos adenovírus em infecções do SNC ocorreu em 1956 na França, quando durante um surto de infecção respiratória, cinco crianças apresentaram sintomas neurológicos, e o isolamento de adenovírus do sorotipo 7 a partir do líquor confirmou sua relação com o quadro de encefalite apresentado pelos pacientes. Desde então, casos esporádicos têm sido mencionados na literatura (STRAUSSBERG et al., 2001). Levy e colaboradores (1986) observaram manifestações clínicas associadas a infecções do 
SNC em três crianças infectadas por adenovírus do sorotipo 3. Ohtsuki e colaboradores (2000), relataram três casos de encefalopatia aguda associada ao adenovírus 7. Os adenovírus dos sorotipos 3 e 7 foram os mais frequentemente detectados em amostras de líquor provenientes de pacientes com suspeita de infecção do SNC em estudo desenvolvido por Santos (2009) na cidade de São Paulo, e são os mais intimamente associados a infecções respiratórias agudas graves. Neste mesmo estudo foram detectados adenovírus em 16\% de todas as amostras de líquor analisadas.

Em estudo desenvolvido em 1998 nos Estados Unidos, um caso de encefalite causada por adenovírus foi confirmado após o isolamento viral em cultura celular (ZAGARDO et al., 1998). Lema e colaboradores (2005) detectaram a presença de adenovírus em $5,5 \%$ das amostras de líquor analisadas, provenientes de pacientes com quadro de encefalite na Argentina. Dubberke e colaboradores (2006) relataram um caso inédito de meningoencefalite associada ao adenovírus do sorotipo 26 , e a detecção do vírus ocorreu através das técnicas de PCR e coloração imuno-histoquímica. Frange e colaboradores (2011) apresentaram dois casos de meningoencefalite em pacientes transplantados, com detecção dos adenovírus nas amostras de líquor através da reação de PCR.

No presente estudo, os adenovírus foram detectados em apenas 7 das 273 amostras de líquor analisadas $(2,5 \%)$ e em um caso de coinfecção com enterovírus. O pequeno número de adenovírus observado condiz com o apresentado em estudos realizados por outros autores, nos quais estes vírus foram detectados apenas de forma esporádica, quando associados às infecções do SNC. Em trabalho previamente realizado por Santos (2009) no Laboratório de Biologia molecular de Adenovírus do ICB-USP, no qual a autora detectou adenovírus em $16 \%$ das amostras de líquor analisadas, a inclusão das amostras no estudo foi muito mais seletiva, com a grande maioria dos pacientes atendidos e internados na clínica pediátrica, com diagnóstico inicial de meningite viral. No presente estudo, o universo das amostras analisadas seguiu a rotina apresentada pelo Laboratório de Análises Clínicas do HU-USP, e incluiu pacientes de várias idades e diversos quadros clínicos.

Considerando o exposto acima, fica claro que maiores estudos a respeito da associação entre os adenovírus e as infecções do SNC são necessários, principalmente no Brasil, voltados tanto para a avaliação da participação destes agentes virais nas infecções do SNC quanto para a determinação dos sorotipos mais frequentes. A elevada frequência observada destes vírus, principalmente em crianças, e a possível associação entre as infecções respiratórias agudas e as infecções do SNC, também justifica a necessidade de mais estudos. 
Três casos de coinfecção foram observados no presente trabalho. A associação de enterovírus e herpesvírus foi detectada em duas das amostras analisadas, enquanto em outra, enterovírus e adenovírus apareceram concomitantemente. Os dados disponibilizados pelo Hospital Universitário da USP para este estudo não faziam referência quanto ao estado imunológico dos respectivos pacientes, o que não nos permite associar coinfecção e imunossupressão. Outros estudos, no entanto, associam a presença de mais de um agente viral a pacientes imunodeprimidos (CHESKY et al., 2000; TANG et al. 1999), embora alguns casos não estejam associados à deficiência imunológica (CALVÁRIO et al., 2002).

Nas situações de coinfecção, é possível que um dos vírus seja o responsável pela ruptura da barreira hematoencefálica, enquanto a entrada do segundo agente viral ocorre de maneira oportunista (MENDOZA et al., 2007). É provável que a entrada dos enterovírus tenha ocorrido inicialmente, já que estes vírus causam infecções agudas e líticas, seguidos dos herpesvírus e adenovírus, que podem estar associados a infecções persistentes.

A coinfecção entre vírus e bactérias também foi relatada por outros autores, embora apresentada como ocorrência rara. A detecção de vírus não altera a conduta clínica direcionada ao tratamento da infecção bacteriana (CHESKY et al. 2000; PELKONEN et al., 2012; SANTOS, 2009), podendo apenas ser incluída a terapia antiviral quando indicada. No Brasil, a intervenção com antibioticoterapia é obrigatória em casos de suspeita de infecção bacteriana do SNC (BRASIL, 2010).

Com relação à distribuição mensal das amostras positivas, foi observada, no presente trabalho, uma predominância dos enterovírus entre fevereiro e abril de 2012, e novembro de 2012 e janeiro de 2013, períodos mais quentes do ano, embora também tenham sido detectados, com menor frequência, nos demais meses. Santos (2009), em estudo realizado também na cidade de São Paulo, identificou a predominância dos enterovírus no período de janeiro a março.

As infecções por enterovírus apresentam sazonalidade definida em regiões de clima temperado, ocorrendo em maior quantidade no verão e início do outono. Em países tropicais, no entanto, estes vírus podem ser observados durante todo o ano (CHADWICK, 2006; IRANI, 2008; LOGAN; MacMAHON, 2008). Richter e colaboradores (2006) relataram um surto ocasionado por enterovírus (echovírus sorotipos 30, 13 e 6) ocorrido na Bélgica durante o verão. Em estudo desenvolvido na Turquia, um surto de meningite asséptica associado ao echovírus 30 foi identificado nesta mesma estação (SENSOY et al., 2009).

No Brasil, a distribuição sazonal dos enterovírus não está bem definida, e a maioria dos estudos foi realizada em períodos epidêmicos. No entanto, em trabalho apresentado por 
Santos e colaboradores (2006), os resultados indicaram a ocorrência de surtos em cinco cidades, sendo três no Estado do Paraná, uma no Rio Grande do Sul e uma em Pernambuco. Embora o Brasil seja um país de clima tropical, sua extensão permite a observação de comportamentos climáticos variados.

Assim como no presente estudo, os surtos observados no Paraná e Rio Grande do Sul ocorreram durante os meses mais quentes (dezembro a março), já que nessas regiões é marcante a diferença de temperatura entre as estações. $\mathrm{O}$ surto observado em Pernambuco ocorreu entre os meses de abril e junho. No entanto, por ser uma região de clima tipicamente tropical, faz sentido que as infecções causadas por enterovírus sejam observadas durante todo o ano.

No presente trabalho, os adenovírus foram detectados nos meses de abril a setembro, nos quais a temperatura é mais baixa no Estado de São Paulo, coincidindo com o período de maior ocorrência das infecções respiratórias, constituindo mais um fator sugestivo da relação entre estas infecções e as do SNC associadas ao vírus em questão.

Com relação aos herpesvírus, não foi observada sazonalidade definida devido ao baixo número de amostras positivas, e não foram encontrados, na literatura pesquisada, dados que indiquem um comportamento sazonal destes vírus (STAHL, et al. 2011).

No que tange à faixa-etária dos pacientes em cujas amostras de líquor foi detectado algum dos vírus pesquisados neste estudo, foi observado que todas foram atingidas, embora as infecções tenham sido mais frequentemente encontradas em pacientes abaixo de 20 anos de idade, com discreta predominância em crianças com até 10 anos de idade. $\mathrm{O}$ número de indivíduos adultos atingidos, no entanto, foi muito significativo. Estudos realizados por outros autores indicam que as meningites virais, embora mais comuns em crianças, podem ocorrer em todas as idades (KUMAR, 2005; MENDOZA et al., 2007).

No presente trabalho, $44 \%$ das amostras nas quais foram detectados enterovírus pertenciam a pacientes com idade inferior a 10 anos. Adultos (acima de 20 anos) corresponderam a 33\% dos casos positivos para este vírus. Alguns autores afirmam que as infecções do SNC associadas aos enterovírus são mais comuns em crianças, principalmente aquelas em idade escolar, embora sejam frequentes também em adultos (CHADWICK, 2006; IRANI, 2008). Em trabalho realizado por Mendoza e colaboradores (2007), 50\% das infecções por enterovírus foram detectadas em adultos. Os dados obtidos no presente estudo reiteram os referidos por outros autores, destacando a importância destas infecções em todas as faixas etárias. 
Os herpesvírus do tipo 1 estão relacionados a casos de encefalite que atingem, principalmente, crianças e idosos. Aproximadamente um terço dos casos observados em pacientes de 6 meses a 20 anos de idade são consequência da infecção primária, enquanto a metade dos casos observados em pacientes com idade superior a 50 anos está relacionada a reativação viral. Os herpesvírus do tipo 2 causam, principalmente, encefalite neonatal através da infecção durante o parto (BULAKBASI; KOCAOGLU, 2008; LOGAN; MacMAHON, 2008). Em adolescentes e adultos as infecções por HHV-1 e HHV-2 são relatadas como sendo a segunda maior causa de meningite viral (DAMIANI; FURLAN; DAMIANI, 2012). No presente estudo, as 3 amostras de líquor nas quais foram detectados herpesvírus pertenciam a pacientes com idades de 19, 26 e 43 anos, sem considerar os casos de coinfecção, os quais ocorreram apenas em crianças.

Os adenovírus podem ser encontrados infectando pacientes de todas as faixas etárias, mas deve ser destacada sua importância como causadores de quadros de infecção respiratória aguda em crianças, o que pode pré-dispor a entrada do vírus no SNC. No presente trabalho, dos 6 casos encontrados de infecção por adenovírus (excluindo-se as coinfecções), 2 foram observados em crianças com menos de 1 ano de idade e os demais em jovens e adultos.

Com relação às coinfecções, todos os casos foram detectados em crianças, fato também observado em outros estudos (MENDOZA et al., 2007; SANTOS, 2009).

Os quadros clínicos dos pacientes incluídos neste trabalho foram definidos pelo médico responsável no momento do atendimento, e apresentaram-se através de relatos variados. Em 32\% dos casos analisados, o diagnóstico fazia referência a quadros de meningite e até mesmo meningite viral. Em outros $19 \%$ o médico utilizou, para a definição do quadro clínico, a sintomatologia apresentada pelo paciente, incluindo febre, cefaleia, confusão mental e convulsão. É interessante notar que todos os sintomas citados podem caracterizar quadros de infecção do SNC.

Outros diagnósticos como sepse, acidente vascular cerebral, choque, síndrome neonatal, pneumonia, sífilis, entre outros, foram descritos. A amplitude dos quadros clínicos dos pacientes cujas amostras foram analisadas neste estudo constitui uma das justificativas para o relativamente baixo número de amostras positivas detectadas, já que não houve a seleção apenas de pacientes com quadro clínico típico de infecção do SNC, como observado em outros trabalhos.

Dentre as amostras positivas observadas neste trabalho, $35 \%$ faziam parte do grupo previamente diagnosticado como meningite, e 25\% correspondiam aos pacientes cujos sintomas indicativos de infecção do SNC foram citados como quadros clínicos. Outro quadro 
clínico importante foi o de febre sem sinal localizatório (FSSL), observado em crianças com febre persistente e sem motivo aparente mesmo após cuidadoso exame físico, casos que corresponderam a 7,5\% das amostras positivas. O grupo denominado como "outros", foi responsável por $25 \%$ das amostras positivas, o que demonstra a importância do diagnóstico molecular na identificação de infecções do SNC mesmo quando a suspeita clínica não é tão clara.

Em outros casos referidos como encefalites, meningoencefalites e até mesmo dengue, nenhum dos vírus pesquisados foi encontrado. Considerando o exposto no início da discussão sobre a crescente importância dos flavivírus e alfavírus como causas de infecção do SNC, incluindo meningites e encefalites, fica clara a necessidade da introdução do diagnóstico molecular destinado à detecção destes agentes virais para maior esclarecimento das etiologias implicadas. É possível que no presente trabalho, bem como em outros estudos, nos quais os arbovírus não tenham sido pesquisados, tais vírus possam ser encontrados em meio às amostras ditas como negativas. No Brasil, trabalhos têm sido realizados com o intuito de identificar infecções do SNC relacionadas aos arbovírus, e alguns casos positivos já foram relatados (MONDINI et al., 2007; TERZIAN et al., 2011).

A análise quimiocitológica do líquor constitui uma das ferramentas mais utilizadas na prática clínica para a definição do diagnóstico das infecções do SNC. No caso das infecções bacterianas, a análise dos parâmetros químicos e citológicos do líquor associados à bacterioscopia e cultura, permite o fechamento do diagnóstico de forma satisfatória. Já no caso das infecções associadas a agentes virais, no entanto, a avaliação das características liquóricas é, muitas vezes, a única ferramenta laboratorial utilizada, visto que o isolamento viral em cultura celular é muito demorado e nem sempre viável, e as técnicas moleculares não estão amplamente disponíveis para as análises de rotina de um laboratório clínico. A questão é que, nem sempre, o líquor apresenta alterações típicas das infecções virais do SNC, o que não exclui a possibilidade de sua ocorrência, e o clínico acaba por determinar o diagnóstico de forma presuntiva, baseado nos sintomas clínicos do paciente e nas características epidemiológicas envolvidas.

No que tange à celularidade, apenas 97 das 273 amostras analisadas neste estudo apresentavam contagem celular acima do normal, e dentre estas, $24,7 \%$ apresentaram algum dos vírus pesquisados. Das 176 amostras com celularidade negativa, vírus foram detectados em $9,1 \%$. Pode ser observado que as chances de uma amostra com celularidade elevada conter vírus são maiores que as apresentadas por amostras com celularidade normal. Esta observação também foi descrita em outros trabalhos (MINJOLLE et al., 2002). No entanto, a ausência de 
pleocitose não exclui a possibilidade de haver infecção viral. Outros autores também detectaram a presença de vírus em amostras com contagem celular normal (CHOMAITREE; BALDWIN; LUCIA, 1989; MENDOZA et al., 2007).

Em líquores com presença de pleocitose, o predomínio de linfócitos está relacionado às infecções virais, o que nem sempre é observado na prática. $\mathrm{O}$ predomínio de células polimorfonucleares pode ser observado no início da infecção e durar por até 48 horas (BRASIL, 2010; LOGAN; MacMAHON, 2008; MENDOZA et al., 2007; MINJOLLE et al., 2002). No presente estudo, dentre as amostras positivas e com celularidade aumentada, em 54,2\% havia predomínio de linfócitos. Nas demais amostras a predominância de neutrófilos pode ser justificada, provavelmente, pela colheita do líquor nas primeiras horas da infecção viral. Minjolle e colaboradores (2002) também não observaram diferenças significativas nas amostras positivas no que diz respeito ao predomínio de um ou outro tipo celular.

Infecções do SNC estão associadas à elevação dos níveis de proteínas liquóricas, independentemente do agente etiológico envolvido. A hiperproteinorraquia é devida, geralmente, às alterações da barreira hematoencefálica ou à síntese intratecal de imunoglobulinas (DIMAS; PUCCIONI-SOHLER, 2008). No presente estudo, assim como descrito por outros autores, não foi possível estabelecer uma correlação clara entre a presença de vírus e a alteração dos níveis proteicos do líquor (MENDOZA et al., 2007; MINJOLLE et al., 2002).

A etiologia viral das infecções do SNC não está relacionada a alterações nos níveis de glicose do líquor. Os níveis normais correspondem a dois terços da glicose sérica, o que torna fundamental que a taxa de glicose sanguínea seja monitorada juntamente com a glicorraquia para que os resultados possam ser analisados (DIMAS; PUCCIONI-SOHLER, 2008). No presente estudo, os níveis de glicose das amostras positivas apresentaram-se normais de forma geral. Exceções importantes podem ser atribuídas a duas amostras positivas para herpesvírus, nas quais foram observados níveis de glicose diminuídos. Damiani e colaboradores (2002) relataram a possibilidade da ocorrência de hipoglicorraquia associada a infecções específicas do SNC causadas por herpesvírus dos tipos 1 e 2, denominadas meningites de Mollaret. Outros autores também associaram a infecção por herpesvírus a níveis de glicose normais ou levemente reduzidos (ALMEIDA, 2007).

Outros achados específicos, mas importantes, devem ser mencionados. No caso dos adenovírus, 6 das 8 amostras detectadas (incluindo coinfecções) apresentaram celularidade negativa. Outros autores também verificaram a ausência de pleocitose em amostras de líquor nas quais estes agentes virais foram identificados (STRAUSSBERG et al., 2001; ZAGARDO 
et al., 1998). Com relação aos herpesvírus, todas as amostras positivas detectadas, inclusive as coinfecções, correspondiam a líquores com celularidade bastante alterada (variando de 19 a 1.856 células $/ \mathrm{mm}^{3}$ ), $80 \%$ dos quais apresentavam predomínio de linfócitos. Um caso típico de infecção herpética do SNC foi relacionado a um paciente de 43 anos do sexo masculino, cujo quadro clínico mencionava um estado de confusão mental. A análise quimiocitológica do líquor detectou a presença de 229 células $/ \mathrm{mm}^{3}$, com $90 \%$ de linfócitos, proteínas aumentadas e glicose levemente baixa. Neste caso, a análise do líquor indicava a infecção viral, que foi confirmada, posteriormente, pela reação de Nested-PCR.

Fica claro que a definição do diagnóstico das infecções virais do SNC através apenas da análise quimiocitológica do líquor é insatisfatória na maioria dos casos. A utilização de outras metodologias para a confirmação da suspeita clínica é fundamental. Neste sentido, ratifica-se a importância do estabelecimento de métodos moleculares bem fundamentados, que possam efetivamente, realizar a detecção dos vírus nas amostras clínicas de líquor de forma confiável e rápida, visando ao fornecimento de dados que auxiliem o clínico na definição da conduta terapêutica do paciente.

As reações de Nested-PCR não são indicadas para a aplicação na rotina clínica, já que envolvem a manipulação de produtos de PCR, o que pode causar contaminação cruzada entre as amostras, reduzindo a confiabilidade dos resultados obtidos. No entanto, a etapa de reamplificação é necessária, já que o baixo número de partículas virais, geralmente associado às infecções do SNC, dificilmente é detectado após uma única reação de amplificação. A alternativa sugerida por este estudo é a introdução da técnica de PCR em tempo real, cuja sensibilidade é comparada à da Nested-PCR, porém sem a necessidade de manipulação de produtos pós-amplificação, já que toda a reação ocorre em sistema fechado.

A efetiva implantação da PCR em tempo real como diagnóstico complementar das infecções virais do SNC na rotina de um laboratório clínico, no entanto, requer a validação de todo o processo, desde a coleta das amostras de líquor, transporte, armazenamento, extração e aplicação das reações moleculares. O período que compreende todos os processos mencionados deve ser o menor possível, já que como citado anteriormente, há a possibilidade de degradação das amostras. Todos os reagentes, incluindo novos lotes, devem ser previamente testados com os protótipos virais a fim de garantir seu correto funcionamento, e os profissionais envolvidos devem ter total domínio das técnicas utilizadas.

A PCR em tempo real, cuja padronização foi iniciada neste estudo, constitui um passo importante para o estabelecimento de um método apto a ser aplicado como diagnóstico complementar das infecções virais do SNC na rotina de um laboratório clínico. É claro que a 
padronização e validação da técnica precisam ser concluídas, o que será providenciado em etapas futuras dando continuidade a este trabalho.

Os resultados apresentados e as questões discutidas neste estudo contribuem para a melhor compreensão das infecções virais do SNC, sua relação com os dados laboratoriais, achados epidemiológicos e alternativas diagnósticas, além de enfatizar a importância da efetiva implantação de um diagnóstico molecular aplicável à rotina de um laboratório clínico. Embora trabalhoso, este objetivo não deve ser esquecido, já que contribuirá de forma inquestionável para o melhor tratamento e bem-estar do paciente, que deve ser o foco principal das pesquisas desenvolvidas na área da saúde. 


\section{CONCLUSÕES}

Os enterovírus foram os vírus detectados com maior frequência nas amostras de líquor analisadas, assim como observado em estudos desenvolvidos por outros autores no Brasil e no mundo, seguidos pelos adenovírus e herpesvírus.

A extração das amostras de líquor através do método MagMAX ${ }^{T M}$ Viral RNA Isolation (Ambiom) mostrou-se mais eficiente e adequada à aplicação na rotina diagnóstica.

A presença de alterações nas características quimiocitológicas das amostras analisadas não constituiu fator determinante para a efetiva detecção dos vírus pesquisados, e a ausência destas alterações não excluiu a possibilidade da detecção de vírus no líquor.

Quanto à sazonalidade, foi observada uma maior frequência das infecções por enterovírus nos meses mais quentes do ano. As poucas amostras nas quais foram detectados adenovírus predominaram nos meses mais frios do ano. Não foi possível determinar relação de sazonalidade no caso dos herpesvírus.

Observou-se a distribuição dos vírus detectados em todas as faixas etárias, com predominância em pacientes abaixo dos 20 anos de idade.

Quanto às amostras nas quais foram detectados os vírus pesquisados neste estudo, $60 \%$ pertenciam a pacientes diagnosticados com meningite pelo clínico, ou que apresentavam sintomas indicativos da doença.

A PCR em tempo real constitui a alternativa mais adequada para a rotina diagnóstica de um laboratório clínico, devido a sua sensibilidade, especificidade, rapidez e reduzido risco de contaminação. As reações destinadas à detecção de adenovírus e enterovírus, cuja padronização foi iniciada neste estudo, são ferramentas importantes para o diagnóstico complementar das infecções virais do SNC, inclusive para a implantação na rotina de um laboratório clínico. A padronização definitiva e validação da técnica constituem as próximas etapas a serem realizadas, dando continuidade a este trabalho. 


\section{REFERÊNCIAS ${ }^{*}$}

ALMEIDA, S. M.; NOGUEIRA, M. B.; RABONI, S. M.; VIDAL, L. R. Laboratorial diagnosis of lymphocytic meningitis. Braz. J. Infect. Dis., v. 11, n. 5, p. 489-495, 2007.

AMERICAN TYPE CULTURE COLLECTIONTM - ATCC. VERO. Disponível em: <http://www.atcc.org/Products/All/CCL-81.aspx>. Acesso em: 28 jan. 2013.

AMERICAN TYPE CULTURE COLLECTIONTM - ATCC. HEK 293. Disponível em: <http://www.atcc.org/Products/All/CRL-1573.aspx>. Acesso em: 28 jan. 2013. .

ANDERSON, M. Management of cerebral infection. J. Neurol. Neurosurg. Psychiatry, v. 56, p. 1243-1258, 1993.

ATTIA, J.; HATALA, R.; COOK, D. J.; WONG, J. G. Does this adult patient has acute meningitis? JAMA, v. 282, n. 2, p. 175-181, 1999.

BEDOYA, S. P.; LEITE, J. P. G. Critérios diagnósticos das meningites virais. In: BEDOYA, S. P.; LEITE, J. P. G. Protocolos do laboratório de virologia comparada. Rio de Janeiro: FIOCRUZ, 1998. p. 3.

BELOTSERKOVSKII, B. P.; JOHNSTON, B. H. Polypropylene tube surfaces may induce denaluration and multimerization of DNA. Science, v. 271, p. 222-223, 1996.

BERGER, J. R.; HOUFF, S. Neurological complications of herpes simplex virus type 2 infection. Arch. Neurol., v. 65, n. 5, p. 596-600, 2008.

BERK, A. J. Adenoviridae: the viruses and their replication. In: KNIPE, D. M.; HOWLEY, P. M. Fields virology. $5^{\text {th }}$ ed. Philadelphia: Lippincott Williams \& Wilkins Publishers, 2007. p. 2355-2394.

BRASIL. Ministério da Saúde. Guia de vigilância epidemiológica. 7. ed. Brasília, 2010. 816 p.

BULAKBASI, N.; KOCAOGLU, M. Central nervous system infections of herpesvirus family. Neuroimag. Clin. N. Am., n. 18, p. 53-84, 2008.

BURNET, F. M.; WILLIAMS, S. W. Herpes simplex: new point of view. Med. J. Aust., v. 1, p. 637-640, 1939.

CALVÁRIO, A.; BOZZI, A.; SCARASCIULLI, M.; VENTOLA, C.; SECCIA, R.; STOMATI, D.; BRANCASI, B. Herpes Consensus PCR test: a useful diagnostic approach to the screening of viral diseases of the central nervous system. J. Clin. Virol., v. 25, p. S71-78, 2002. Suppl 1.

\footnotetext{
* De acordo com:

ASSOCIAÇÃO BRASILEIRA DE NORMAS TÉCNICAS. NBR 6023: informação e documentação: referências: elaboração. Rio de Janeiro, 2002.
} 
CASAS, I.; TENORIO, A.; ECHEVARRIA, J. M.; KLAPER, P, E.; ClEATOR, G, M. Detection of enteroviral RNA and specific DNA of herpesvirus by multiplex genome amplification. J. Virol. Methods, v. 66, p. 39-50, 1997.

CAVALCANTI, J. L. S. Meningites virais: enfermidades benignas? In: CAVALCANTI, J. L. S. Neuroinfecção. São Paulo: Ed. USP, 1994. p. 179-184.

CARVALHO, E. S. Meningites bacterianas na infância - atualização terapêutica. In: CARVALHO, E. S. Neuroinfecção. São Paulo: Ed. USP, 1994. p. 131-135.

CARVALHANAS, T. R. M. P.; BRANDILEONI, M. C. C.; ZANELLA, R. C. Meningites bacterianas. BEPA, ano 2, n. 17, p. 15-26, 2005.

CENTRO DE VIGILÂNCIA EPIDEMIOLÓGICA DO ESTADO DE SÃO PAULO. Disponível em: <http://www.cve.saude.sp.gov.br>. Acesso em: 29 abr. 2013.

CHADWICK, D. R. Viral meningitis. Br. Med. Bull., n. 75-76, p. 1-14, 2006.

CHAILERTVANITKUL, V. A.; POUTON, C. W. Adenovirus: a blueprint for non-viral gene delivery. Curr. Opin. Biotechnol., v. 21, n. 5, p. 627-632, 2010.

CHAKRABORT, S.; NAZMI, A.; DUTTA, K.; BASU, A. Neurons under viral attack: victimis or warriors? Neurochem. Int., v. 56, p. 727-735, 2010.

CHAMBON, M.; ARCHIMBAUD, C.; BAILLY, J. L.; HENQUELL, C.; REGAGNON, C.; CHARBONNÉ, F.; PEIGUE-LAFEUILLE, H. Circulation of enteroviruses and persistee of meningitis cases in the winter of 1990-2000. J. Med. Virol., v. 65, n. 2, p. 340-347, 2001.

CHESKY, M.; SCALCO, R.; FAILACE, L.; READ, S.; JOBIM, L. F. Polymerase chain reaction for the laboratory diagnosis of aseptic meningitis and encephalitis. Arq. Neuropsiquiatr., v. 58, n. 3-B, p. 836-842, 2000.

CHIRGWIN, J.; PRZYBYLA, A.; MACDONALD, A.; RUTTER, W. Isolation of biologically active ribonucleic acid from sources enriched in ribonuclease. Biochem., v. 18, n. 24, p. 5294-5299, 1979.

CHOMAITREE, T.; BALDWIN C. D.; LUCIA, H. L. Role of the virology laboratory in diagnosis and management of patients with central nervous system disease. Clin. Microbiol. Rev., v. 2, n. 1, p. 1-14, 1989.

CHOMCZYNSKY, P.; SACCHI, N. Single-step method of RNA isolation by acid guanidinium thiocyanate-phenol-chloroform extraction. Anal. Biochem., n. 162, p. 158, 1987.

CHRISTIE, A. B. Acute bacterial or pyogenic meningitis In: CHRISTIE, A. B. Infectius diseases: epidemiology and clinical practice. 3rd ed. Edinburg: Churchill Livingstone, 1969. p. 619-671. 
CINQUE, P.; BOSSOLASCO, S.; LUNDIKVIST, A. Molecular analysis of cerebrospinal fluid in viral diseases of the central nervous system. J. Clin. Virol., v. 26, p. 1-28, 2003.

COLIMON, R. Introduction to the virological diagnosis of the most frequent infections of the central nervous system. J. Clin. Virol., v. 25, p. S1-3, 2002. Suppl. 1.

COHEN, C. J.; SHIEH, J. T.; PICKLES, R. J.; OKEGAWA, T.; HSIEH, J. T.; BERGELSON, J. M. The coxsakievirus and adenovirus receptor is a transmembrane component of the tight junction. Proct. Natl. Acad. Sci. U. S. A., v. 18, n. 26, 15191-15196, 2001.

COMAR, S. R.; MACHADO, N. A.; DOZZA, T. C.; HASS, P. Análise citológica do líquido cefalorraquidiano. Estud. Biol., v. 31, n. 73-75, p. 93-102, 2009.

CRAWFORD-MIKSZA, L.; SCHNURR, D. P. Analysis of 15 adenovirus hexon proteins reveals the location and structure of seven hypervariable regions containing serotype-specific residues. J. Virol,. V. 70, p. 1836-1844, 1996.

DA COSTA, X. J.; KRAMER, M. F.; ZHU, J.; BROCKMAN, M. A.; KNIPE, D. M. Construction, phenotypic analysis, and immunogenicity of a UL5/UL29 double deletion mutant of herpes simplex virus 2. J. Virol., v. 74, p. 7963-7971, 2000.

DAMIANI, D.; FURLAN, M. C.; DAMIANI, D. Meningite asséptica. Rev. Bras. Clin. Med., v. 10, n. 1, p. 46-50, 2012.

DEPARTAMENTO DE INFORMÁTICA DO SISTEMA ÚNICO DE SAÚDE (DATASUS). Informações de saúde. Disponível em <http://www.datasus.gov.br>. Acesso em: 29 abr. 2013.

DE VRIES, H. E.; KUIPER, J.; DE BOER, A. G.; VAN BERKEL, T. J. C.; BREIMER, D. D. The blood-brain barrier in neuroinflamatory diseases. Pharmacol. Rev., v. 49, p. 143-155, 1997.

DIEFENBACH, R. J.; MIRANDA SAKSENA, M.; DOUGLAS, M. W.; CUNNINGHAM, A.L. Transport and egresso f herpes simplex virus in neurons. Rev. Med. Virol., n. 18, p. 35$51,2008$.

DIMAS, L. F.; PUCCIONI-SOHLER, M. Exame do líquido cefalorraquidiano: influência da temperatura, tempo e preparo da amostra na estabilidade analítica. Bras. Patol. Med. Lab., v. 44, n. 2, p. 97-106, 2008.

DORIAN, B. M.; KANG, S. S. Illuminating viral infections in the nervous system. Nat. Rev. Immunol., v. 11, p. 318-329, 2011.

DRAGO, L.; LOMBARDI, A.; DE VECCHI, E.; GIULIANI, G.; BARTOLONE, R.; GISMONDO, M.R. Comparision of nested PCR and real time PCR of hepesvirus infections of central nervous system in HIV patients. BMC Infect. Dis., v. 4, p. 55-60, 2004.

DUBBERKE, E. R.; TU, B.; RIVET, D. J.; STORCH, G. A.; APISARNTHANARAK, A.; SCHMIDT, R. E.; WEISS, S.; POLISH, L. B. Acute meningoencephalitis caused by adenovirus serotype 26. J. Neurovirol., v. 12, n. 3, p. 235-240, 2006. 
ELBERS, J. M.; BITNUN, A.; RICHARDSON, S. E. A 12 year prospective study of childhood herpes simplex encephalitis: is there a broader spectrum of disease? Pediatrics, v. 119, n. 2, p. 399-407, 2007.

ENDERS, J. F.; BELL, J. A.; DINGLE, J. H.; FRANCIS, T, Jr, HILLEMAN, M. R.; HUEBNER, R. J.; PAYNE, A. M. Adenoviruses: Group named proposed for new respiratory tract viruses. Science, v. 124, p. 119-120, 1956.

FIGUEIREDO, L. T. M. The Brazilian flaviviruses. Microbes and Infection, v. 2, p. 1643$1649,2000$.

FRANGE, P.; LATOUR, R. P.; ARNAUD, C.; BODDAERT, N.; OUALHA, M.; AVETTAND-FENOEL, V.; BERNAUDIN, F.; AGUILAR, C.; BARNERIAS, C.; LERUEZVILLE, M.; TOUZOT, F.; LORTHOLARY, O.; FISCHER, A.; BLANCHE, S. Adenoviral Infection Presenting as an Isolated Central Nervous System Disease without Detectable Viremia in Two Children after Stem Cell Transplantation J. Clin. Microbiol., v. 49, n. 6, p. 2361-2364, 2011.

GOMES, M. L. C.; KOPECKA, H.; LINHARES, A. C. Detection of enteroviruses in cases of neurological disorders in the state of Pará, Brazil. Rev. Inst. Med. Trop. S. Paulo, v. 43, n. 6, p. 321-324, 2001.

GOMES, M. L. C.; CASTRO, C. M. O.; OliveIRA, M. J. C.; SILVA, E. E. Neutralizing antibodies to enterovirus 71 in Belém, Brazil. Mem. Inst. Oswaldo Cruz, v. 97, n. 1, p. 4749, 2002.

GORDIS, L. Avaliação da validade e da confiabilidade dos testes diagnósticos e de rastreamento. In: Epidemiologia. 2. ed. Rio de Janeiro: Revinter, 2004. p. 63-81.

GREENWOOD, B. Editorial: 100 years of epidemic meningitis in West Africa - has anything changed? Trop. Med. Int. Health, v. 11, n. 6, p. 773-780, 2006.

GRIFFIN, D. E. Alphaviruses; In: KNIPE, D. M.; HOWLEY, P. M. Fields virology. $5^{\text {th }}$ ed. Philadelphia: Lippincott Williams \& Wilkins Publishers, 2007. p. 1023-1068.

GRIMWOOD, K.; CARZINO, R.; BARNES, G. L.; BISHOP, R. F. Patients with enteric adenovirus gastroenteritis admitted to an Australian pediatric teaching hospital from 1981 to 1992. J. Clin. Microbiol., v. 33, p. 131-136, 1995.

GUBLER, D.; KUNO, G.; MARKOFF, L. Flaviviruses; In: KNIPE, D. M.; HOWLEY, P. M. Fields virology. $5^{\text {th }}$ ed. Philadelphia: Lippincott Williams \& Wilkins Publishers, 2007. p. 1153-1252.

GUFFOND, T.; DEWILDE, A.; LOBERT, P. E.; CAPARROS-LEFEBVRE, D.; HOBER, D.; WATTRE, P. Significance and clinical relevance of the detection of herpes simplex virus DNA by the polymerase chain reaction in cerebrospinal fluid from patients with presumed encephalitis. Clin. Infect. Dis., v. 18, n. 5, p. 744-749, 1994.

GUPTA, R. K.; SONI, N.; KUMAR, S.; KHANDELWAL, N. Imaging of central nervous system viral diseases. J. Magn. Reson. Imaging, n. 35, p. 477-491, 2012. 
HANDIQUE, S. K. Viral infections of the central nervous system. Neuroimag. Clin. N. Am., v. 21, p. 777-794, 2011.

HEID, C. A.; STEVENS, J.; LIVAK, K. J.; WILLIAMS, P. M. Real time quantitative PCR. Genome Res., v. 6, n. 10, p. 986-994, 1996.

HILLEMAN, M. R.; WERNER, J. H. Recovery of new agent from patients with acute respiratory illness. Proc. Soc. Exp. Biol. Med., v. 85, p. 1983-1988, 1954.

HOGLE, J. M.; CHOW, M.; FILMAN, D. J. Three-dimensional structure of poliovirus at 2.9 A resolution. Science, v. 27, n. 229, p. 1358-1365, 1985.

HOSOYA, M.; HONZUMI, K.; SATO, M.; KATAYOSE, M.; KATO, K.; SUZUKI, H. Application of PCR for various neurotropic viruses on the diagnosis of viral meningitis. $\mathbf{J}$. Clin. Virol., v. 20, n. 11, p. 117-124, 1998.

IKEDA, Y.; YAMAOKA, K.; NODA, M.; OGINO, T. Genome types of adenovírus type 7 isolated in Hiroshima city. J. Med. Virol., v. 69, p. 215-219, 2003.

INVITROGEN. TaqMan® Chemistry vs. SYBR® Chemistry for Real-Time PCR. Disponível em: <http://www.invitrogen.com>. Acesso em: 21 de jan. 2013.

INTERNATIONAL COMMITTEE ON TAXONOMY OF VIRUSES. Virus databases. Disponível em: < http://ictvonline.org>. Acesso em: 10 jan. 2013.

IRANI, D. N. Aseptic meningitis and viral myelitis. Neurol. Clin., v. 26, n. 3, p. 635-viii, 2008.

JEFFERY, K. J.; READ, S. J.; PETO, T. E. A.; MAYON-WHITE, R. T.; BANGHAM, C. R. M. Diagnosis of viral infections of the central nervous system: clinical interpretation of PCR results. The Lancet, v. 349, p. 313-317, 1997.

JIANG, S. C. Human adenovirus in water: occurrence and health implications: acritical review. Environ. Sci. Technol., v. 40, p. 7132-7140, 2006.

JOHANSON, C. E.; DUNCAN III, J. A.; KLINGE, P. M.; BRINKER, T.; STOPA, E. G.; SILVERBERG, G. D. Multiplicity of cerebrospinal fluid functions: new challenges in health and disease. Cerebrospinal Fluid Res., v. 5, p. 10-42, 2008.

JOTHIKUMAR, N.; CROMEANS, T. L.; HILL, V. R.; LU, X.; SOBSEY, M. D.; ERDMAN, D. D. Quantitative real-time PCR assays for detection of human adenoviruses and identification of serotypes 40 and 41. Appl. Envirom. Microbiol., v. 71, n. 6, p. 3131-3136, 2005.

KUMAR, R. Aseptic meningitis: Diagnosis and management. Indian J. Pediatr., v. 72, n. 1, p. 57-63, 2005.

LEMA, C. L.; CISTERNA, D. M.; FREIRE, M. C. Neurologic disease due to adenovirus infection. Medicina (B. Aires), v. 65, n. 3, p. 196-200, 2005. 
LENNETT, E. H.; SCHIMIDT, N. J. Diagnostic procedures for viral, ricketsial, and chlamydial infections. Washington, DC: American Public Health Association, 1979. p. 229249.

LEVY, Y.; NITZAN, M.; BEHARAB, A. Adenovirus type 3 infection with systemic manifestation in apparently normal children. Isr. J. Med. Sci., v. 22, p. 774-778, 1986.

LIN, K.; SÀ, P. N. D. Aspectos farmacocinéticos e farmacodinâmicos dos agentes antibacterianos no sistema nervoso central. Arq. Cat. Med., v. 31, n. 1-2, p. 25-30, 2002.

LOGAN, S. A. E.; MacMAHON, E. Viral meningitis. Br. Med. J., v. 336, p. 36-40, 2008.

LU, X.; ERDMAN, D. D. Molecular typing of human adenoviruses by PCR and sequencing of a partial region of the hexon gene. Arch. Virol., v. 151, p. 1587-1602, 2006.

LUCHS, A.; RUSSO, D. H.; CILLI, A.; COSTA, F. F.; MORILLO, S. G.; MACHADO, B. C.; PELlini, A. C. G.; CARMONA, R. C. C.; TIMENETSKY, M. C. S. T. Echovirus 6 associated to aseptic meningitis outbreak, in São Joaquim da Barra, São Paulo, Brazil. Braz. J. Microbiol., v. 39, p. 28-31, 2008.

LUPI, O.; SILVA, A. G.; PEREIRA Jr, A. C. Epidemiologia dos herpesvirus. In: LUPI, O.; SILVA, A. G.; PEREIRA Jr, A. C. Herpes: clínica, diagnóstico e tratamento. Rio de Janeiro: Médici, 2000. p. 15-32.

LUPI, O.; SILVA, A. G.; PEREIRA Jr, A. C. Herpes simples genital: uma pandemia. An. Bras. Dermatol., v. 71, n. 1, p. 59-61, 1996.

McGAVERN, D. B.; KANG, S. S. Illuminating viral infections in the central nervous system. Nature Rev. Immunol., v. 11, p. 318-329, 2011.

MagMAX $^{\mathrm{TM}}$ Viral RNA Isolation. Kit instruction manual. Ambion, 2008. 15 p.

MARKOULATOS, P.; GEORGOPOLOU, A.; SIAFAKAS, N.; PLAKOKEFALOS, E.; TZANAKI, G.; KOUREA-KREMASTINOU, J. Laboratory diagnosis of common herpesvirus infection of the central nervous system by a multiplex PCR assay. J. Clin. Microbiol., v. 39, n. 12, p. 4426-4432, 2001.

MELO, M. R.; MARTINS, A. R.; BARBOSA, I. V.; ROMANO, P.; SHCOLNIK, W. Collection, transport and storage of samples for molecular diagnosis. J. Bras. Patol. Med. Lab., v. 46, n. 5, p. 375-381, 2010.

MENDOZA, L. P.; BRONZONI, R. V. M.; TAKAYANAGUI, O. M.; AQUINO, V. H.; FIGUEIREDO, L. T. M. Viral infections of the central nervous system in Brasil. J. Infect., n. 54, p. 589-596, 2007.

METTENLEITER, T. C. Pathogenesis of neurotropic herperviruses: hole of viral glycoproteins in neuroinvasion and transneuronal spread. Virus Res., v. 92, n. 2, p. 197-206, 2002. 
MICHOS, A. G.; SYRIOPOULOU, V. P.; HADJICHRISTODOULOU, C.; DAIKOS, G. L.; LAGONA, E.; DOURIDAS, P.; MOSTROU, G.; THEODORIDOU, M. Aseptic meningitis in children: Analysis of 506 Cases. PLoS ONE, v. 2, n. 8, p. 674-679, 2007.

MINJOLLE, S.; ARVIEUX, C.; GAUTIER, A. L.; JUCELIN, I.; THOMAS, R.; MICHELET, C.; COLIMON, R. Detection of herpesvirus genomes by polymerase chain reaction in cerebrospinal fluid and clinical findings. J. Clin. Virol., n. 25, p. S59-S70, 2002.

MONDINI, A.; CARDEAL, I. L. S.; LÁZARO, E.; NUNES, S, H.; MOREIRA, C. C.; RAHAL, P.; MAIA, I. L.; FRANCO, C.; GÓNGORA, D. V.; GÓNGORA-RUBIO, F.; CABRERA, E. M.; FIGUEIREDO, L. T.; DA FONSECA, F. G.; BRONZONI, R. V.; CHIARAVALLOTI-NETO, F.; NOGUEIRA, M. L. 1. Saint Louis encephalitis virus. Brazil Emerg. Infect. Dis., v. 13, n. 1, p. 176-178, 2007.

MULLIS, K. B. Target amplification for DNA analysis by the polymerase chain reaction. Ann. Biol. Clin., v. 48, n. 8, p. 579-582, 1990.

NAHMIAS A. J.; LEE, F. K.; BECKMAN-NAHMIAS, S. Soroepidemiological and sociological patterns of herpes simplex virus infection in the word. Scan. J. Infect. Dis., n. 69, p. 19-36, 1990.

OBERSTE, M. S.; PALLANSCH, M. A. Establishing evidence for enterovirus infection in chronic disease. Ann. N. Y. Acad. Sci., v. 1005, p. 23-31, 2003.

OHTSUKI, N.; KIMURA, S.; NEZU, A. Three cases with acute encephalopathy related with adenovirus type 7 infection. No. To. Hattatsu., v. 32, p. 68-72, 2000.

ORGANIZAÇÃO MUNDIAL DE SAÚDE. Data and statistics. Disponível em: <http://www.who.int/en>. Acesso em: 25 ago. 2012.

ORY, F.; AVELLÓN, A.; ECHEVARRÍA, J. E.; SÁNCHEZ-SECO, M. P.; TRALLERO, G.; CABRERIZO, M.; CASAS, I.; POZO, F.; FEDELE, G.; VICENTE, D.; PENA, M. J.; MORENO, A.; NIUBO, J.; RABELLA, N.; RUBIO, G.; PÉREZ-RUIZ, M.; RODRÍGUEZIGLESIAS, M.; GIMENO, C.; EIROS, J. M.; MELÓN, S.; BLASCO, M.; LÓPESMIRAGAYA, I.; VARELA, E.; MARTINEZ-SAPIÑA, A.; RODRÍGUEZ, G.; MARCOS, M. A.; GEGÚNDEZ, M. I.; SILLAS, G.; GABILONDO, I.; NAVARRO, J. M.; TORRES, J.; AZNAR, C.; CASTELLANOS, A.; GUISASOLA, M. E.; NEGREDO, A. I.; TENORIO, A.; VÁZQUEZ-MORÓN, S. Viral infections of the central nervous system in Spain: a prospective study. J. Med. Virol., n. 85, p. 554-562, 2013.

PALLANSCH, M.; ROOS, R. Enteroviruses: poliovirus, coxsackievirus, echovirus, end newer enterovirus. In: KNIPE, D. M.; HOWLEY, P. M. Fields virology. $5^{\text {th }}$ ed. Philadelphia: Lippincott Williams \& Wilkins Publishers, 2007. p. 840-884.

PELKONEN, T.; ROINE, I.; ANJOS, E.; KAIJALAINEN, S.; ROIVAINEN, M.; PELTOLA, H.; PITKÄRANTA, A. Picornaviruses in cerebrospinal fluid of children with meningitis in Luanda, Angola. J. Med. Virol., v. 84, n. 7, p. 1080-1083, 2012. 
PINTO Jr, V. L.; REBELO, M. C.; COSTA, E. V.; SILVA, E. E.; BÓIA, M. N. Description of a widespread outbreak of aseptic meningitis due to echovirus 30 in Rio de Janeiro State, Brazil. Braz. J. Infect. Dis., v. 13, n. 5, p. 367-370, 2009.

POLAGE, C. R.; PETTI, C. A. Assessment of the utility of viral culture of cerebrospinal fluid. Clin. Infect. Dis., v. 43, p. 1578-1579, 2006.

PUBLIC HEALTH ENGLAND CULTURE COLLECTION. Disponível em <http://www.hpacultures.org.uk>. Acesso em: 7 maio 2013.

QIAAMP $^{\circledR}$ DNA Mini and Blood. Mini Handbook. $2^{\text {nd }}$ ed. QIAGEN, 2007. 72 p.

RACANIELLO, P. R. Picornaviridae: the viruses and their replication. In: KNIPE, D. M.; HOWLEY, P. M. Fields virology. $5^{\text {th }}$ ed. Philadelphia: Lippincott Williams \& Wilkins Publishers, 2007. p. 796-837.

RICHTER, J.; KOPTIDES, D.; TRYFONOS, C.; CHRISTODOULOU, C. Molecular typing of enteroviruses associated with viral meningitis in Cyprus, 2000-2002. J. Med. Microbiol., n. 55, p. 1035-1041, 2006.

RHOADES, R. E.; TABOR-GODWIN, J. M.; TSUENG, G.; FEUER, F. Enterovirus infections of the central nervous system. Review. Virology, v. 411, n. 2, p. 288-305, 2011.

ROIZMAN, B.; KNIPE, D. M.; WHITLEY, R. J. Herpes simplex viruses; In: KNIPE, D. M.; HOWLEY, P. M. Fields virology. $5^{\text {th }}$ ed. Philadelphia: Lippincott Williams \& Wilkins Publishers, 2007. p. 2502-2601.

ROOS, K. L.; Viral meningitis. In: ROOS, K. L. Principles of neurologic infectious diseases. New York: McGraw-Hill Professional, 2005. p. 55-65.

ROTBART, H. A. Enteroviral infections of the central nervous system. Clin. Infect. Dis., v. 20, n. 4, p. 971-981, 1995.

ROWE, W. P.; HUEBNER, R. J.; GILMORE, L. K.; PARROT, R. H.; WARD, T. G. Isolation of a cytopathogenic agente from human adenoids undergoing spontaneous degeneration in tissue culture. Proc. Soc. Exp. Biol. Med., v. 84, p. 570-573, 1953.

RUSSEL, W. C. Update on adenovirus and its vectors. J. Gen. Virol., v. 81, p. 2573-2605, 2000 .

SALINAS, S.; SCHIAVO, G.; KREMER, E. J. A hitchhiker's guide to the nervous system: the complex journey of viroses and toxins. Nature Rev. Microbiol., v. 8, p. 645-655, 2010.

SANTOS, G. P. L.; OLIVEIRA, I. S. D.; LIMA, A. A. F.; MELO, M. M. M.; KMETZSCH, C. I.; COSTA, E. V.; SILVA, E. E. enterovirus meningitis in Brasil, 1998-2003. J. Med. Virol., n. 78, p. 98-104, 2006.

SANTOS, D. C. Estabelecimento de métodos moleculares para aplicação no diagnóstico rápido de vírus neurotrópicos. 2009. $175 \mathrm{f}$. Tese (Doutorado em Microbiologia) - Instituto de Ciências Biomédicas, Universidade de São Paulo, São Paulo, 2009. 
SANTOS, G. P.; COSTA, E. V; TAVARES, F. N.; COSTA, L. J.; SILVA, E. E. Genetic diversity of Echovirus 30 involved in aseptic meningitis cases in Brazil (1998-2008). J. Med. Virol., v. 83, n. 12, v. 2164-2171, 2011.

SÃO PAUlO. Secretaria de Estado da Saúde. Meningites virais. Rev. Saúde Pública, v. 40, n. 4, p. 748-750, 2006.

SAUERBREI, A.; EICHHORN, U.; HOTTENROTT, G.; WUTZLER, P. Virological diagnosis of herpes simplex encephalitis. J. Clin. Virol., n. 17, p.31-36, 2000.

SCHNEWEISS, K. E. Untersuchungen zur typendifferenzierung des herpesvirus hominis. Z. Immuno-Forsch, v. 124, p. 24-28, 1962.

SCHREIBER, W.; MATHYS, F. K. Meningite epidêmica In: SCHREIBER, W.; MATHYS, F. K. Infection: doenças infecciosas na história da medicina. Basiléia, Editiones <Roche>, 1991. p. 113-232.

SENSOY, G.; SEL, K.; OZKAYA, E.; CAKIR, B. C.; VIDINLISAN, S.; DOGANCI, L. Enteroviral meningitis in children in Turkey. Cent. Eur. J. Med., v. 4, n. 2, p. 253-258, 2009.

SILVA, H. R.; TANAJURA, G. M.; TAVARES-NETO, J.; GOMES, M. L. C.; LINHARES, A. C.; VASCONCELOS, P. F. C.; KO, A. I. Síndrome da meningite asséptica por enterovírus e Leptospira sp em crianças de Salvador, Bahia. Rev. Soc. Bras. Med. Trop., v. 35, n. 2, p. 159-165, 2002.

SIQUEIRA-SILVA, J.; YEDA, F. P.; FAVIER, A. L.; MEZIN, P.; SILVA, M. L.; BARRELLA, K. M.; MEHNERT, D. U.; FENDER, P.; HÁRSI, C. M. Infection kinetics of human adenovirus serotype 41 in HEK 293 cells. Mem. Inst. Oswaldo Cruz, v. 104, n. 5, p. 736-744, 2009.

SKIPOR, J.; THIERRY, J. The choroid plexus - cerebrospinal fluid system: undervaluated pathway of neuroendocrine signaling into the brain. Acta. Neurobiol. Exp., v. 68, n 3, p. 414$428,2008$.

SIMKO, J. P.; CALIENDO, A. M.; HOGLE, K.; VERSALOVIC, J.; Differences in laboratory findings for cerebrospinal fluid specimens obteined from patients with meningitis or encephalitis due two Herpes simplex virus (HSV) documented by detection of HSV DNA. Cin. Infect. Dis., v. 35, p. 414-419, 2002.

SMITH, S.; MORIN, P. A. Optimal Storage Conditions for Highly Dilute DNA Samples: A Role for Trehalose as a Preserving Agent. J. Forensic Sci., v. 50, n. 5, p. 1-8, 2005.

SINANIOTIS, C. A. Viral pneumoniae in children: incidence and aetiology. Pediatric Resp. Rev., n. 5, p. 197-200, 2004.

SOMAND, D.; MEURER, W. Central nervous system infections. Emerg. Med. Clin. N. Am., v. 27, p. 89-100, 2009.

STAHL, J. P.; MAILLES, A.; DACHEUX, L.; MORAND, P. Epidemiology of viral encephalitis in 2011. Med. Mal. Infect., v. 41, p. 453-464, 2011. 
STANNARD, L. M. Virus ultrastructure: Adenovirus. Disponível em: <http://web.uct.ac.za/depts/mmi/stannard/emimages.html>. Acesso em: 20 jan. 2013.

STANNARD, L. M. Virus ultrastructure: Herpesvirus. Disponível em: <http://web.uct.ac.za/depts/mmi/stannard/emimages.html>. Acesso em: 20 jan. 2013.

STRAUSSBERG, R.; HAREL, L.; LEVY, Y.; AMIR, J. A syndrome of transient encephalopathy associated with adenovirus infection. Pediatrics, v. 107, n. 5, p. 69-72, 2001.

STORCH, G. A. Diagnostic virology. In: KNIPE, D. M.; HOWLEY, P. M. Fields virology. $5^{\text {th }}$ ed. Philadelphia: Lippincott Williams \& Wilkins Publishers, 2007. p. 565-604.

TANG, Y. W.; HIBBS, J. R.; TAU, K. R.; QIAN, Q.; SKARHUS, H. A.; SMITH, T. F.; PERSING, D. H. Effective use of polymerase chain reaction for diagnosis of central nervous system infections. Clin. Infect. Dis., v. 29, n. 4, p. 803-806, 1999.

TAVAKOLI, N. P.; WANG, H.; NATTANMAI, S.; DUPUIS, M.; FUSCO, H.; HULL, R. Detection and typing of enteroviruses from CSF specimens from patients diagnosed with meningitis/encephalitis. J. Clin. Virol., v. 43, n. 2, p. 207-211, 2008.

TEBRUEGGE, M.; CURTIS, N. Adenovirus: an overview for pediatric infectious diseases specialists. Pediatr. Infect. Dis. J., v. 31, n. 6, p. 626-627, 2012.

TERZIAN, A. C. B.; MONDINI, A.; BRONZONI, R. V. M.; DRUMOND, B. P. ; FERRO, B. P.; CABRERA, E. M. S.; FIGUEIREDO, L. T. M.; CHIRAVALLOTI, N. F.; NOGUEIRA, M. L. Detection of St. Louis encephalitis virus in dengue suspected cases during a dengue 3 outbreak. Vector Borne Zoonotic. Dis., v. 11, p. 291-300, 2011.

THOMSON, R. B.; BERTRAM, H. Laboratory diagnosis of central nervous system infections. Infect. Dis. Clin. N. Am., v. 15, n. 4, p. 1047-1071, 2001.

TOLLEFERSON, A. E.; RIERSE, J. S.; SCARIA, A.; HERMISTON, T. W.; WOLD, W. S. The E3-11.6-kDa adenovirus death protein (ADP) is required for efficient cell death: characterization of cells infected with ADP mutants. Virology, v. 220, p. 175-162, 1996.

TYLER, K. L. Herpes simplex virus infections of the central nervous system: encephalitis and meningitis, including Mollaret's. Herpes, v. 11, p. 57A-64A, 2004. Suppl 2.

TYLER, K. L. Emerging viral infections of the central nervous system: part 1. Arch. Neurol., v. 66, n. 8, p. 939-948, 2009.

VIDAL, L. R. R.; ALMEIDA, S. M.; MESSIAS-REASON, I. J.; NOGUEIRA, M. B.; DEBUR, M. C.; PESSA, L. F. C.; PEREIRA, L. A.; ROTTA, I.; TAKAHASHI, G. R. A.; SILVEIRA, C. S.; ARAÚJO, J. M. R.; RABONI, S. M. Enterovirus and Herpesviridae Family as etiologic agentes of lymphomonocytary meningitis, Southern Brazil. Arq. Neuropsiquiatr., v. 69, n. 3, p. 475-481, 2011. 
VERSTREPEN, W. A.; BRUYNSEELS, P.; MERTENS, A. H.; Evaluationn of a rapid realtime RT-PCR assay for detection of enterovirus RNA in cerebrospinal fluid specimens. $\mathbf{J}$. Clin. Virol., n. 25, p. S39-S43, 2002.

VLIET, K. E.; GLIMAKER, M.; LEBON, P.; KLAPPER, P. E.; TAYLOR, C. E.; CIARDI, M.; HAVOORT, H. G. A. M.; DIEPERSLOOT, R. J. A.; URTZ, J.; PEETERS, M. F.; CLEATOR, G. M.; LOON, A. M.; Multicenter Evaluation of the Amplicor Enterovirus PCR Test with Cerebrospinal Fluid from Patients with Aseptic Meningitis. J. Clin. Microbiol., v. 36, n. 9, p. 2652-2657, 1998.

WADELL, G. Molecular epidemiology of human adenoviruses. Curr. Top. Microbiol. Immunol., v. 110, p. 140-220, 1984.

WALKER, A. E.; LAWS, E. R.; UDVARHELYI, G. B.; Infectious and inflammatory involvement of the central nervous system. In: WALKER, A. E.; LAWS, E. R.; UDVARHELYI, G. B. The genesis of neuroscience. Ed. Thieme, 1998. p. 219-221.

WENG, K.; CHEN, L.; HUANG, L.; SHIN, S. Neural pathogenesis of enterovirus 71 infection. Microbes Infect., v. 12, p. 505-510, 2010.

WHITLEY, R. J. Herpes simplex encephalitis: adolescents and adults. Antiviral. Res., v. 71, p. 141-148, 2006.

WILD, P.; ENGELS, M.; SENN, C.; TOBLER, K.; ZIEGLER, U.; SCHRANER, E. M.; LOEPFE, E.; ACKERMANN, M.; MUELLER, M.; WALTHER, P. Impairment of nuclear pores in bovine herpesvirus 1-infected MDBK cells. J. Virol., v. 79, p. 1071-1083, 2005.

WOLD, W. S. M.; HORWITZ, M. S. Adenoviruses. In: KNIPE, D. M.; HOWLEY, P. M. Fields virology. $5^{\text {th }}$ ed. Philadelphia: Lippincott Williams \& Wilkins Publishers, 2007. p. 2395-2436.

ZAGARDO, M. T.; SHANHOLTZ, C. B.; ZOARSKI, G. H.; ROTHMAN, M. I. Rhombencephalitis Caused by Adenovirus: MR Imaging Appearance. AJNR Am. J. Neuroradiol., v. 19, p. 1901-1903, 1998.

ZUNT, J. R.; MARRA, C. M. Cerebrospinal fluid testing for the diagnosis of central nervous system infection. Neurol. Clin., v. 17, n. 4, p. 675-689, 1999. 